\title{
الثــــــورة والقـانـــــون
}

قر اءة في فكر علي عزت بيجوفيتش السياسي

د. أشتـرف محمـود أمـين

مدرس الفلسفة السياسية بقسم الفلسفة

كلية الآداب - جامعة الفيوم

$$
\text { يونيو IV }
$$


" أعتقد بأن عصر الثورات المسلحة انتهى إلى الأبد ، على الأقل

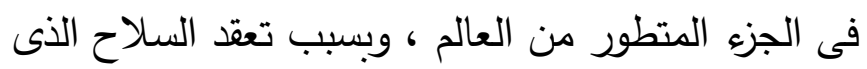

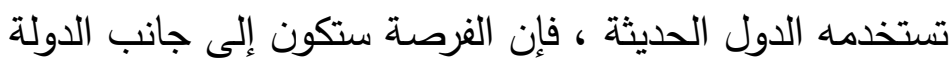

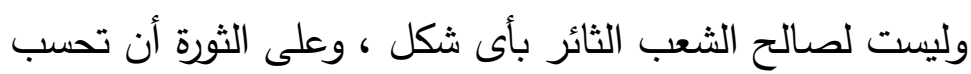
حساب ذلك وتتخذ طرق مغايرة أخرى غير السلاح كالعصيان

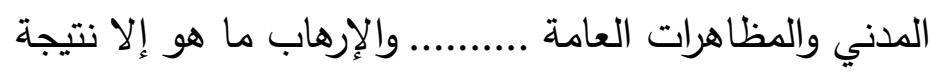
الضعف، وهو عمل غير أخلاقي وبلا ثمار؛ فهو غير أخلاقي

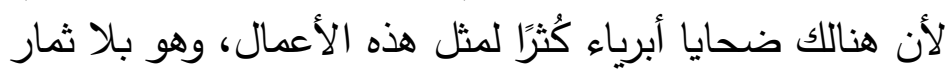

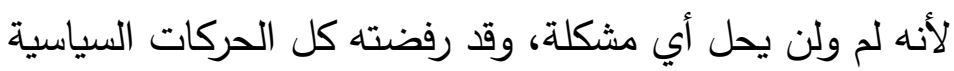

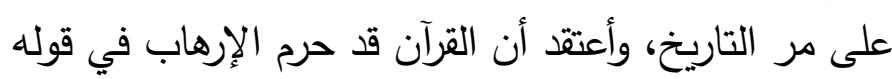

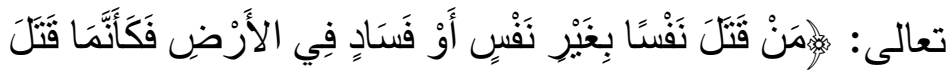

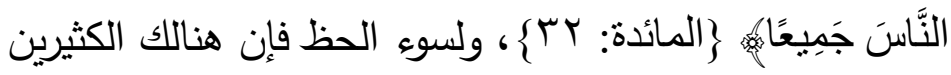

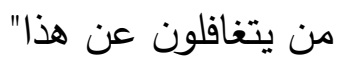

بيجوفيتش 
تمثل الفترة التي عاصرها بيجوفيتش من أخطر الفترات على دول البلقان؛ حيث أصبحت هذه الدول نهبًا للاستعمار والرجعية والتخلف والتعصب الذي أدى الدي

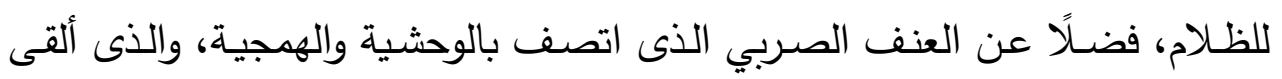
بظلاله على وطن بيجوفيتش في نهاية القرن العشرين (') لذا تحدث بيجوفيتش عن ثورة ليس لإسقاط نظام سياسي، بل لإسقاط نظام حياتي اجتماعي قيمي أخلاقي

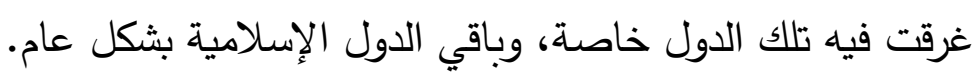

والثورة لغويًا تعني الغضـب والهياج؛ ففي لسـان العرب "ثار الثـيءُ ثَوزًاً

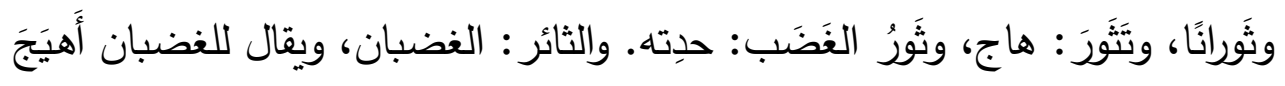

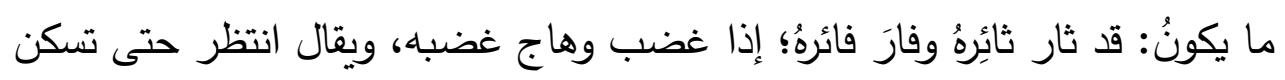

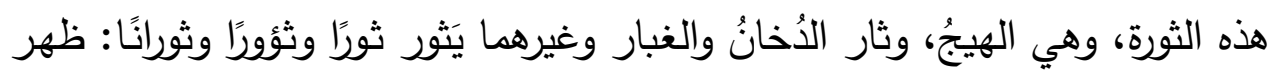

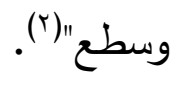

والثورة كمصطلح سياسي يعني الخروج على الوضـع الراهن وتغييره باندفاع يحركه عدم الرضا من أجل التطلع للأفضل؛ فهي فعل جماهيري شامل؛ فحين تتأزم الأوضاع السياسية والاقتصادية والاجتماعية وتصبح أحوال الناس لا تطاق، وعندما

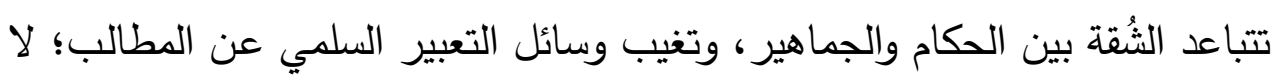

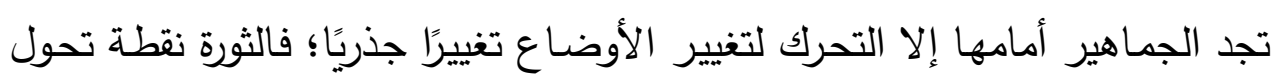
في حياة الثعوب على المستوى الاجتماعي والسياسي، والاقتصـادي، وبالتالي يكون هدف الثورة التحول للأفضل؛ لأن الثورة تعمل على الإطاحة بمن تعتبره الجماهير

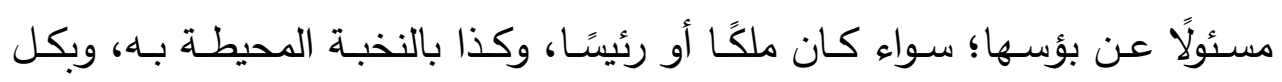

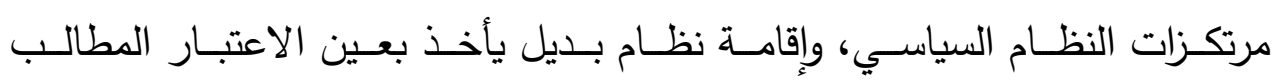

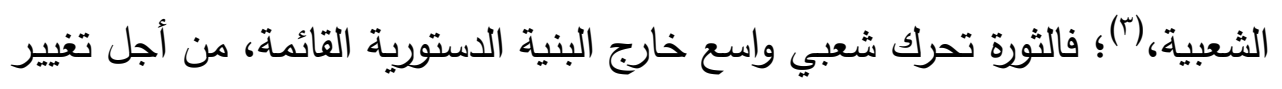
السياسـة القائمسة واستبدالها بسياسـة جديدة (عزمي بشارة: في الثورة والقابلية للثورة، 


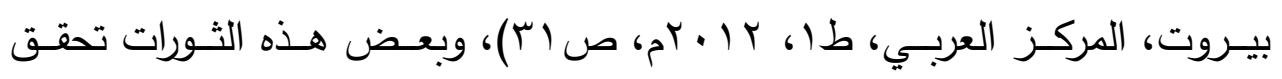
أهدافها، وبعضـها يفشل، وأخرى تتحرف عن مسارها.وفي بحثنا هذا نحاول تقديم معنى مغاير للثورة عند بيجوفيتش عن المعنى المتداول والمتعارف عليه الذي أشرنا إليـه آنفًا؛ فالثورة عند بيجوفيتش ثورة جوانيـة وليست برانيـة، ثورة تبـدأ من الداخل فئل

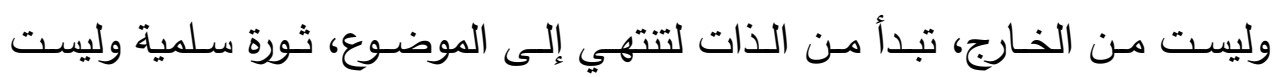
مسلحة، ومسن هنا كانت إثكالية البحث تدور حول تلك التساؤلات: هل يمكن أن أن تكون الثورة سلمية أم لابد أن تكون مسلحة يموت فيها كثير من الأبرياء؟ وهل الثورة تُختزل فقط في الخروج على الحاكم الجائر وحاشيته أم هناك ثورة تربويـة ودينية

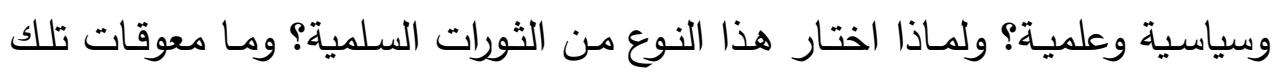
الثورة السلمية؟ ومـا علاقـة تلك الثورة بالقـانون؟ فهدف البحث إذن رصدـ المفهوم

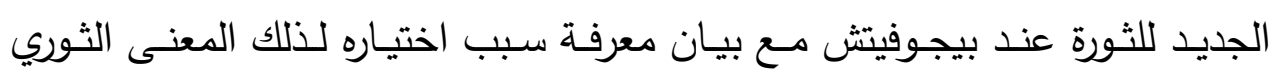

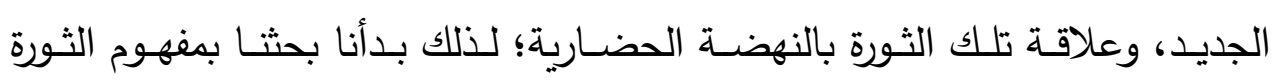

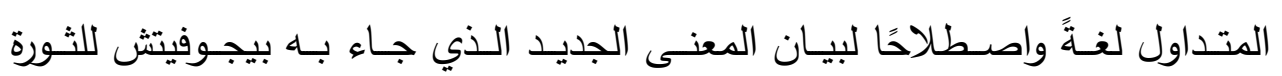
وعوائقها، وسوف نختم بحثنا بفكرة القانون وعلاقته بالثورة من حيث كونـه الخطوة التالية والضرورية للثورة؛ لحفاظه على على التظيم الجماعى، ومتطلبات الإنسان الأساسية؛ كالحريـة والحياة والملكية، ويقضى على الفوضى وعمليات النهب داخل

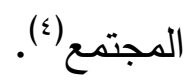

فلا قانون بدون إصلاح، ولا إصلاح بدون ثورة، فالعمل الثورى هو الطريقة

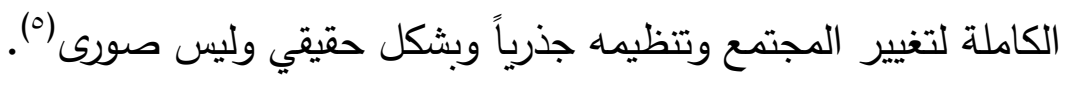
وهذا يتم مناقشته من خلال المحاور التالية: 1- الإطار التاريخي لفكر بيجوفيتش السياسي. r- مفهوم الثورة ودوافعها عند بيجوفيتش.

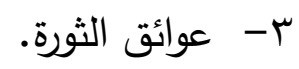




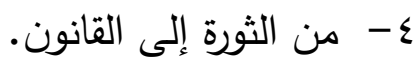

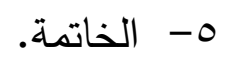

اولًا:- الإطار التاريخي لفكر بيحوفيتش السياسي:

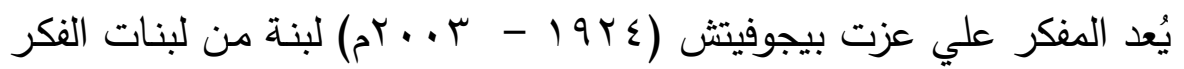
الإسـلامي المُشـرق على بـلاد البلقـان التي رزحت تحت الحُكم الثـيوعي عشـرات السنين (19 19 - ـ99 (م)، حتى قيض الله لها من يجدد لها أمر دينها، ويُبصرها بطريق التمكين والنجاح(؟) فقد ولد في مدينة بوسانسكي شاماتس أحد مدن البوسنة والهرسك، وانتقل إلى سراييفو في الثانية من عمره وفيها أتم دراسته حتى تخرج من ون

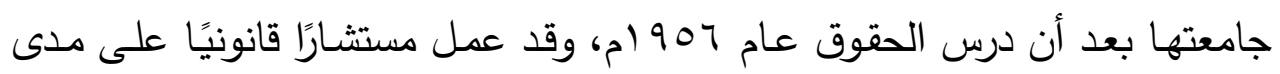
خمسة وعشرين عامًا، ثم اعتزل وتفرغ للبحث والكتابة؛ فكان واسـع الثقافة فقد اطلع

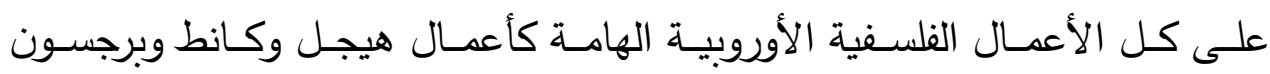
وشبنجلر، بجانب التزامـه الديني الذي يعود فيه الفضل لوالدته التي اعتتـ بتربيته

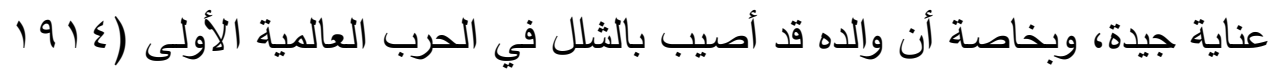

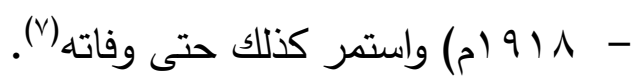

لقد رأي بيجوفيتش في الإسلام فكرة حية يجب أن تُحدث التغيير ؛ فانضم إلى

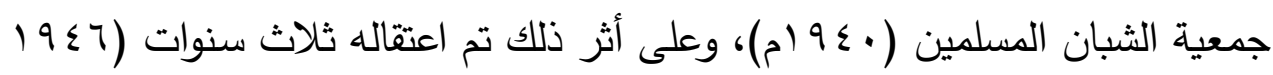

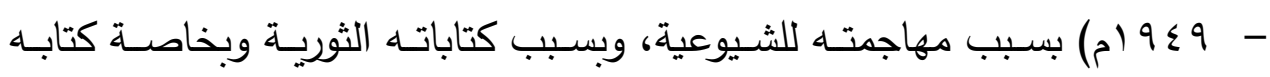
الأعظم (الإعلان الإسـلامي)، واعتقل مرة أخرى عام (سم9 (م) بتهمة التآمر ضد

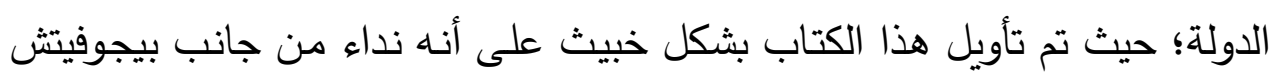
لإعادة تتظيم أوروبا وبنائها بشكل عام على مبادئ الشريعة الإسلامية، مع إعادة

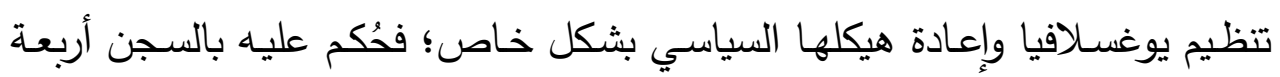
عشر عامًا، وقد نظر الإعلام الدولي المناهض للفكرة الإسلامية لهذه المحاكمة بعين

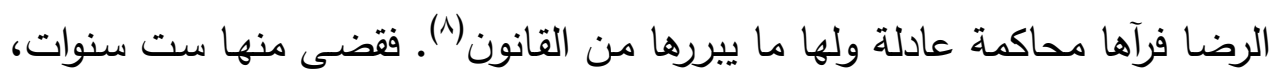


ثم أُعيدت محاكمتهـه تحت ضـغط منظمـات حقوق الإنسـان، التي أثبتـت للمحكمـة

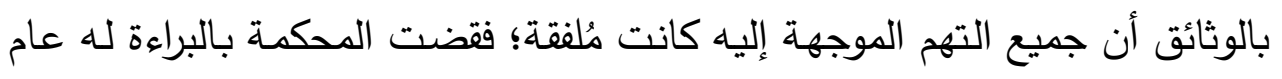
9 919 ام، وأراد تأسيس منظمة أو هيئة سياسية لمناصرة المسلمين في دول البلقان؛

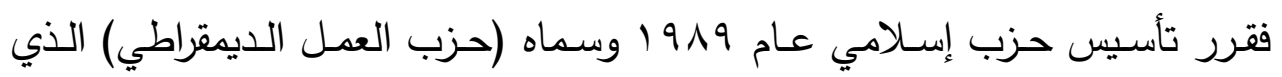
ترأسـا، وفي عام ( •99 (م) حصل الحزب على ستة وثمانين مقعدًا في انتخابات البرلمان بالبوسنة والهرسك، ثم تم انتخاب بيجوفيتش رئيسًا للبوسنة والهرسك باتفاق

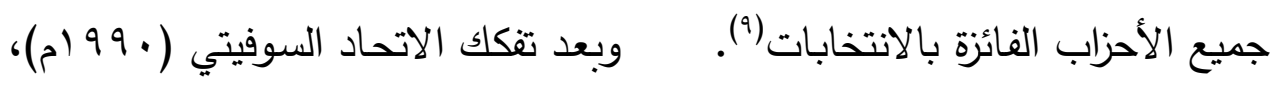
استقلت دول البلقان من قبضـة الحكم الشيوعي، وهذا قوبل بالرفض من المندوبين

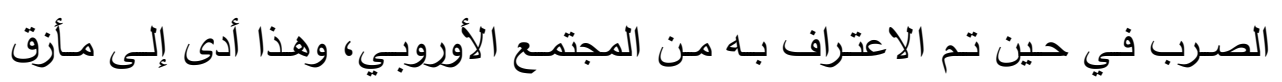

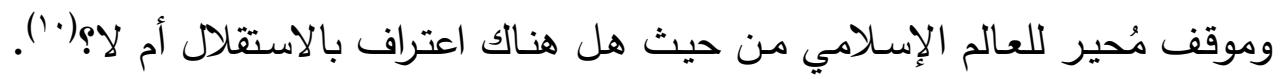
وعلى الرغم من ذلك ظهرت حركة القوميين الصرب ليهيمنوا على الحزب الثيوعي هي هائ

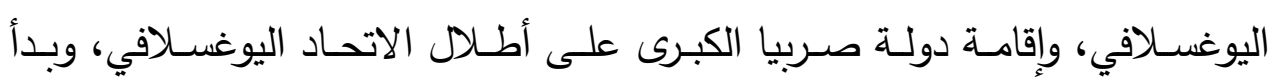
الصـرب في شـن حمـلات ضـــ الإســلام والمسـلمين في دول البلقـان لاستئصــال

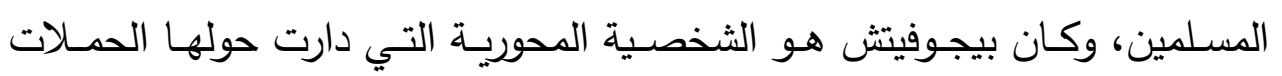
الصـربية، واتهــوه بالـدعوة للأصــولية الإســامية والتخطـيط لإقامـة دولــة إسـلامية بالبوسنة كنقطة انطلاق للسيطرة على يوغسلافيا وأسلمة بلاد البلقان، ثم الانقضـاض إلها

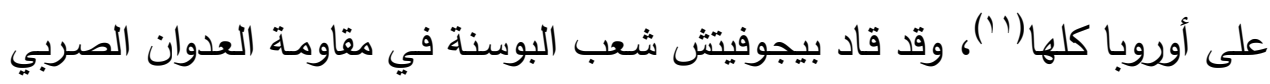
هذا الذي سقط على أثره ما لا يقل عن مئتي ألف مسلم من الرجال والنساء والثيوخ

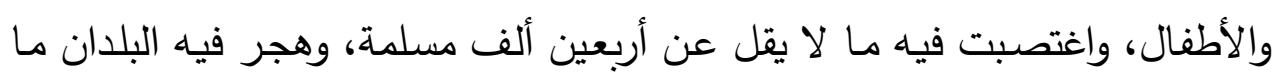
يقارب من مليون مُسلم، وبقدر ما كان لهذه الحرب من خسائر بشرية ومادية كثيرة للمسلمين إلا أنها جعلتهم يجتمعون تحت مظلة الدين، وتغيرت نظرتهم السطحية للدين على انـه مجموعـة مـن الطقوس والثـعائر (الإسـلام الثـكلي) إلى الاهتمـام

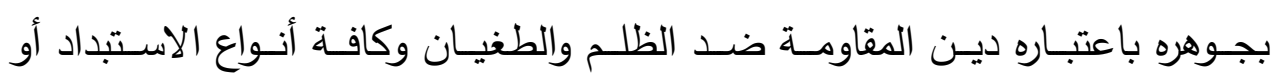

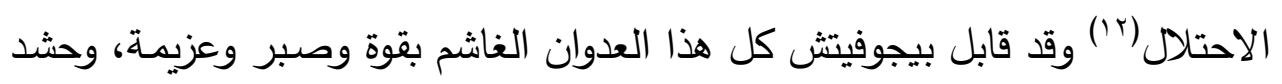


الدعم العسكري والمعنوي لشعبه حتى مكن الله لـه النصر والاستقلال باتفاقية دايتون

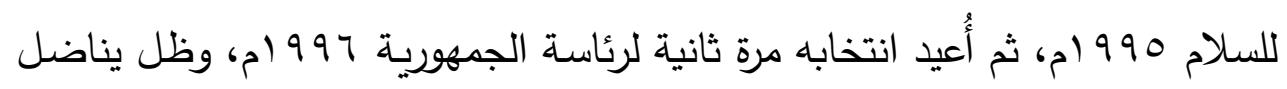

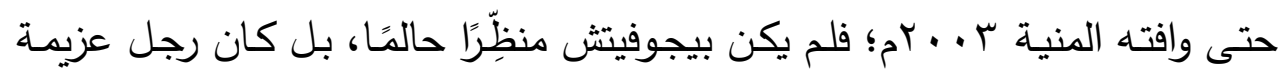
وعمل وقرار (r')، ومن أهم مؤلفاته:

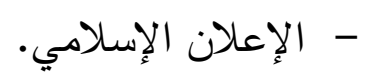

- الإسلام بين الشرق والغرب.

- عوائق النهضة الإسلامية (جزءان).

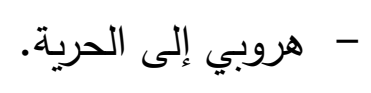

- سيرة ذاتية وأسئلة لا مفر منها.

\section{ثانياً:- - طيعة الثورة ودوافعها عند بيجوفيتش:}

الثورة عند بيجوفيتش ثورة دينية؛ أي تتطلق من الدين منهجًا ومضمونًا لإقامة مجتمع إسـلامي وسلطة إسـلامية؛ لذا كانت ذات شقين: شق تربوي وشق سياسي، يسبق الأول الثاني تاريخيًا أو على المستوى الزمني؛ فعند انحراف المجتمع وسيطرة

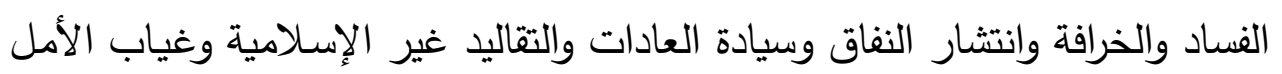

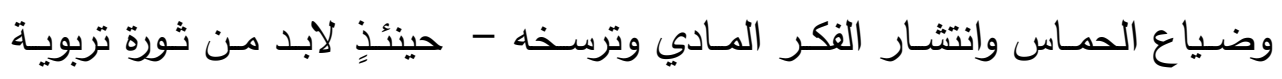
وإصلاح أخلاقي أولًا، إصلاح جواني خاص بالنفس يسبق الإصـلاح البراني الخاص

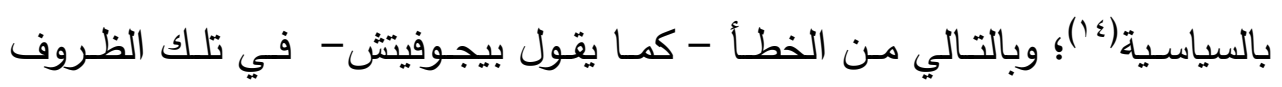
والأحوال الاعتقاد بأن "أقصر طريق للنظام الإسـلامي هو الاستيلاء على السلطة لئل

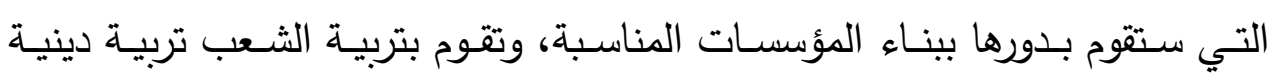
وأخلاقية وثقافية كمقدمة ضرورية لبناء مجتمع إسلامي؛ فهذه مجرد غواية؛ فالتاريخ لا يذكر لنا أي ثورة حقيقية جاءت عن طريق السلطة، وإنمـا عن طريق التربيـة، وكانت معنية في جوهرها بالدعوة الأخلاقية"(10). 
إن بدايـة الثـورة بشكل سياسـي كالإطاحسة بالسـلطة الحاكمـة؛ لإقامـة نظـام إسلامي سوف يؤدي لكثير من الإشكاليات والتساؤلات حول مصدر هذه السلطة من أين يأتي؟ ومن أي نـوع مـن الناس تتألف؟ ومـن سيُقيمها وينفذها؟ ومـن سيكبح

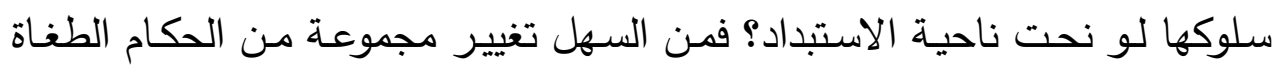

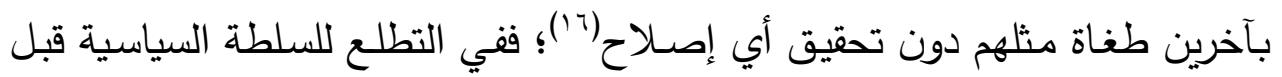

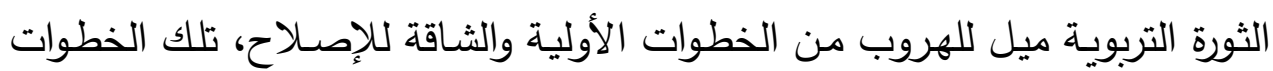
التي تتمثل في تربية الذات وتربية أفراد المجتمع؛ فالثورة الدينية الحقيقية التي تؤدي للإصـلاح والتغيير والصحوة هي التي تبدأ بالذات وتستهدف إيقاظ الناس أخلاقيًا؛ فتهتم بالمعايير الأخلاقية قبل الاهتمام بوحدة الأفكار والمصالح الحزبية، والثورة بهذا

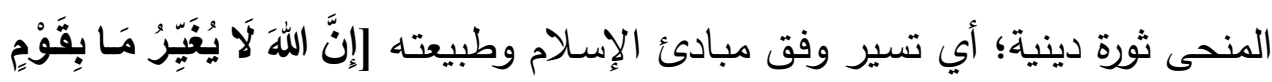

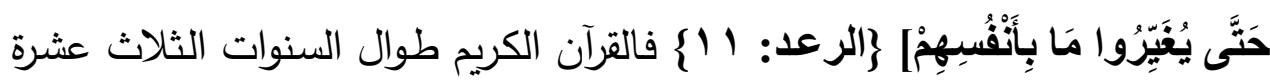
الأولى من الدعوة اقتصر في نقاشـه على قضـايا الإيمان والعقيدة وتأكيد المسئولية

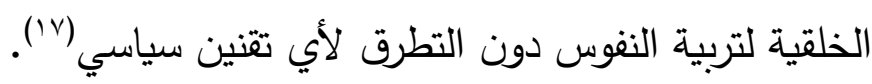
فالنظام الإسـلامي وحد بين التربية والسلطة، وبين الجماعة الروحية والدولة؛ لهذا فهو يفترض مجتمعًا إسلاميًا وحكمًا إسلاميًا، الأول هو مادة النظام، والثاني هو ولئي شكل النظام؛ لذلك كان المجتمع الإسلامي بدون سلطة إسلامية ناقصًا ومفتقرًا للقوة،

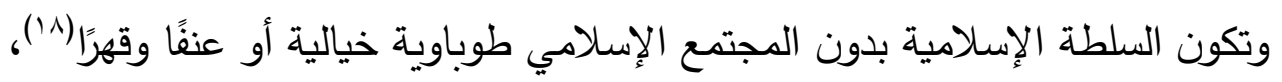

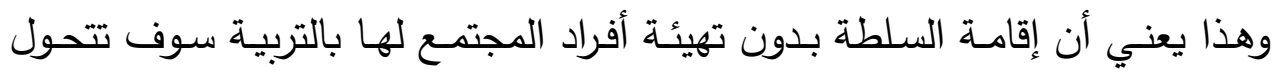

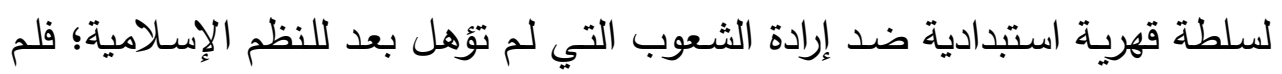
تلبث إلا أن تثور على تلك السلطة؛ ممّا يؤدي بالحاكم لاستخدام القوة والعنف أحيانًا - وهي مبادئ غير إسلامية- - لإرغامهم على قبول السلطة، أو يتركهم تحت اسم

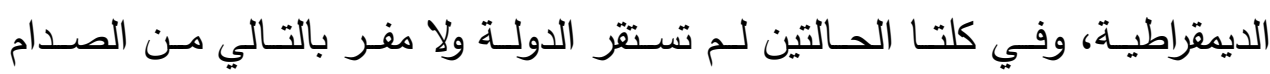

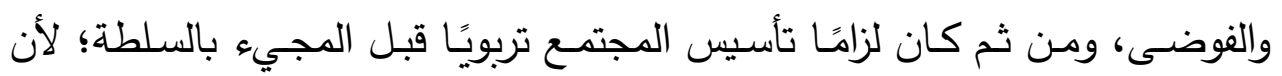
التسرع في تسلم السلطة خطأ. 
لذا يؤكد بيجوفيتش على الثوريين في الحقل الإسلامي عدم السعي للسلطة إلا

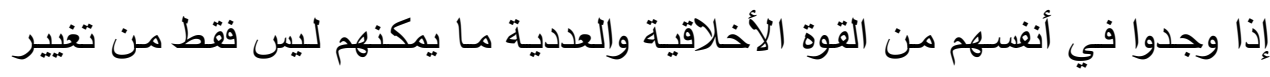

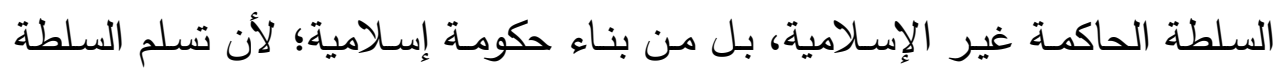

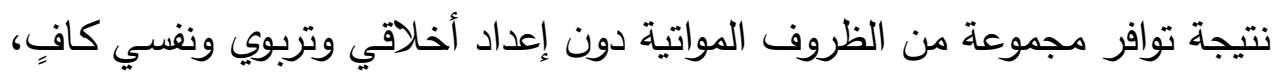

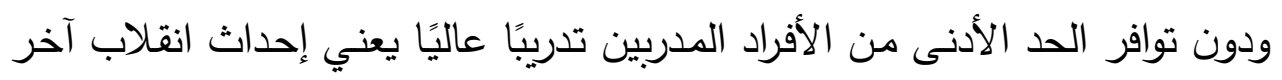

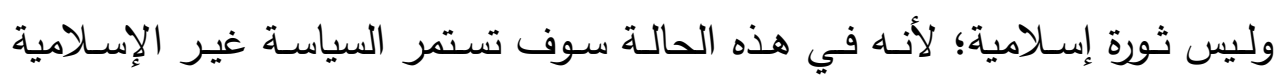

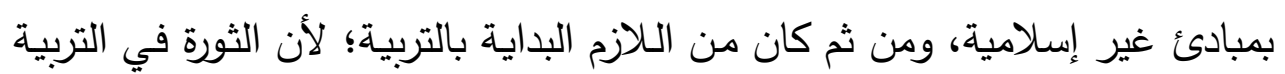

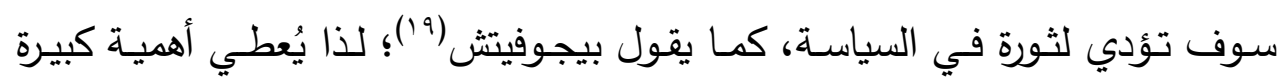

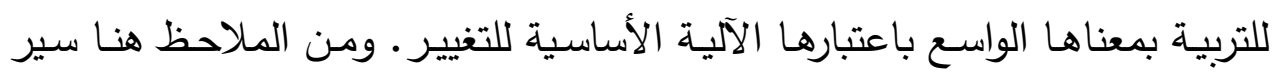

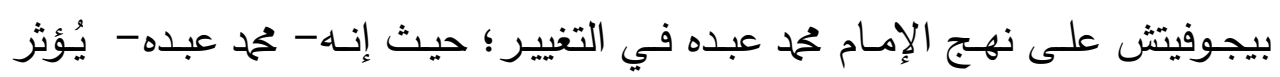

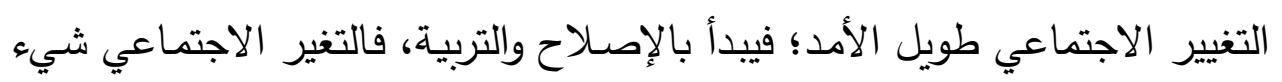

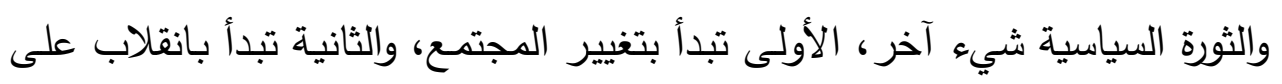

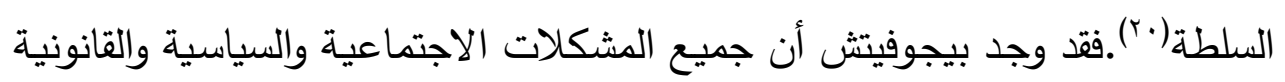

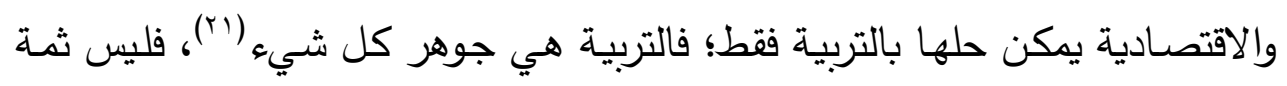

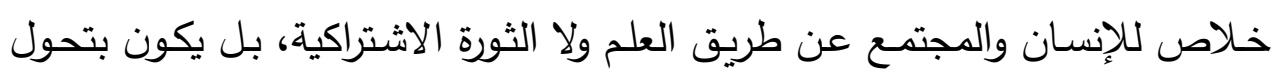

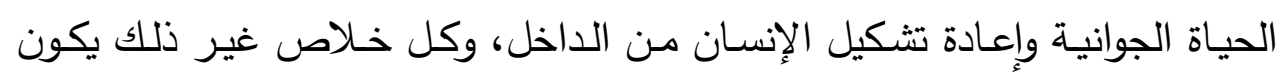

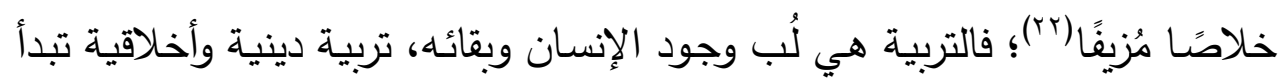

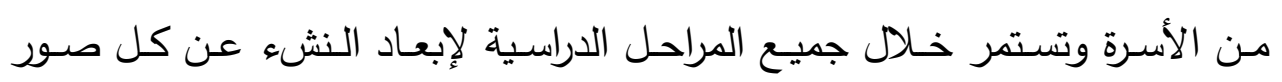

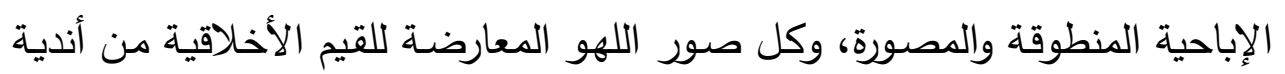

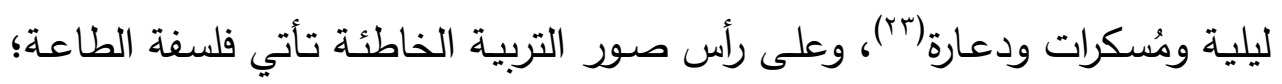

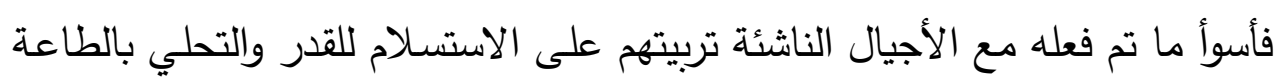

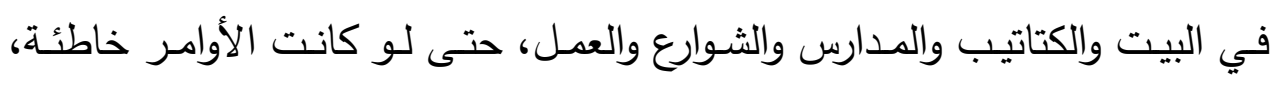

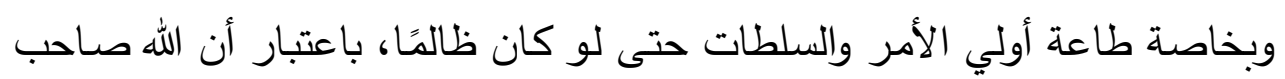

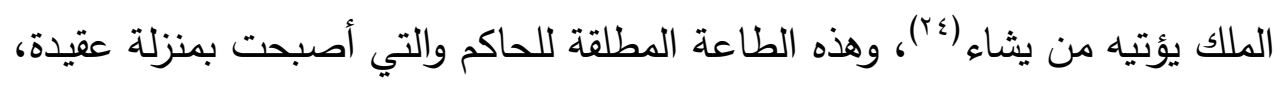


هي التي قادت تدريجيًا -ومن خـلال منحدر - إلى انهيار الحضـارة الإسـلامية(ror)، مـع أن الإسـلام ليس مصدرًا لفلسفة الطاعـة البئيسـة هذه؛ فهي فلسفة منـاهِ تُميت

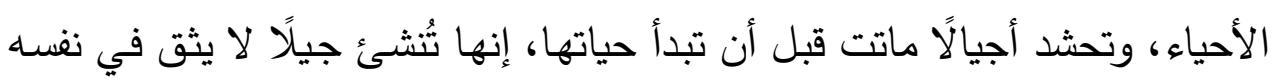

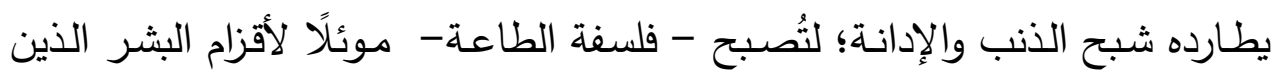
يهربون من الواقع الحي بحثًا عن الملجأ في الاستسلام السلبي ومواساة النفس، ومن

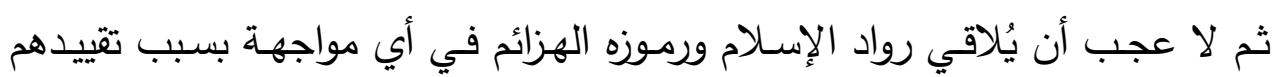
بفلسفة المناهي؛ فلا ينجحون في قيادة الشعوب لأنهم تربوا ليكونوا أتباعًا لا قادة(rrان. فالطاعـة في ثقافتتـا العربيـة فضـيلة الفضــائل، والضــــان الأكبـر للتماسـك والاستقرار في المجتمع، والدعامـة الأساسية لاستتباب الهدوء والسـلام بين الأفراد،

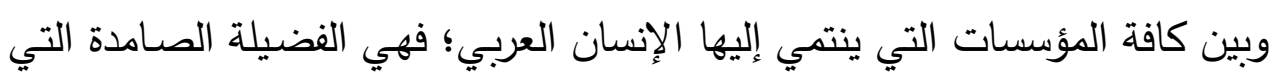

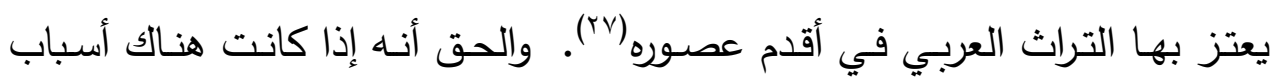
معنوية لتخلفنا وتراجعنا واستسلامنا أمام التحديات؛ فإن الطاعة تأتي على رأس هذه فه فئ الأسباب؛ فهي بدون تحفظ رذيلتنا الأولى؛ فتنشئة الإنسان العربي ترتكز في مراحلها المختلفة على تثبيت هذه القيمة الخلقية والاجتماعية حتى تصبح في نهاية الأمر الأر

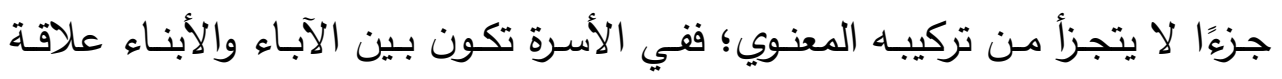

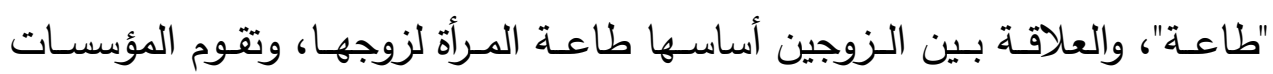

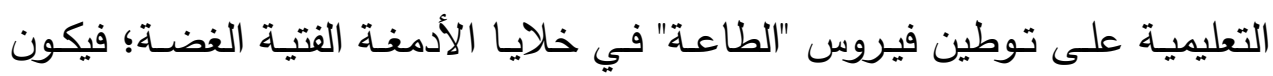
صـاحب التفوق هو الحافظ المُردد لما يُملى عليه من مقررات، وفي الحياة العملية تكون علاقة العمل مبنية في الأساس على مبدأ الطاعة بين الرئيس والمرووس، ولا يرتقي الموظف في منصبا إلا إن كان موظفًا مطيعًا، وفي ميدان السياسـة والحكم

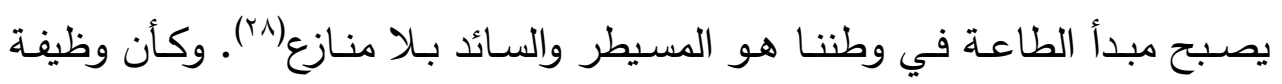
السلطان الرئيسية هي حمل رعيته على الطاعة، باعتباره هو المسئول أمام الله عن ون وكن

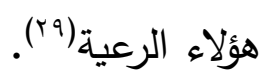


فالطاعة وباء ومرض عربي لا يفلت منه أحد؛ من أجل ذلك أوجب بيجوفيتش

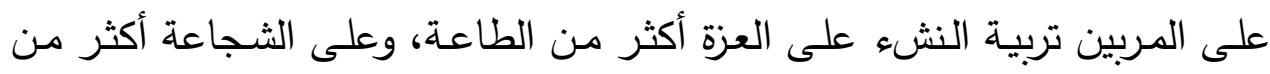

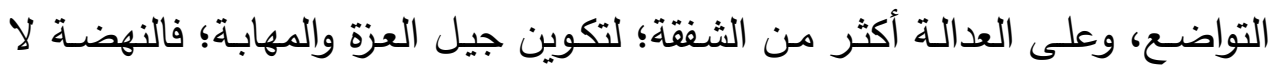
تتحقق على يد الوادعين المطيعين، بل على يد الثجعان الثائرين؛ فالثورة بهذا الثكل مطلب ديني لأن القرآن بريء من تربية الذل والانصياع والطاعة، ذلك القرآن الذي بلي

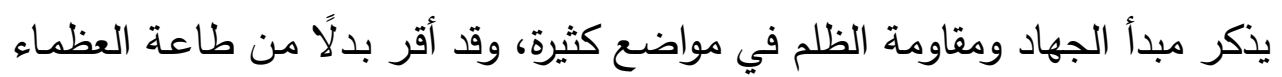
والسلاطين الزائفين، طاعة الله وحده، وبنى على هذه الطاعة المطلقة حريـة الإنسان

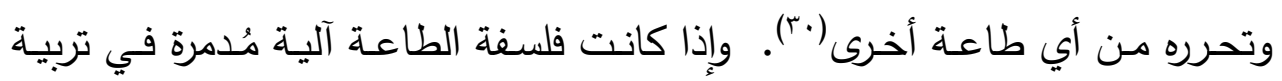
النشء- - يحذرنا منهـا بيجـوفيتش- فـذلك يخثى علـيهم مـن وسـائل الإعـلام الجماهيرية: المقروءة والمسموعة والمرئية، الواقعة في أيدي المارقين والمنحلين الذين

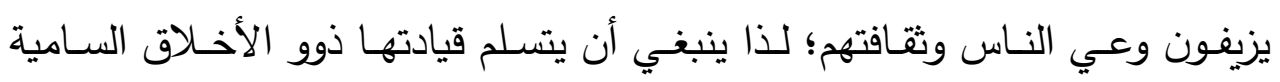

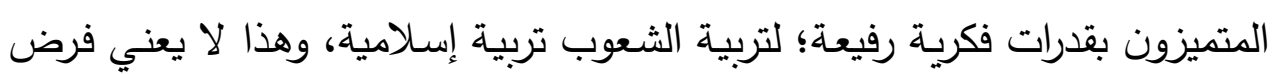

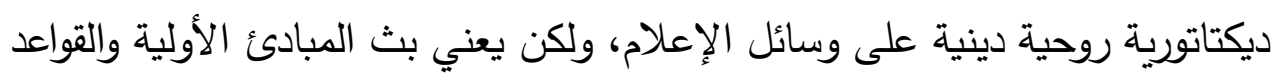

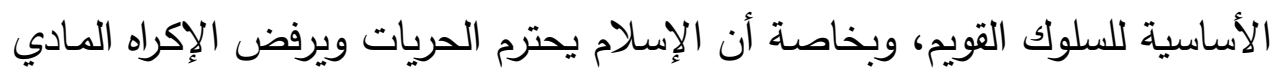

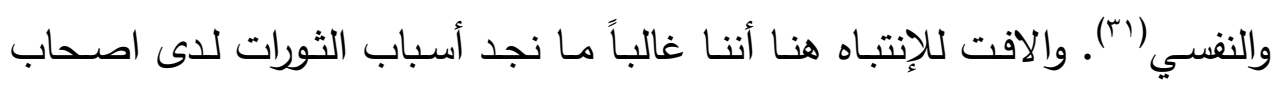
الفكر السياسي تعود إلى الأوضاع السياسية؛ كالدوافع الأيدولوجية المرتبطة بمفاهيم

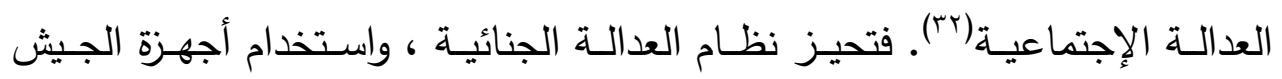

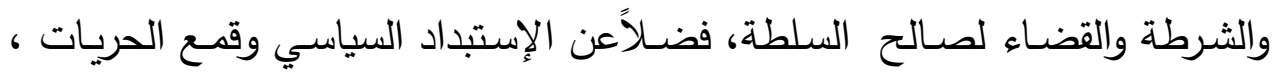

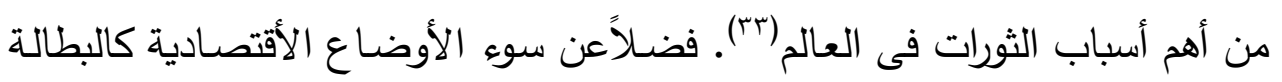

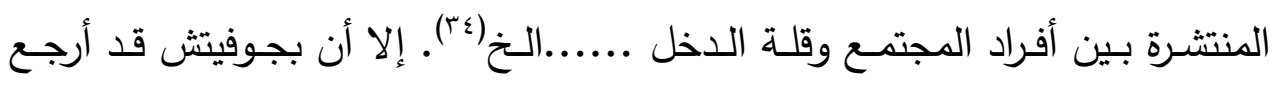
دوافع الثورة إلى وضعية التعليم ووضعية المرأة، فدوافع بيجوفيتش للبدء بالثورة التربوية تعود في المقـام الأول إلى تـدهور وضـعية التعليم ووضـعية المـرأة وإصـابتهما بـالجمود والرجعية في عالمنا الإسلامي؛ فلابد من إصلاحهما لتحقق الثثرة مسارها الصحيح. 


\section{وضعية التعليم:}

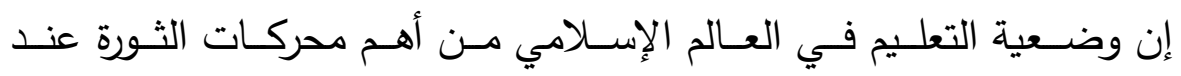
بيجوفيتش، حيث إنه لا يوجد في دولة مسلمة واحدة نظام تعليمي مُعد إعدادًا مناسبًا

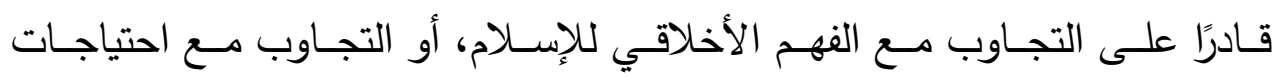

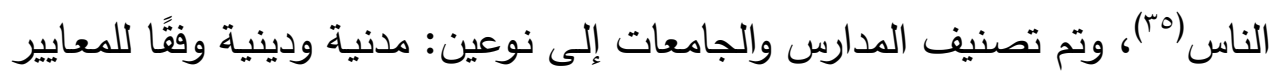

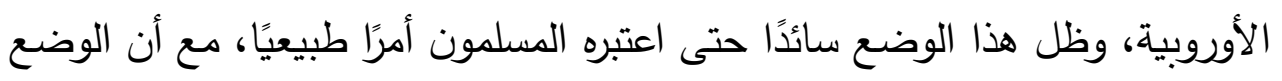

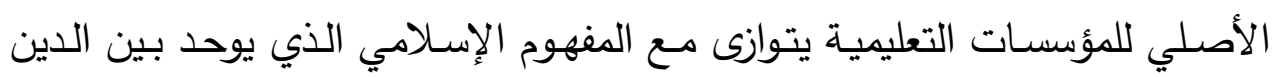

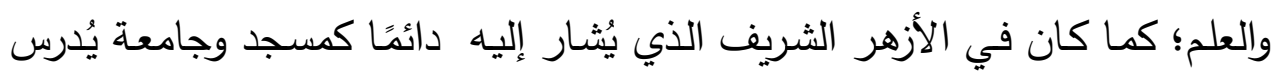

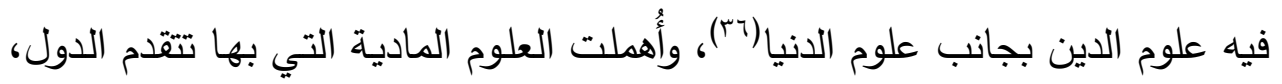
حيث توزعت المدارس العلمية على أربعة موضوعات لاهوتية: الحديث والفقه وعلم الكلام والتفسير، وتم نسيان النص القرآني على تأمل الطبيعة، ذلك التأمل الذي يُنتج النظريات العلميـة، وبذلك ضـاعت في طوايا النسيان الأعمال الأصيلة التي كانت تصنيان

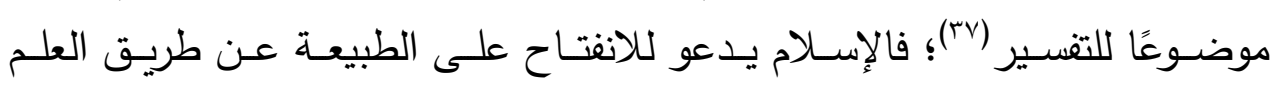

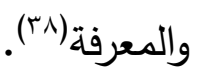

ويُرجع بيجوفيتش تردي أوضـاع التعليم إلى عاملين أولهما: عدم توافر قادة متعلمين تعليمًا صحيحًا فعالًا، حيث توافر اللشعوب الإسـلامية نوعان من المُعلمين وهما: الجهال والمتعلمون تعليمًا خطأ، وكلاهما ضـار ، والعامل الثاني والأهم وهو هيمنة السلطة السياسية وإهمالها لتلك المؤسسة بالغة الحساسية في أي مجتمع (وَ)؛ لأن مصـلحة الحكام في جهل الثـعوب، حيث يدفعهم هذا الجهل لتحمل طغيـان الحُكام والخوف منهم وتملقهم؛ لذا لا يسعى الحكام لتعليم شعوبهم (•؛). والحق أن الاستبداد والعلم لا يجتمعـان؛ فالجهل يعد سببًا رئيسيًا للاستبداد؛ فالجهالة أول أنصار الاستبداد وأبرز أعوانه بالإضـافة إلى جنوده ورجال الدين؛ فإذاذيا

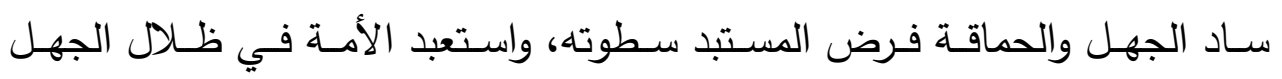

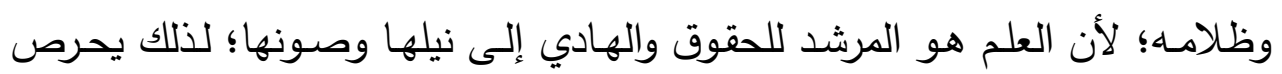


الحاكم المستبد على أن يظل الناس في جهل مستمر (1). فالعلم نور وهو يريد أن

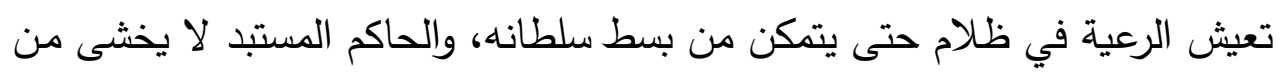

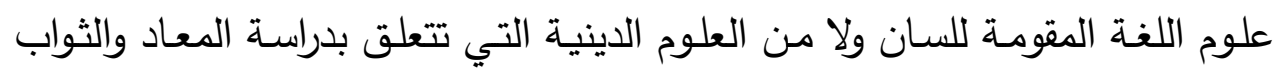

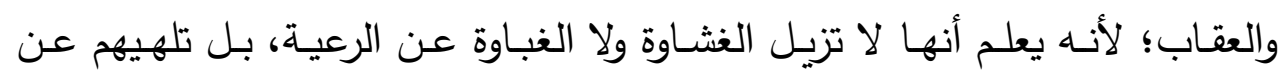

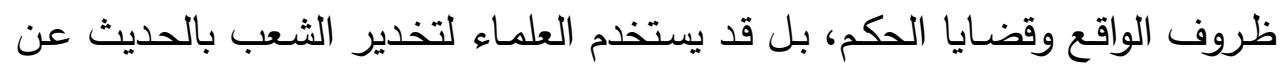

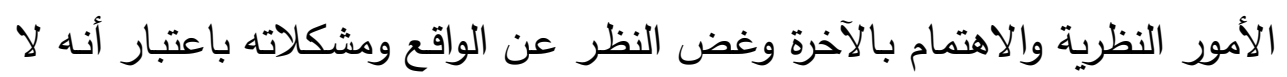

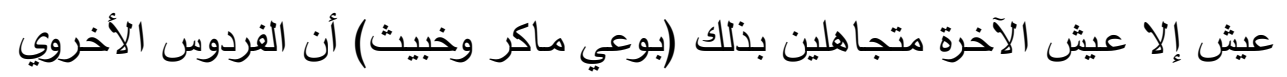

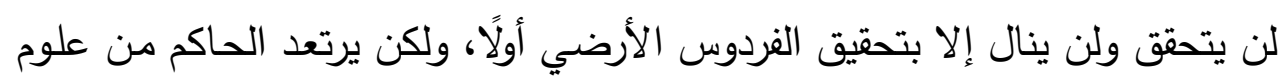

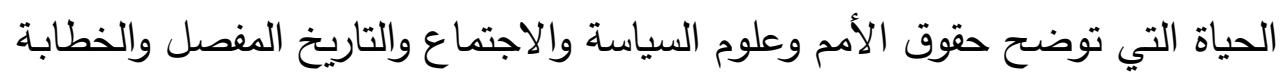

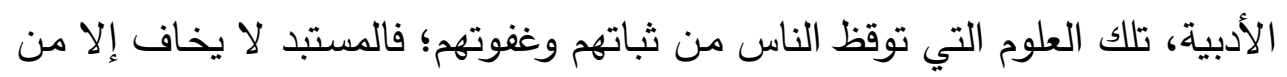

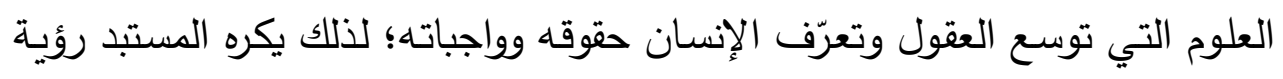

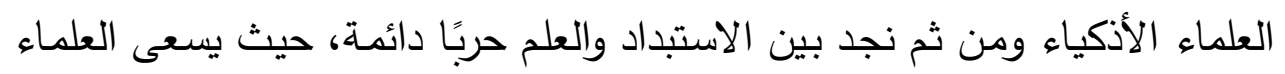

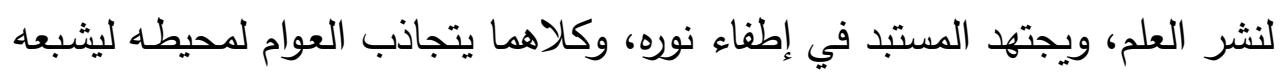

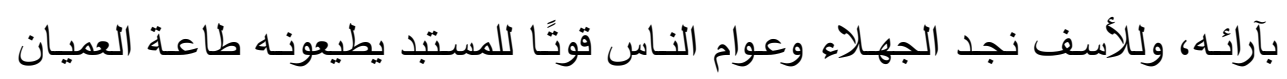

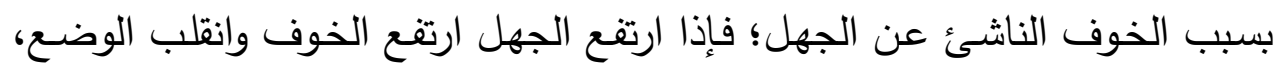

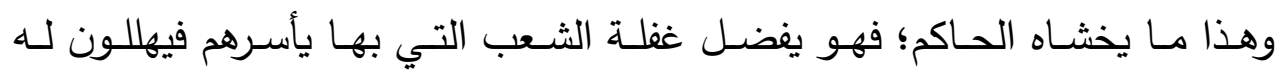

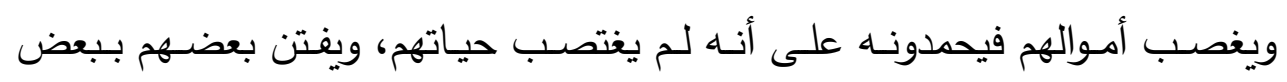

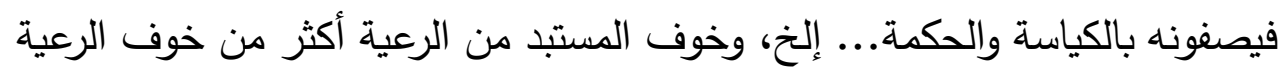

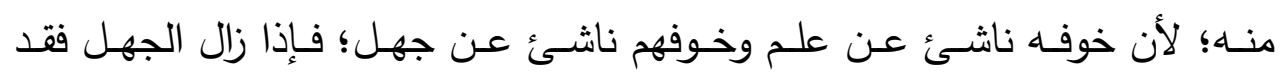

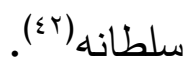
ومسن ثم كانت النتيجـة- - بزعم بيجوفيتش- - ترك الكثير مـ المؤسسـات

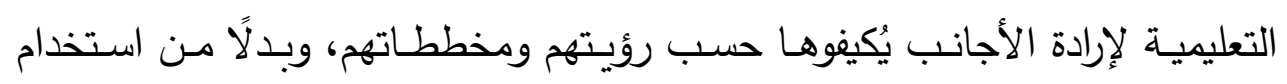

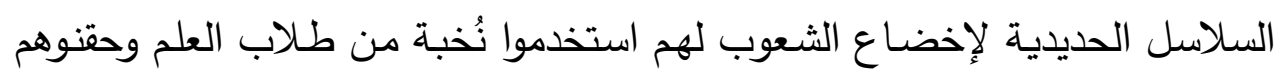

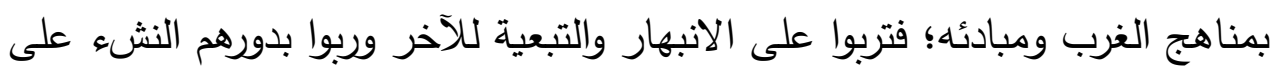


ذلك وفرضوا أنظمة تعليمية على الثعب باسم التطور الذي جرى وفق تقليد أعمى لنمط الحياة الغربية؛ فساقته بذلك إلى حالة عقدة النقص النفسية وشل قدراته على لى

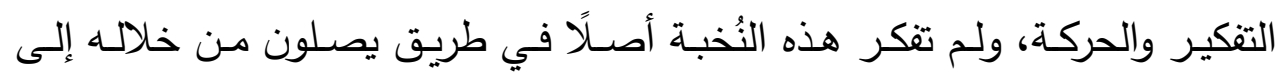
شعوبهم والتعرف على طموحهم ومصالحهم الحقيقية، بل كانوا أجانب في بلادهم بما

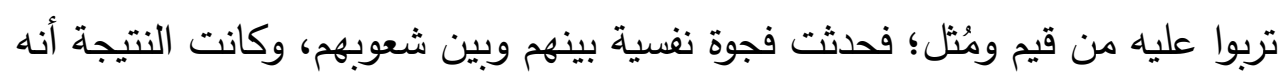
لـم يُصـبح التعليم مصـدرًا للإصــلاح والتمـرد والمقاومـة، بـل صـار مصــرًا للتبعيـة

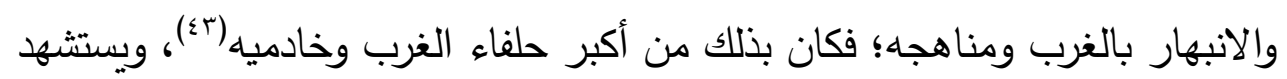

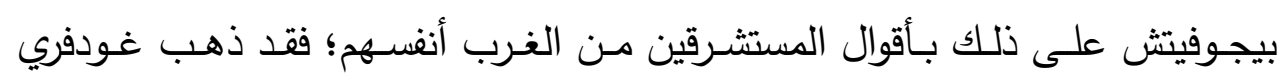
يانسن. موضـحًا خطة الغرب في تدمير المؤسسات التعليمية ومحو تراثها وثقافتها قائًاً: "إن إسـتراتيجية الغزو الغربـي تكمـن في هدم النظـام التعليمسي القـائم سـواء بمسخه نهائيًا أو باستبداله كليًا وإحـلال النظام التعليمي الغربي محلهـ....... وذلك فئك بهدف زرع التفرقة في روح المجتمع بتنشئة نخبة مثقفة موغلـة في أقصى درجات

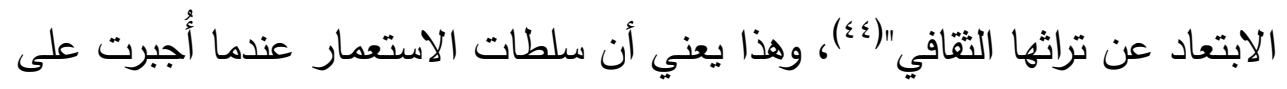
تسليم السلطة السياسية سـمتها لتلاميذها الروحيين الغربـاء عن شعوبهم وتراثهر الإسـلامي، ومـن هنـا أصبحت النظم التعليميـة موروثة عن الاستعمار وهي أكبر

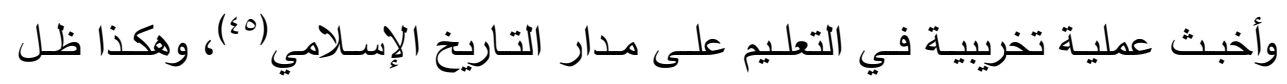

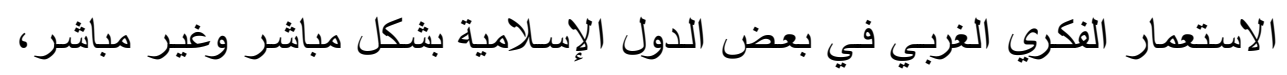

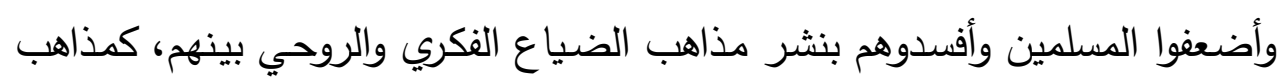

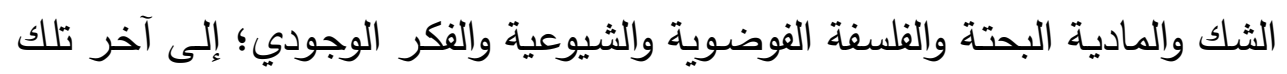

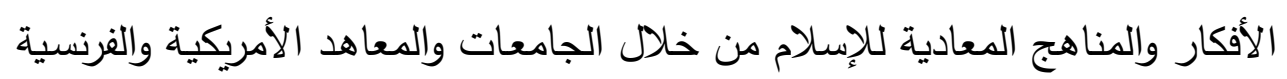
والإنجليزية المنتشرة في عواصم العالم الإسلامي (تء).

ولا يرفض بيجوفيتش التأثر بالغرب في المجال العلمي بشكل كلي، بل يؤكد

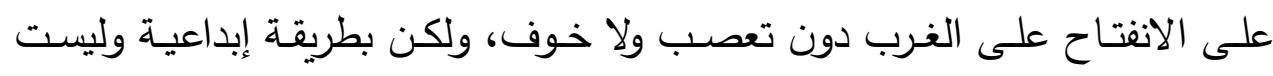

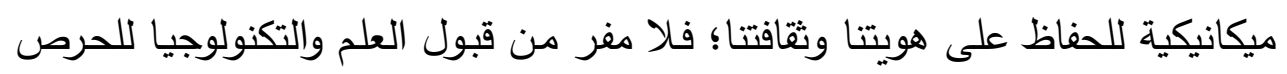




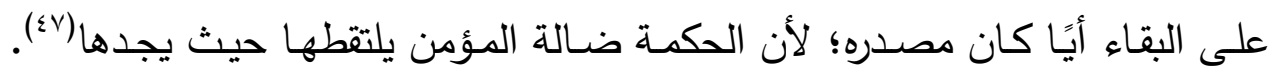
وليس أدل على ذلك من أن بيجوفيتش ذاته كان متوافقًا ومتأثرًا وقارئًا للعلوم الفرنسية والتاريخ البريطاني والأدب الروسي، وقد تأثر بكل من فرويد وماركس وإنجلز وكارل

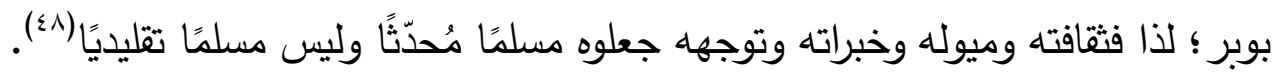

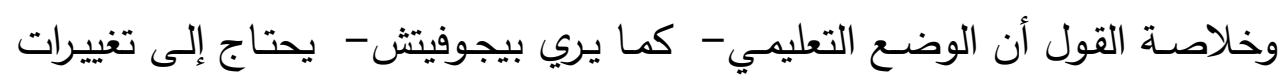

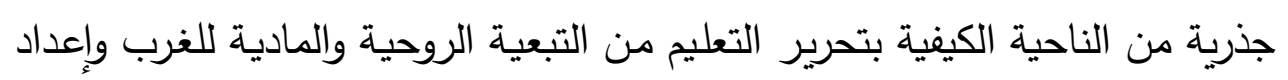
قادة مبدعين في هذا المجال، وتغيـرات جذريـة مـن الناحيـة الكميـة بتجديــ العلوم الدينية وازدهار العلوم المادية، مع خلق الظروف المواتية لإتاحة التعليم لجميع فئات

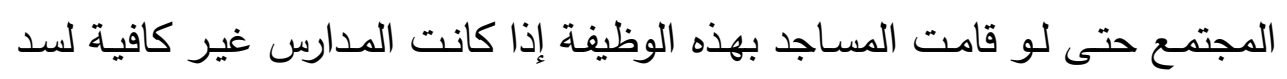

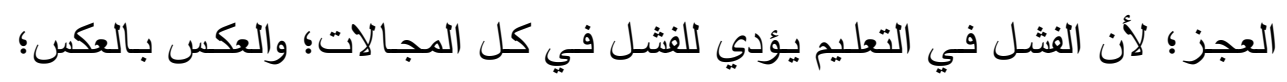

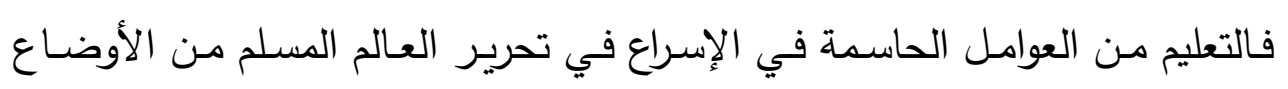

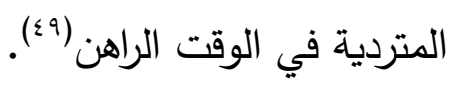

\section{وضعية المرأة:}

إن وضع المرأة اليوم في المجتمع الإسلامي - كما يقول بيجوفيتش- لامة يطابق الوضع الذي يمنحها الإسلام من حقوقهن المشروعة الخاصة بالأمومة والتعليم والمعاملة الحسنة وما يخص وضعها داخل الأسرة من ناحية علاقتها بالرجل خصوصًا في حالة الطلاق وحالة تعدد الزوجات؛ فوضع المرأة المسلمة اليوم يعود في المقام الأول لتفسير الثريعة حسب العرف والذوق والمستوى الأخلاقي للبيئة؛ فالإسلام واحد ولكن المشكلة في الفهم والتفسير والتطبيق حسب البيئات، فمنها ما هو متخلف ومنها ما هو متحضر ومتعلم(0)؛ فالتأثير الرئيس في وضع المرأة إذن والن يأتي من قِبل التراث والمستوى الثقافي والتربوي ومستوى المرأة التعليمي، ويتعلق جزئيًا بالقوانين المنظمة لشئونها(1)؛ وبالتالي فإشكالية وضعية المرأة في العالم الإسلامي لا تعود للنص المقدس، بل في كيفية التعامل معه، وهذا إن دل على شيء فإنما يدل على أن الإسلام باعتباره نمطًا حيويًا للحياة يشجعنا على أن نُخدل 
فيه ما نريد نحن وأن نكون عليه، وما تصبو عقولنا وقلوبنا إليه، على أن يكون ذلك تحت مظلة أحكام الإسلام، وعلى هذا "وانطلاقًا من مقاصد الأحكام الشرعية يمكننا في المستقبل تحقيق وضع المرأة المسلمة بشكل يستجيب لاحترام إنسانيتها ويتناسب

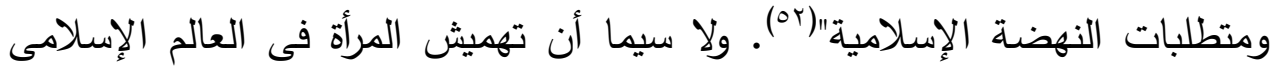
أدى إلى خلق انطباعاً خاطئاً لدى الغرب فى زعمهم أن جميع النساء فى العالم الإسلامى غير مؤهلين للمشاركة فى الأدوار الرئيسية فى المجتمع والدولة|(or). لعدم

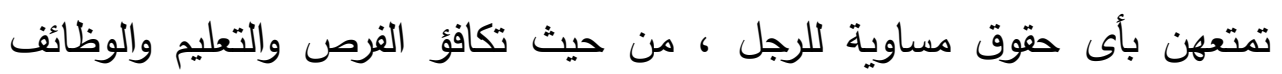
والحقوق السياسية وقوانين الأسرة، وخاصة تعدد الزوجات واحتكار العصمة للرجل دون المرأة(\&). لذا جاء تصنيف منطقة العالم العربى والإسلامى من قِبل الأمم المتحدة والإتحاد البرلمانى الدولى، على أنها أدنى منطقة فى العالم فيما يخص وضعية المرأة فى المجال الإجتماعى والسياسي، وخاصة المشاركة البرلمانية كوالسبب فى ذلك حسب زعمهم سوء الثقافة العربية التى يُهيمن عليها الذكورية والأبوية، وتخضع للعادات والتقاليد القبلية الخاطئة، والغير موضوعية، التى ترى أن أن

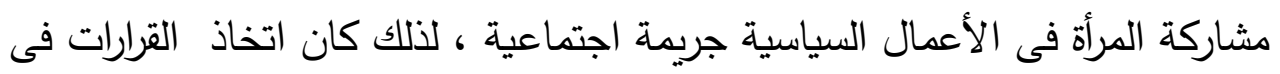

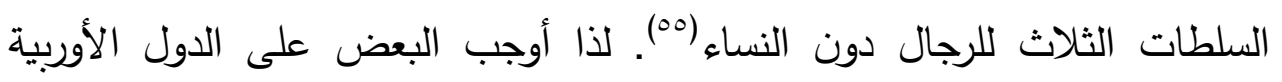
الكبرى وخاصة الولايات المتحدة التدخل فى تلك المنطقة للنهوض بالمرأة والمطالبة

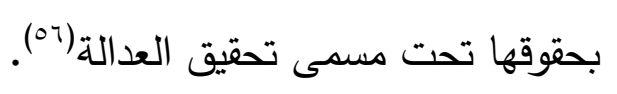

وقد نـاقش بيجـوفيتش هذه الأوضـاع بكل موضـوعية فقبـل بعضـها ورفض هـا

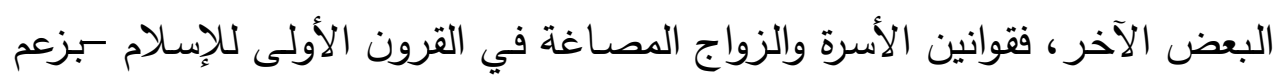
بيجوفيتش - تحتاج إلى مراجعة بما يتلاءم مع متطلبات العصر ؛ فيكون الاتجاه نحو

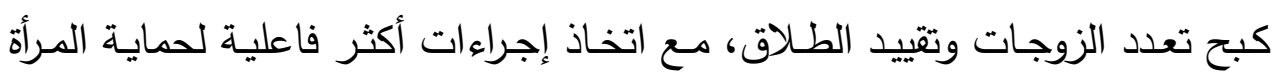

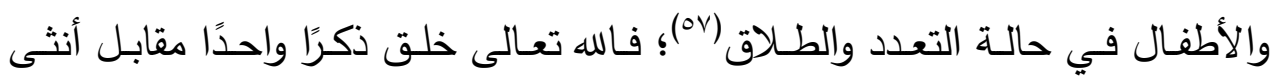
واحدة، وأودع هذه المعادلة في قوانين الطبيعة، ولا تتغير هذه المعادلة إلا في حالات

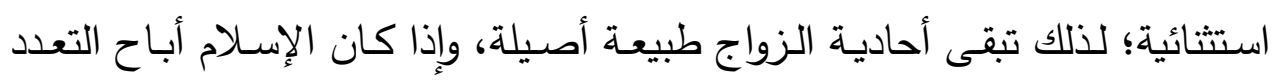


وذلك لأن الإسلام حرم الزنا، وبالتالي رفض أن تكون الأحادية بشكل نظري كاذب كالنمط الغربي الأوروبي الذي انتشر فيه التعدد السري بسبب رفض المسيحية لتعدد

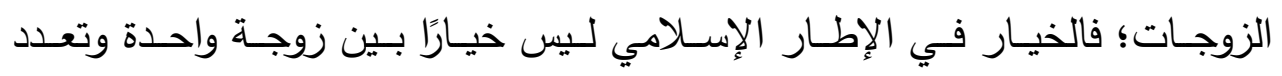
الزوجات، بل خيار بين حالات تعدد مشروعة ومعدودة وبين التعدد السري غير لروبر المشروع والمنتشر في الغرب والذي لا يمكن القضساء عليه إلا بذهاب الغرب ذاته،

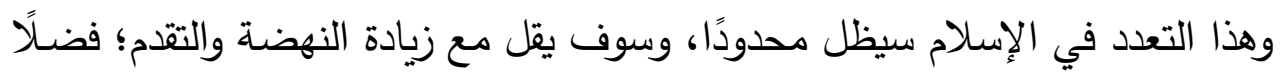
عن أن الإسلام لم يمنع الزوجة من الاشتراط على من يتزوجها بعدم التعدد ولا يكون

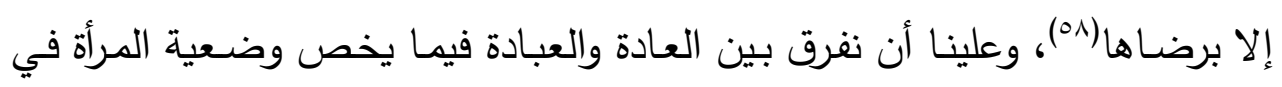

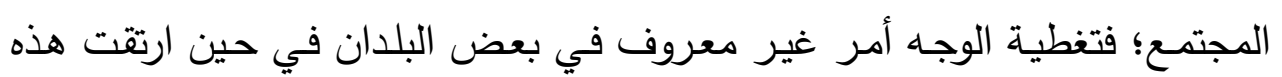

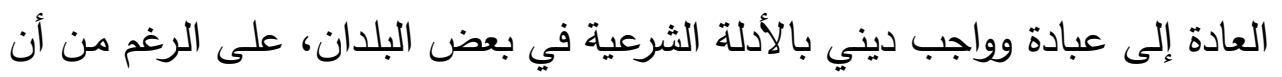
المرأة لم تكن تغطي وجهها في عهد النبي ، وأول من أدخل هذه الموضـة الجديدة (عاليـة أخت هـارون الرشيد)؛ مـع العلم بعدم أهليتها لإضـافة أي شـيء للأحكـام الثرعية، وهكذا الحال فيما يخص فصل الرجال عن النساء قد تكون عادة اقتبسها المسلمون من البيزنطيين في عهد الخليفة الوليد الثاني، وبخاصـة أن هذه العادة لم الم تظهر بوضسوح إلا في القرن العاشر الميلادي؛ أي بعد مئتين وخمسين عامًا من فن فئن

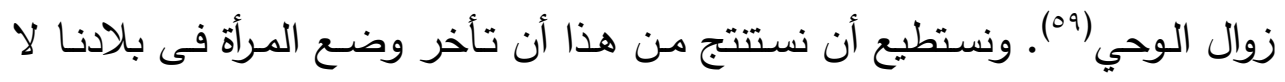
يعود للشريعة بل يعود فى المقام الأول إلى بُطئ التغيرات السياسية لوضـع المرأة

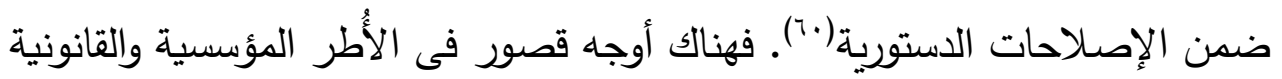
تعوق المرأة عن المشاركة فى الأدوار السياسية والإجتماعية(1).

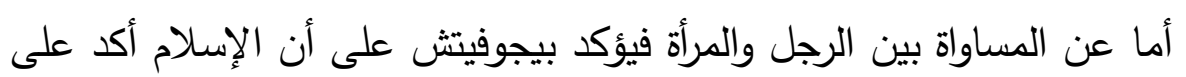
إبراز القيمة المتساوية بينهما في الالتزامات الدينية والأخلاقية وتحمل المسئولية تجاه

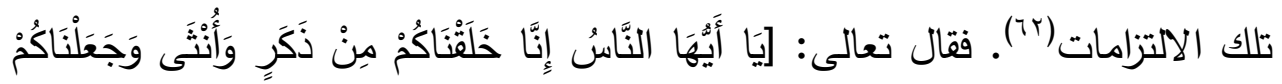

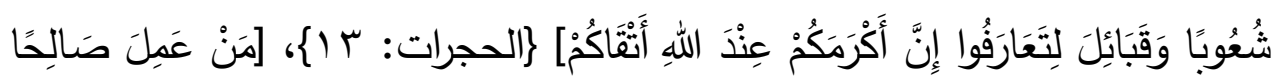

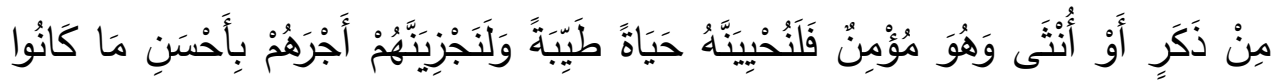


يَعْمَلُونَ] \}النحل: 9V\{؛ فالمرأة شخصية إنسانية ذات قيمة تتحمل واجبات أخلاقية وجمالية وإنسانية؛ فالحقيقة التي يجب الانتباه إليها: أن الواجبات التي يفرضها القرآن مساوية تمامًا في حق الرجل والمرأة؛ فلا فرق بينهما في أداء الواجب وتحمل المسئولية؛ فالمسئولية متساوية ما دامت القيمة متساوية، وكل قانون يجعل القيمة أساس المسئولية(זٓ)، إلا أن هذا لا يعني المساواة المطلقة بين الجنسين بالمعنى الأوروبي؛ ذلك المعنى الذي جرد المرأة من وظيفة الأمومة وهي وظيفتها الأساسية وحوّلها إلى شيء للاستمتاع به أو عبادته؛ فسلبها بذلك موضع التهن التقدير

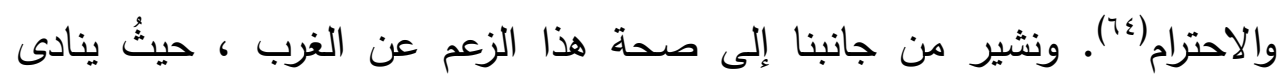
بمساواة المرأة بالرجل فلى العالم الإسلامى، فى كافة الحقوق سواء التعليمية أو

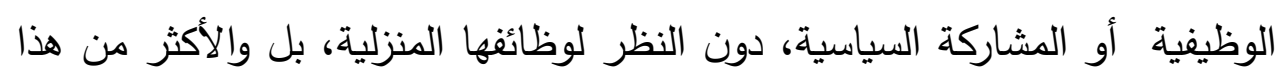

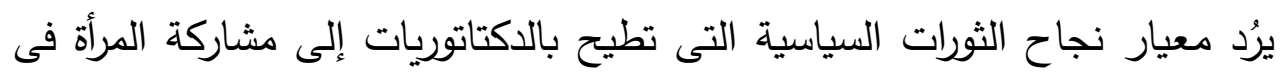

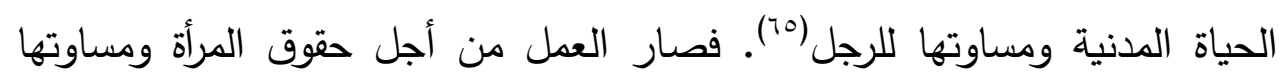
للرجل جزء لا يتجزء من النضال من أجل الديمقراطية(T؟ا).

وهذا ما رفضـا بيجوفيتش مؤكداً على أن المساواة بينها لا تتعلق بالتساوي

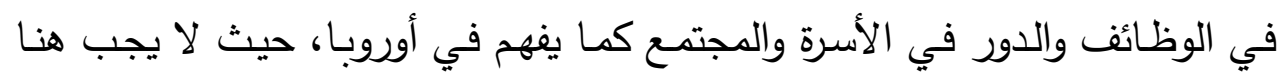

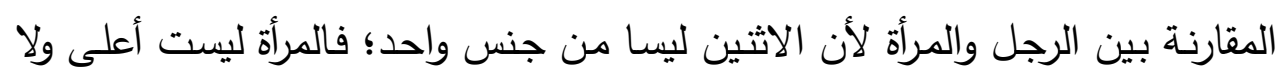

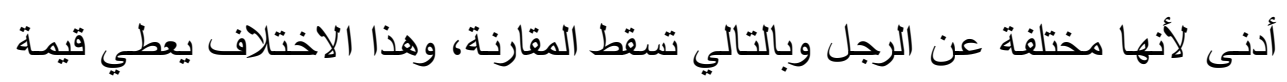
خاصة لأحدهما بالنسبة للآخر ، وهذا يتضح مثلًا في الفوارق بينهما في الذكاء؛ فقد وند دلت الاختبارات أن الفوارق تتعلق بكيفيـة الذكاء لا بمستوى الذكاء؛ فذكاء الرجل

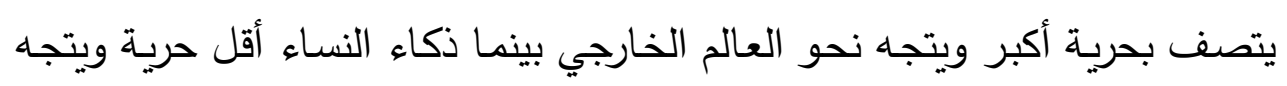

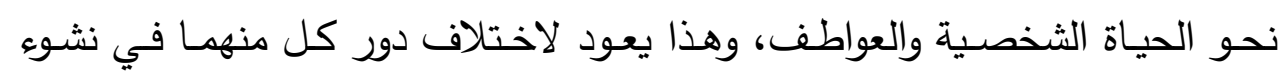

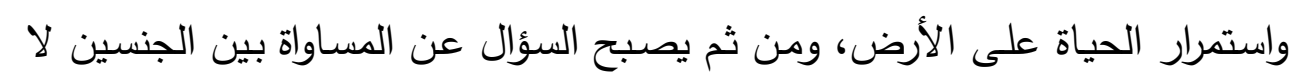

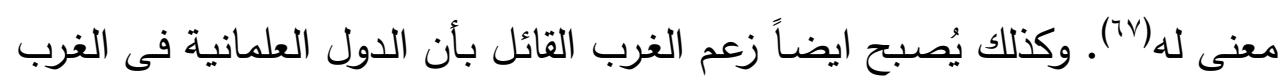


تحقق مكاسب سياسية وملموسـة للمرأة أكثر من الدول الإسـلامية زعم لا قيمـة لـه، لعدم وجود تماثل بين العالم الغربى والإسلامى فى البنية المعرفية والإجتماعية(1^). ويقر بيجوفيتش بكل موضسوعية بعدم تحريم الثرع لعمل المرأة خارج بيتها

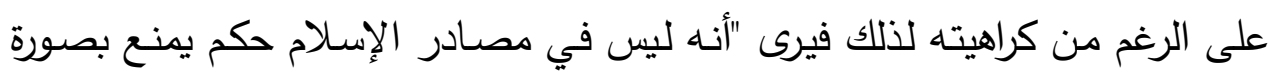

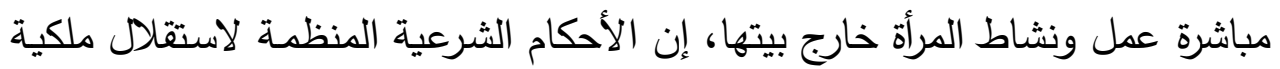

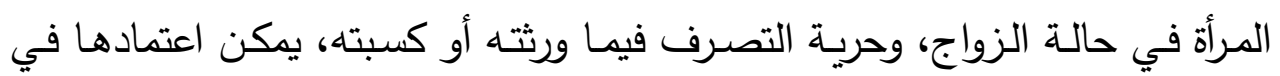
تحديد حق المرأة في العمل"(79) إلا أنه يقنن هذا الخروج بحالات معينة وليس بشكل مطلق، ومن هذه الحالات:

- - المتزوجة التي لم تُرزق بأطفال. - - المرأة التي ربت أولادها وأصبحوا مستقلين. - المرأة التي خرج زوجها للحرب فهي تعمل لسد حاجات الأسرة بدل الزوج

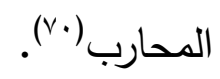
والملاحظ هنا على بيجوفيتش أنه يقول بعمل المرأة في حالة عدم وجود أولاد لها يحتاجون لرعايتها، بخلاف حالة من يخرج زوجها للحرب حيث إن خروجها هنا

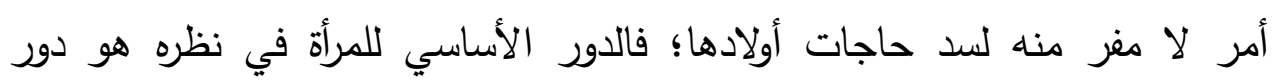
الأمومة؛ فتلك الوظيفة الأساسية والسامية قد فرضتها قوانين الفطرة قبل قوانين

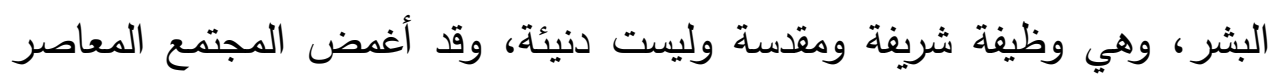

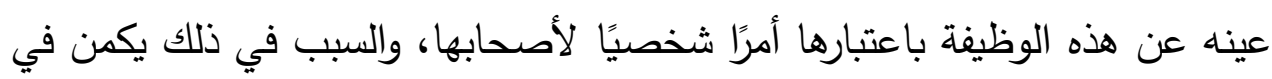
طبيعة الاقتصاد المعاصر؛ فالتطور الصناعي في حاجة متزايدة لأيدٍ عاملة كثيرة ورخيصة، ولم يجد المجتمع الصناعي أرخص أيدٍ عاملة إلا من جيوش النساء،

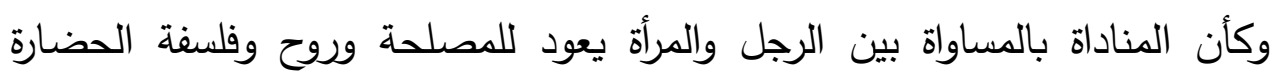

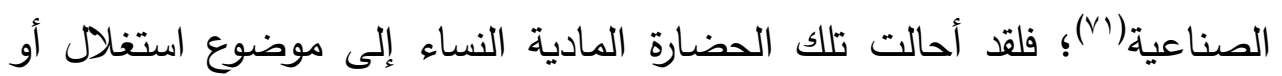


إعجاب، ولكنها حرمت المرأة من شخصيتها وأمومتها التي هي موضع الاحترام والتقدير ، وبذلك ألحقت الحضارة الغربية الخزي بالأمهات بصفة خاصة؛ ففضلت على الأمومة الاحتراف المهني في البيع والشراء والموديلات.... إلخ(rان. وانتقدت اقتصار دور النساء بالعالم الإسلامى على دور الأمومة بدلا من المشاركة فى الحياة الإجتماعية والسياسية(Vr)

وخير مثل لهذا الفكر المادي- برأيه- الكاتبة الفرنسية المشهورة سيمون دي بوقوار المعروفة بنشاطها في مجال تحرير المرأة؛ حيث تؤكد على أن المرأة ستظل

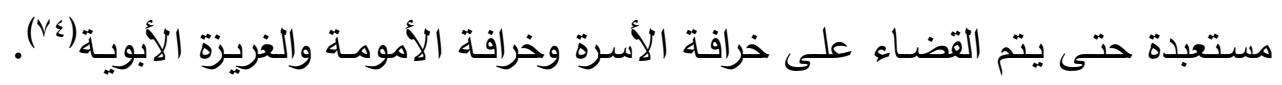
وبجانب الفكر المادي نجد كذلك الفكر الطوباوي يحط من قيمة المرأة فنجده يتحدث عن مؤسسات لتعليم وتربية الأطفال، ويكرس لغياب الأم ووضع الأطفال تحت رعاية الموظفين الغرباء، وكان أفلاطون أول من كرس لذلك بشكل نظري الاطعاب في جمهوريته

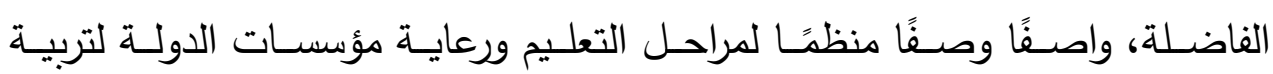
النشء (vo)، وهذا بالطبع يعود بالضرر الأكبر على الأطفال؛ حيث إن تربيتهم سوف توكل إلى أناس يقومون بالتربية لأجل الكسب المادي وليس بدافع الحب والعاطفة؛ فهي علاقات جافة وغير روحية تعود بالسلب على النشء، وهذا ما رفضه جان جالك روسو الذي رفض تلك النزعة العصرية التي توكل بكل راحة ضمير تربية الأولاد لأناس مستأجرين، مؤكدًا على أن كل شرور المجتمع الحديث تعود في المقام الأول

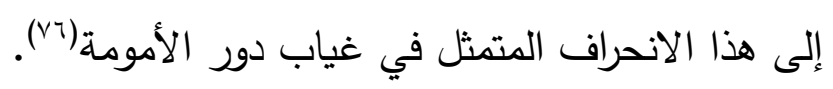

ويستتكر بيجوفيتش ذلك الضـغط المتواصـل مـن أجل تشـيل النسـاء خـارج المنزل من أجل مساهمتها في الإنتاج بالعمل الخارجي، ويرى أن ذلك الضغط يقوم

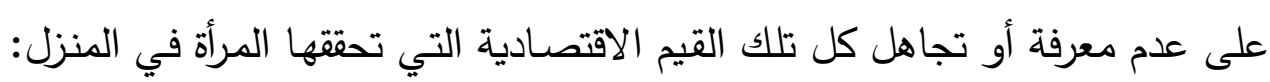
كالولادة وتربية الأبناء والمحافظة على الأمور الأسرية؛ فالمرأة تعمل داخل بيتها نحو تهو

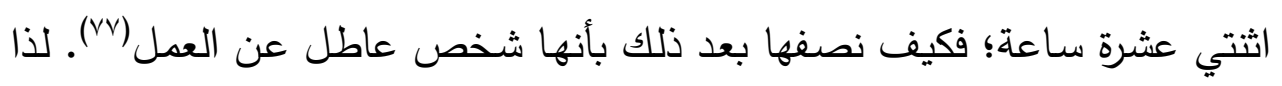
ينتهي بيجوفيتش إلى أن قيمة المرأة المُطلقة تكمُن في أمومتها، وكل من يهدم هذا 
الدور فهو لا يرفع من قدرها، ولا يزيد من احترامها وأهميتها؛ لأن حق الأمومة لا

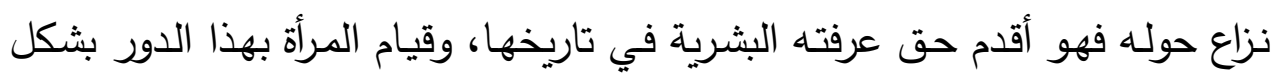

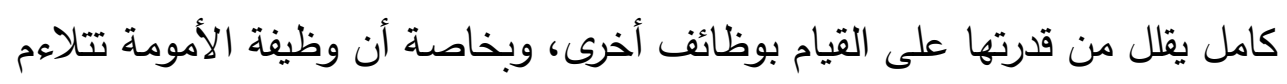

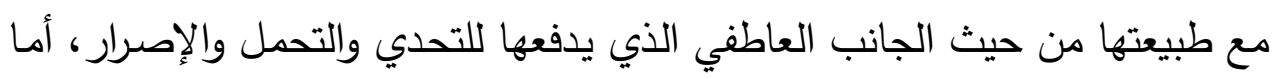

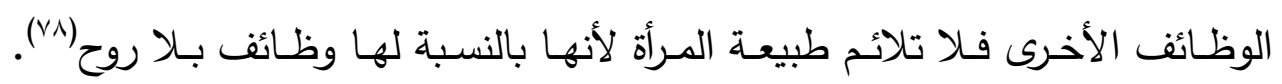

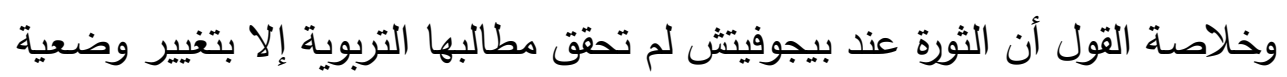

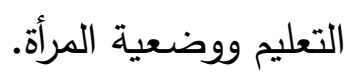

إن الثورة التربويـة بهذا الثكل كـزعم بيجـوفيتش- هـي التي تهيئ النـاس

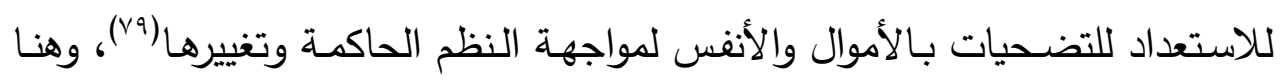

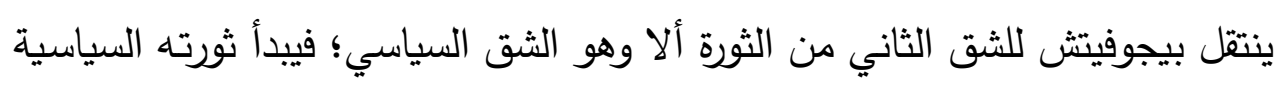

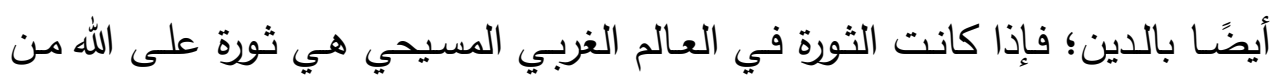

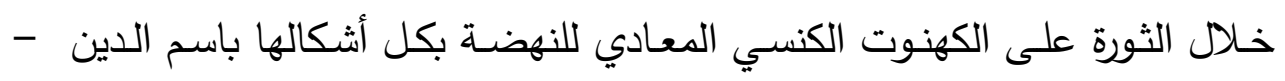

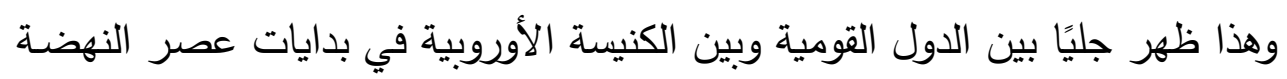

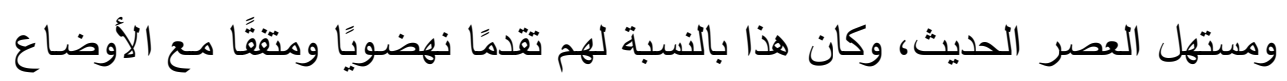

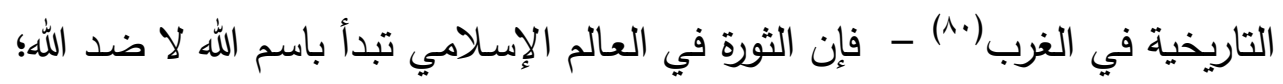

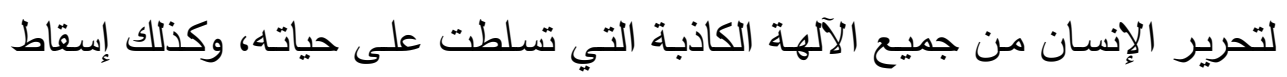

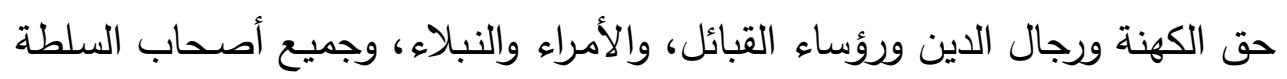

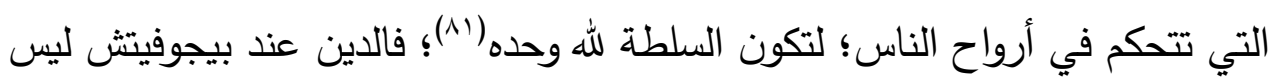

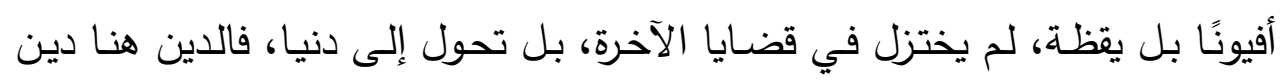

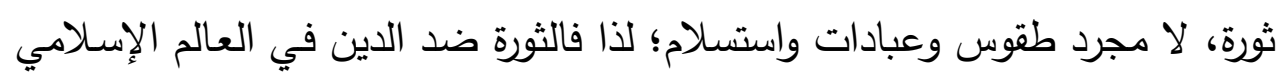

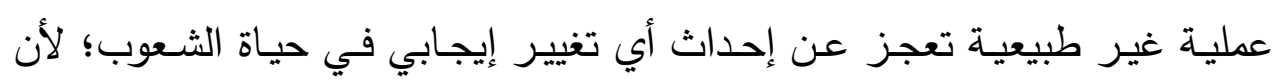

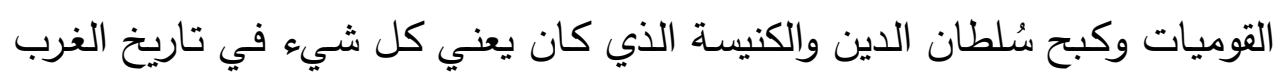

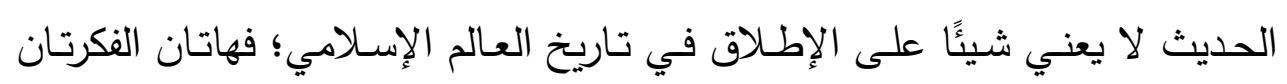

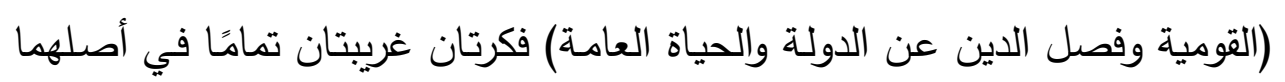


وتكوينهما على الإسلام، وكانت انعكاساتهما في العالم المسلم عُقًَا روحيًا عامًا، بل

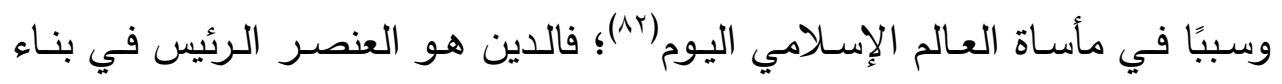
الدولة الجديدة التي كان يسعى إليها بجانب مبادئ الديمقراطية الحديثة، فيكون الدين

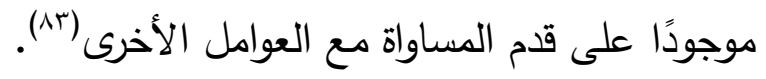

ويذهب بيجوفيتش إلى أن مطالب الثورات من تحقيق العدالة والمساواة والحريـة

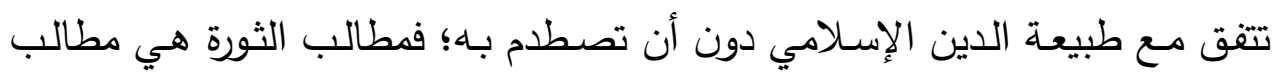
الدين وتحقيق مبادئه آنفة الذكر ، (لألك كانت الثورة باسم الله)؛ فوظيفة الثورة تحقيق تلك المبادئ واقعيًا عند عجز الدين عن ذلك، حيث إن عجز الدين عن التنفيذ

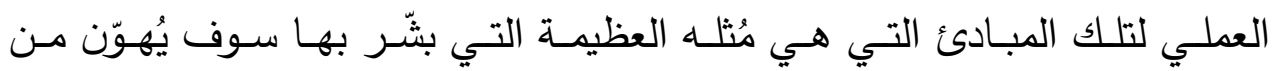
مصداقيته أمام المستضعفين والمقهورين؛ لذا كان لابد من تحقيقها من خلال الثورة أو ما يسمى بالسياسة والعنف الذى أمكن تبريرهما بحجة إيجادهما للوسائل المطلوبـة لتحقيق الأفكار العظيمة التي دعا إليها الدين، وعجز عن ترجمتها في الواقع؛ فلا

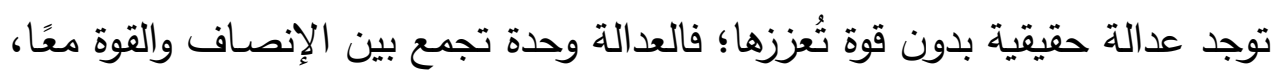

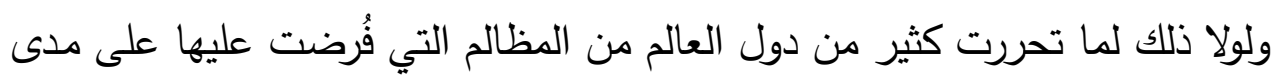
قرون عديدة(^^)، وهذا يعني أن الدين كظاهرة تاريخية له جانبان: جانب نظري يتمثل من فئل في تعاليم الوحي الإلهي النظريـة، وجانب عملي يتمثل في تجربـة الإنسـان العملية لتحويل تلك التعاليم لواقع عملي؛ فاله يُعلن الدين والإنسان يقوم بتطبيقه (ه) من أجل

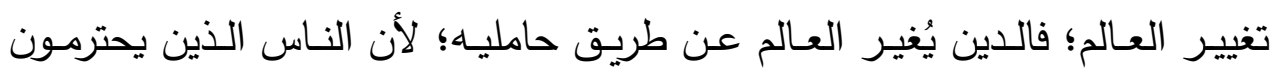
التعاليم الدينية الإلهية ويعرفونها جيذًا ويسعون لتنفيذها يضيقون ذرعًا بهذا العالم، ويبحثون عن عالم آخر يختلف عن ذلك العالم المُعاش فلم يجدوا أمامهح سوى الثورة باسم الدين (ז^)؛ ولذلك لا مفر من الإصـلاح إلا باسم الدين أولاً، وإلا كان العقاب

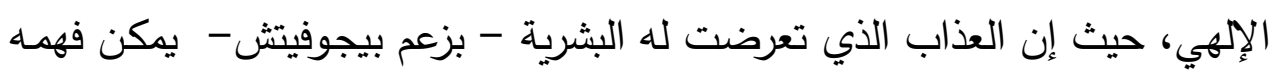
باعتباره عقابًا إلهيًا على محاولة الإنسان تغيير العالم، وإقامة جنة أرضية بدون الله بـانه

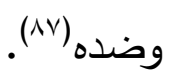


والثورة بهذا المعنى الديني لا تكون لمصلحة طبقة ولا لون أو جنس وقومية ولا

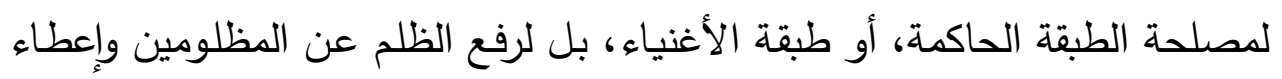
كل ذي حق حقـه(^)، وهذا بـالطبع لا ترضـى عنـه السـلطة الحاكمـة ممّا يدفعها

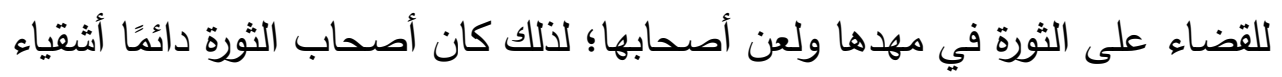
وملعونين؛ فهم في ثورة دائمة للوصول لهدف ما، يتطلعون إلى الجديد دائمًا، وقليل ما يتحدثون عن الخبز ولكن يتحدثون عن الحرية، يتحدثون عن الشخصية الإنسانية

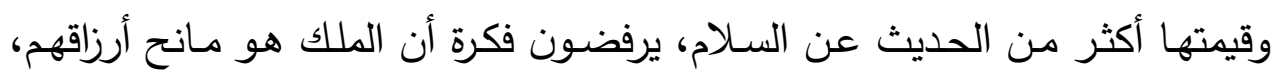

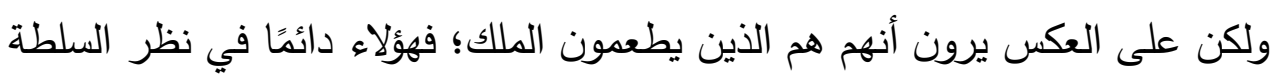

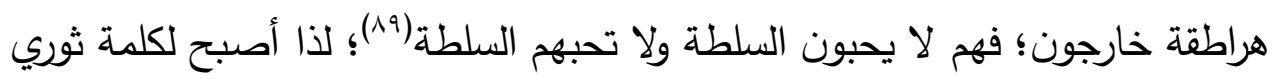
معنى بغيض عند الرافضين لها، ويبدو الثوري عندهم قذرًا هائجًا كثير الصـخب

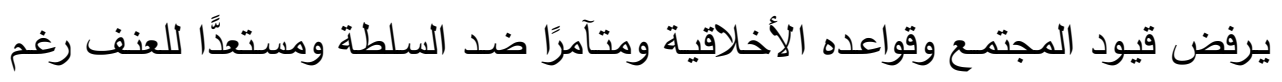
خشيته له ويعاني من عقد النقص ويحسد من هو أفضل منه ومشاكسًا في المبدأ والنزعة ولا يرغب إلا في الانغماس في الثهوات(·9). فأعداء الثورة يدركون تمامًا أنها تحرك لا عودة فيه قبل أن يصل إلى هدفه المنشود، وهو تغيير واقع مغاير تماءًا للواقع الراهن؛ لذا صارت الثورة عندهم لعنة وأصحابها ملعونين (19). والملاحظ هنا رفض بيجوفيتش لأي نوع من أنواع العنف والإرهاب واستخدام

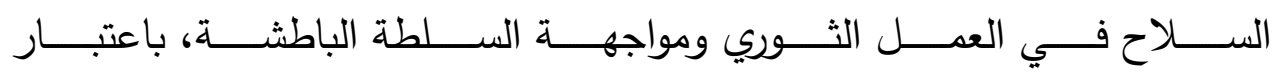
أن هذه أعمال غير أخلاقية وغير مثمرة، تضر المجتمع ولا تفيده؛ فيقول في نص

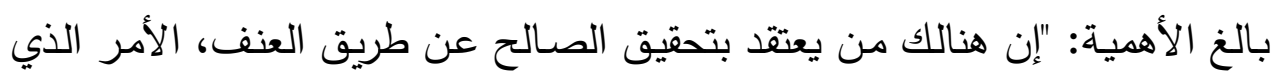

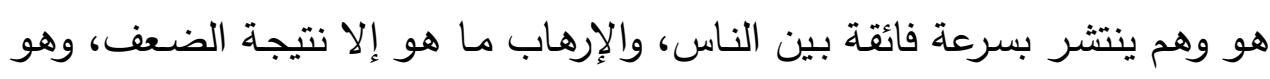
عمل غير أخلاقي وبلا ثمار فهو غير أخلاقي لأن هنالك ضحايا أبريـاء كُثرًا لمثل

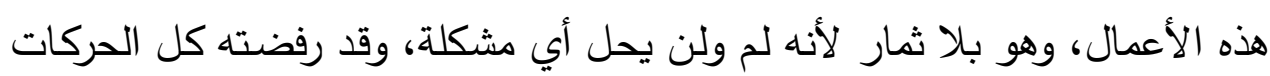

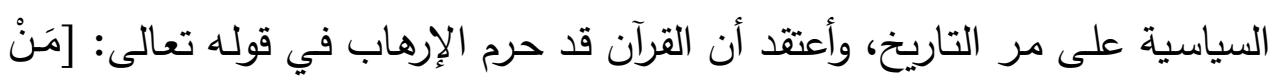

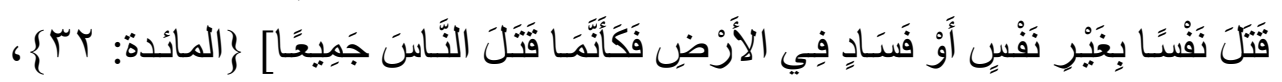


ولسوء الحظ فإن هنالك الكثيرين من يتغافلون عن هذا"(بهو، هذا من جانب ومن

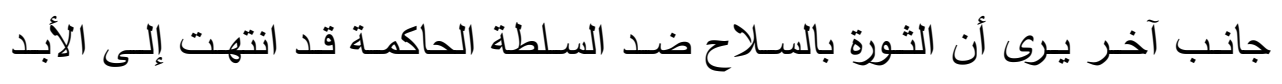
خصوصًا في الجزه المتطور من العالم، وذلك بسبب تعقد السـلاح الذي تستخدمه

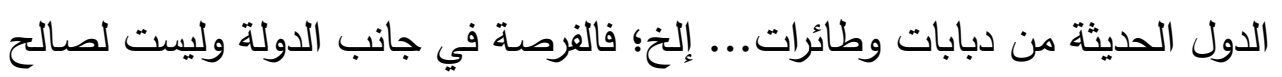
الثوار، وعلى الثوار أن يحسبوا حساب ذلك، ويستخدموا آليات أخرى غير السـلاح

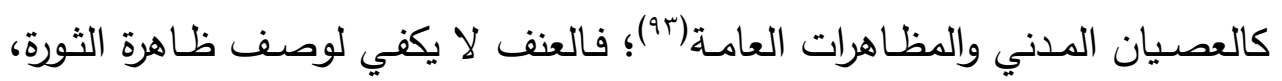
وإنما التغيير هو الوصف الأقدر بها، فلا يمكننا الحديث عن الثورة إلا حين يحدث التغيير ويكون بمعنى بداية جديدة(؟9).

وهكذا يتضح لنا أن الثورة عند بيجوفيتش لم تقتصر على ميادين الحضارة أو الاقتصاد أو المجتمع فقط؛ فهى ليست تغيرات متتالية في الحكم بموجب دورة متكررة

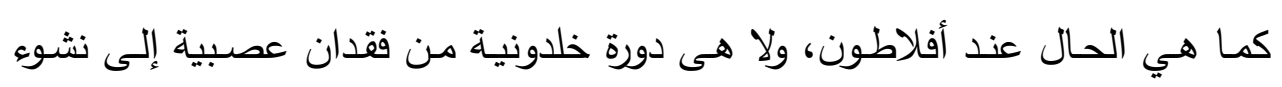
أخرى، ولا دورة مستمرة من البداوة للتحضر ، وهي كذلك ليست مجرد تغيير في الآلة

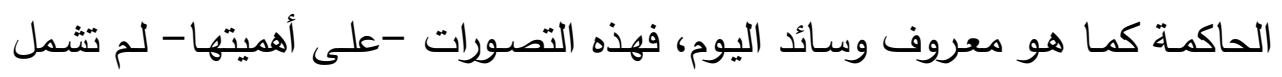
إمكان حدوث شيء جديد تمامًا(90)، ولكن لو نظرنا إليها من الداخل - كما يقول بيجوفيتش - لا باعتبارها عملية ولكن كجز من الحياة فستبدو لنا كالدراما التي تؤثر في حياة الناس كتأثير الأديان(T9). ثالثًا:- عوائق الثورة:

إن مفهوم الثورة بهذا الثكل الرافض لاختزال الدين في العبادات، وتأكيده على أنه أداة ثورية للتغيير وإعادة تنظيم العالم من جديد - سوف يصطدم دائمًا بتيارين بارزين في المجتمع - كما يقول بيجوفيتش- - هما: التيار المحافظ (أصحاب الفكر

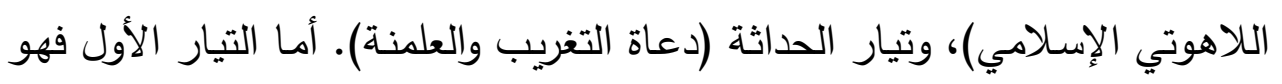
يمثل فكر رجال الدين الإسلامي المحافظين والمتعلقين بالأشكال القديمة دون تجديد؛ فالإسـلام عندهم دين مجرد خاص بإصـلاح النفوس دون أن يكون لـه شـأن بتنظيم العالم، وبقدر انغلاقهم على المعرفة المستنيرة ينفتحون على المعارف الغيبية؛ فدونوا 
كثيرًا من المعارف اللا معقولة ونسبوها للإسلام في حين أنها غريبة عنه؛ فهم بذلك لاهوتيون متحجرون في معتقداتهم، يقفون بالتفسير للعقيدة الإسلامية عند الماضي

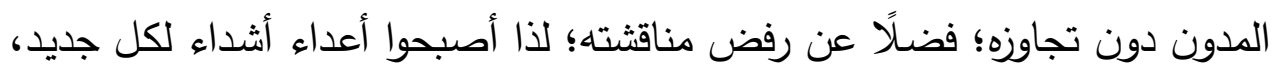
وكل محاولة لتطوير الشريعة كقانون من أجل تطبيق مبادئ القرآن على المواقف المستجدة حسب تطور الحياة يواجهونها بالهرطقة مبررين ذلك بحبهم للإسـلام، في

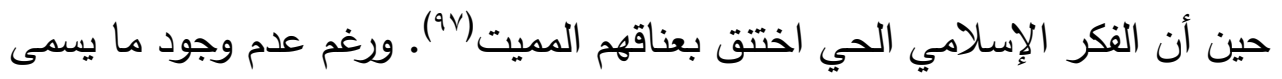

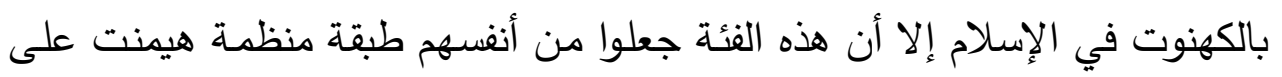

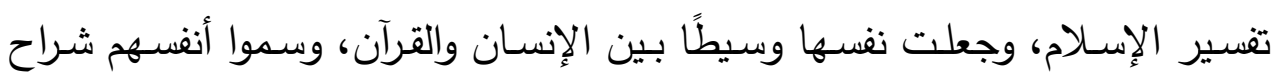
العقيدة وحراسها، واتخذوا من ذلك وظيفة مقبولة ومُربحة دون وخز من ضمير فيما

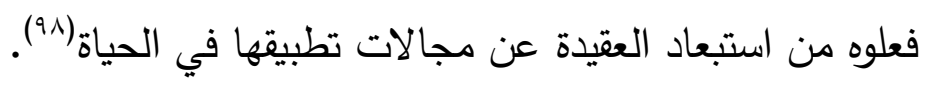

وعن علاقتهم بالسلطة يرى بيجوفيتش أنهح موظفو الأنظمة القائمـة وحُماتها وليسـوا حُمـاة الإسـلام والمسـمين، يفسـرون الإسـلام حسب رغبـة السلطة وحمايتها وخدمتها؛ فباسم الإسلام يبررون الحكم الوراثي، وباسم الإسـلام في بلد آخر يدافعون

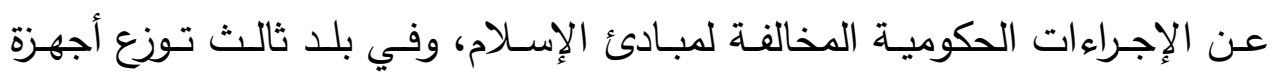
الحكومة الخطب المطبوعة على خطباء الجمعة لتأييد الحاكم والثناء عليه،، وقراءة الأدعية في المناسبات المختلفة لمديد عُمر الحاكم، دون أن يملك هؤلاء أي شجاعة لاءعة أنهاء لإنكار ذلك عليهم(99). فهم أتباع للسلطة يحبونها وينافقونها، يحبون الأمن والنظام والمؤسسـات والثناء من رؤسائهم، وأن يكونوا موضـع عطف منهم، وفوق ذلك هم

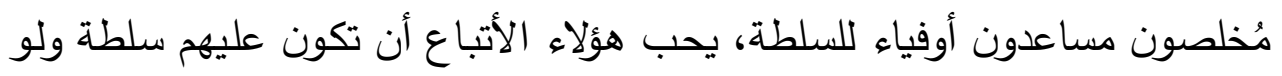
ظالمة، ويحب أصحاب السلطة أن يكون لهم أتباع ولو كانوا منافقين؛ فهم جميعًا متوافقون كأنهم أجزاء من كل واحد (.'). وبذلك أوكلت أمور الأمة المصيرية لأناس منافقين؛ فهم أناس غير صالحين في مكان غير مناسب؛ ومن ثم لابد من ضرورة

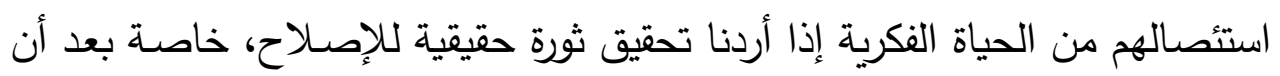
برهنت هذه الفئة على عجزها الكامل عن أي تجديد لمشروع النهضـة الإسلامي في لي لئ 
مجابهة الخطوب التي تلم بالعالم الإسلامي يومًا بعد يوم(1 +1). لذلك يؤكد بيجوفيتش

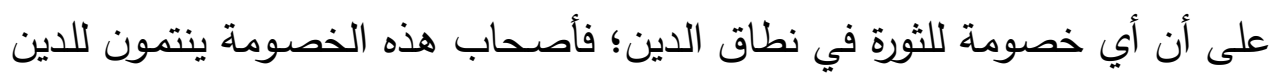
الرسـي، ديـن الدولـة فقط، الدين المؤسس الزائف وعلى العكس تمامًا فإن الثورة الزائفة التي تحولت إلى مؤسسة وإلى بيروقراطية تجد دائمًا حليفها في الدين الذي تحول هو أيضًا إلى مؤسسة وبيروقراطية(r +(').

أمــا التيـار الآخـر وهـو تيـار الحداثـة: فهـم التقــُميون أو العصـريون أو

المستغربون كما يسمون أنفسه؛ فهؤلاء يتطلعون إلى مناهج وأشكال أجنبية غريبة عن تراثنا وثقافتنا راجيين فيها طريق النهضـة للعالم الإسـلامي، متخذين من الفصل

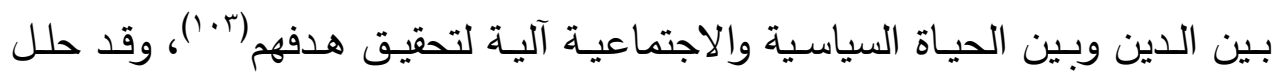
بيجوفيتش أفكار أصحاب هذا التيار تحليلً نفسيًا؛ فأرجع فكرهم هذا إلى تربيتهم في ولي

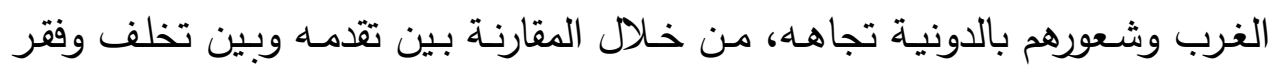
الثـعوب المسلمة، وبتلك التربية حُرموا من التربية الإسـلامية الصـيحة وفقدوا كل

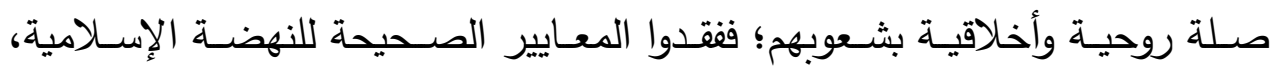
وتخيلوا أن النهضة لن تكون إلا بالتخلي عن أفكارنا وإحلال أفكار الغرب محلها في بي

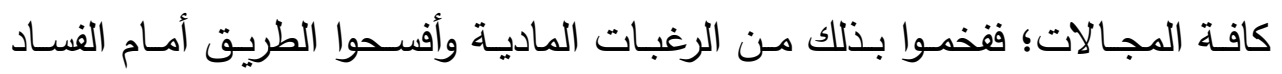

$$
\text { والفوضى الأخلاقية(؛ -1). }
$$

والمشكلة- عند بيجوفيتش - ليست في استخدام هؤلاء أساليب أجنبية، بل في

أنهم لـم يعرفوا كيفيـة استخدامها ووضـعها في موضـعها الصـحيح، ولم يُفلحوا في هي تطوير حس قوي يميز بين النافع والضـار، وما هو صحيح وما هو غير صحيح،

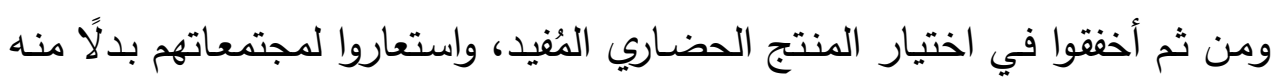

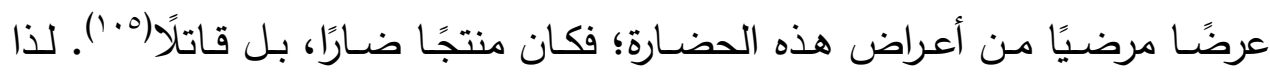
يصفهم بيجوفيتش قائًاً: "إن دعاة الحداثة في العالم المسلم حينذاك لم يكونوا من هن الحكمـاء الذين انبثقوا مـن صـميم شعوبهم، يعرفون كيف يُطبقون بطريقـة جديدة

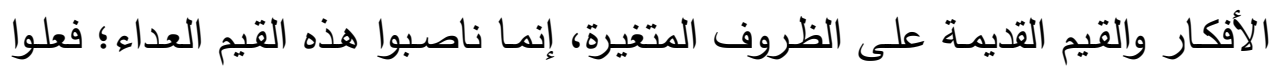


ذلك بسخرية باردة وبقصر نظر رهيب، وسحقوا بأقدامهم كل مـا هو مقدس عند الناس؛ فدمروا الحياة واستزرعوا بدلًا منها حياة مصطنعة غيرة ودير حقيقية"( +1.). وهذا لا يعني -بأي حال من الأحوال - رفض بيجوفيتش للانفتاح على مناهج الغرب، بل رفض الاستخدام الخاطئ لها، حيث يؤكد على أن أممية الإسلام تعني رفض التعصـب القومي والانغـلاق على الذات ورفض الآخـر ، بـل تبيح للإسـلام الانفتاح على القيم الحقيقية لكل الثعوب على أن تكون الإنسانية وقيمها هي حدود الإني

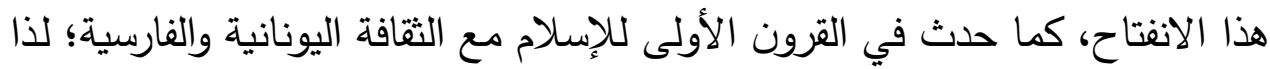

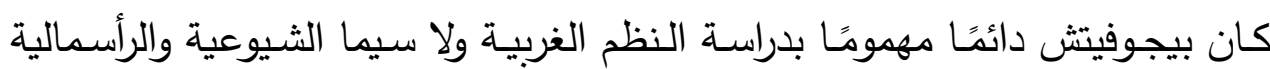

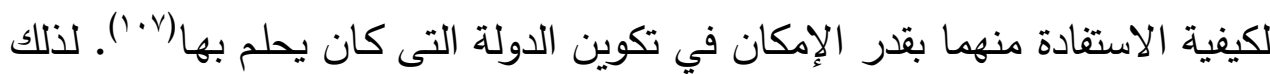

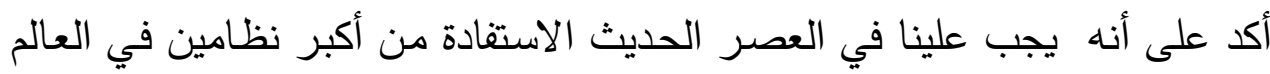
وهما: النظام الرأسمالي والنظام الاشتراكي؛ فنأخذ من الأول آليات التقدم الاقتصادي التي لفئ والحرية السياسية، ونأخذ من الثاني كيفية القضاء على صور الفقر ؛ "فإذا كان علينا

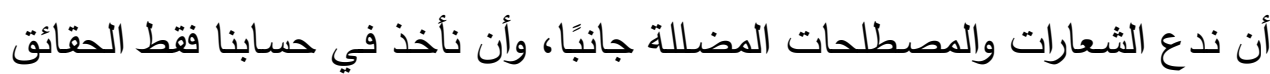
التي نراها ماثلة أمامنا؛ فيجب أن نعترف بالتطور الهائل في العالم الرأسمالي خلال

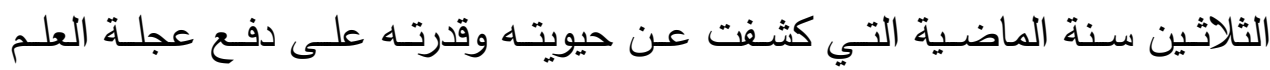

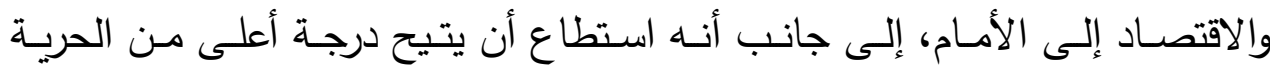

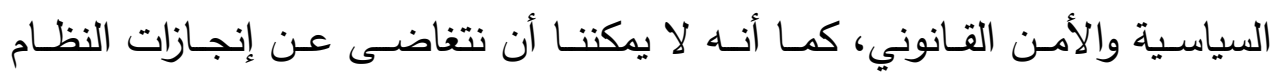
الاشتراكي وخصوصًا في مجال تعبئة الموارد المادية وفي التعليم وفي القضاء على لى صور الفقر التقليدية، ومن ناحية أخرى لا يسعنا أن نتغاضى عن جوانب مظلمة وغير

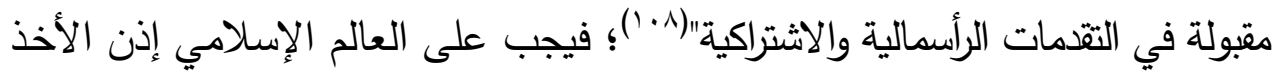

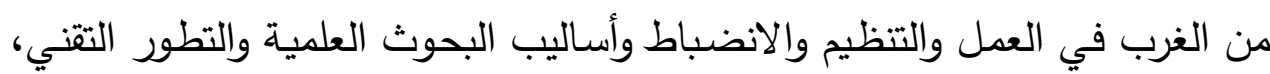

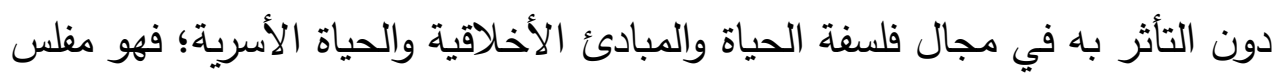

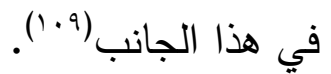

فالغرب كما يقول بيجوفيتش "ليس بفاسد ولا منحل، ولكنه قوي ومنظم ومثقف؛ فمدارسهم أفضل من مدارسنا، ومدنهم أنظف من مدننا، وذو معدلات حقوق إنسان 
أعلى من تلك التي عندنا، ونجده أيضًا ذا رعاية اجتماعية للفقراء أكثر تتظيمًا........

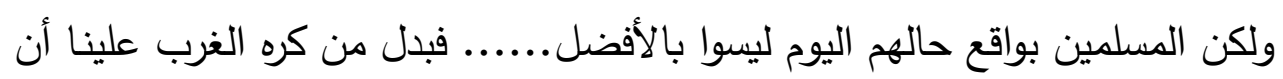

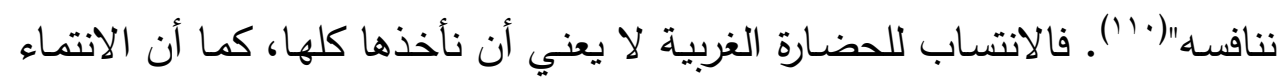

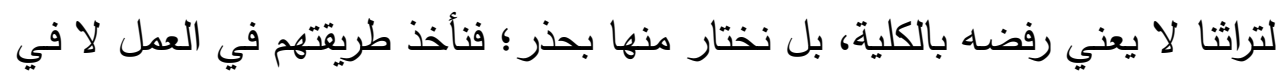

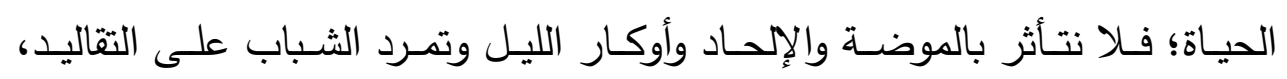

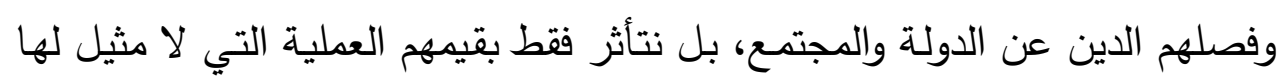
في المثابرة والعلم والشعور بالمسئولية؛ فليست المشكلة في الاستغراب بل في كيفية

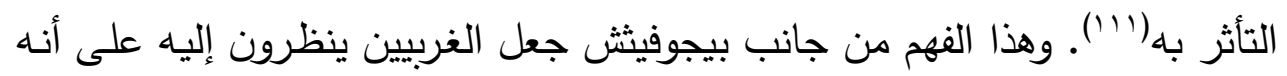

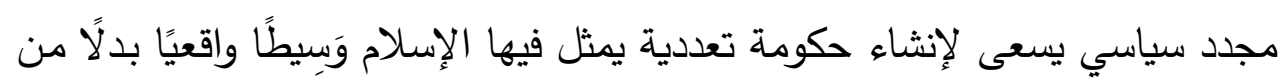

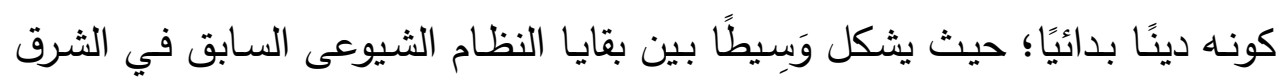

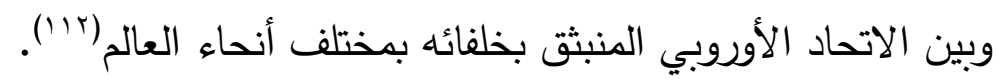

إن تيار الحداثة هذا - بزعم بيجوفيتش - أكبر خطر على الإسلام من التيار المحافظ، والسبب في ذلك يعود إلى كثرة أتباعه وهيمنتهم على الحكومات والتعليم والحياة العامة؛ فثكلوا جبهة ازداد نفوذها وتأثيرها ضد كل ما تمثله الفكرة الإسـلامية وهية

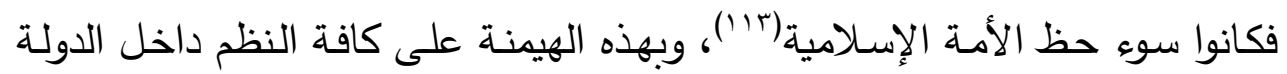

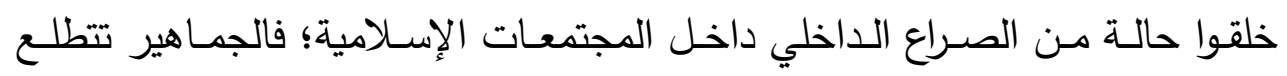
لمشروع إسلامي وينتظرون نخبة تقودهم لهذا ليعملوا معها، والنخبة الموجودة (أهل الحداثة) تفرض على الجماهير برامج أجنبية؛ فلا نجد من هؤلاء الجماهير استعدادًا

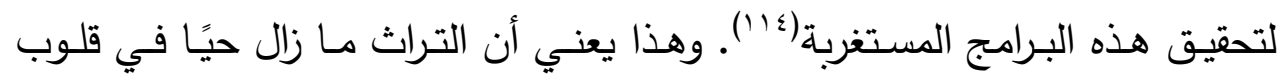

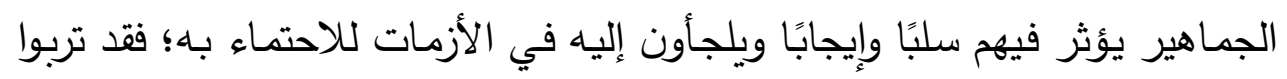

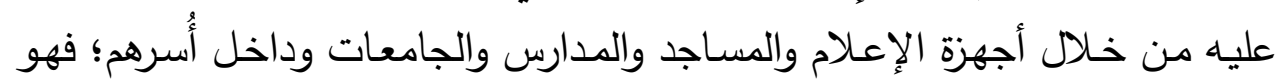

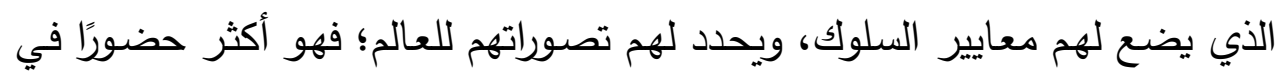
أذهـانهم مـن الحاضـر نفســ؛ لأنـه حضــور معنـوي وفعلـي، ذهنـي ومـادي، عقلـي وحسي (110). 
فالدعم الحقيقي - كما يقول بيجوفيتش - الذي يمنحه الثعب المسلم للسلطة السياسية يتناسب طرديًا مع مقدار ما يتمتع به هذا النظام من طابع إسلامي؛ فكلُما بعُدَ النظام عن الإسـلام قل الدعم الشعبي له؛ لذا تبقى هذه الأنظمة المعادية لنظم

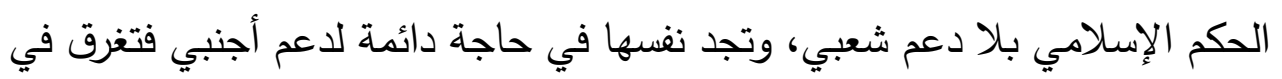

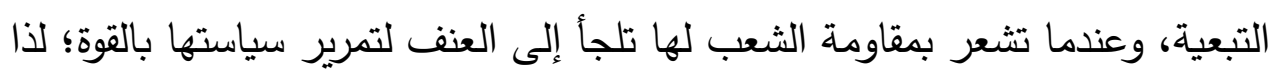

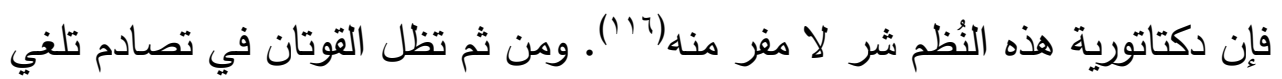

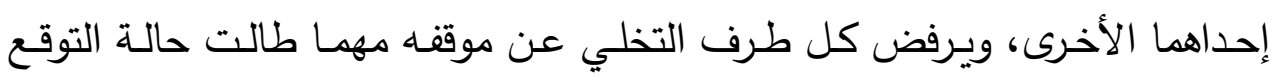

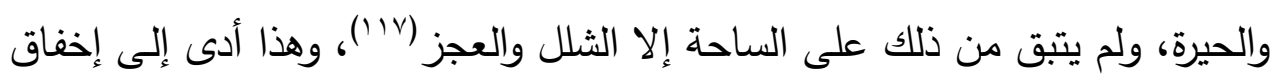

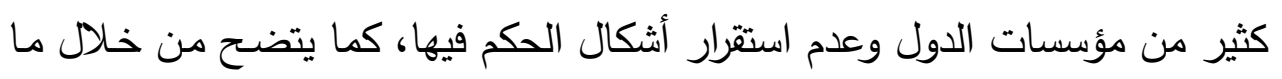
نشاهده من تحولات وانقلابات عسكرية متوالية، حيث إنه عند الصدام بين القوتين يتدخل الجيش لإنهاء الأزمة ويستولي على مقاليد الأمور ('l'). وهكذا تبـين لنـا كيـف أن هـذان التيـاران مـن أهـ معوقـات الثورة، حيـث تعلّق

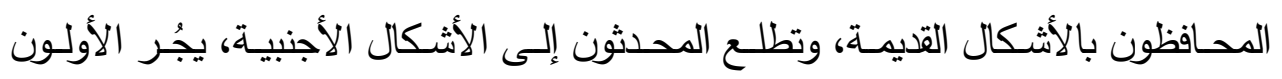

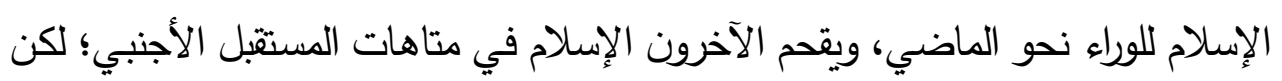

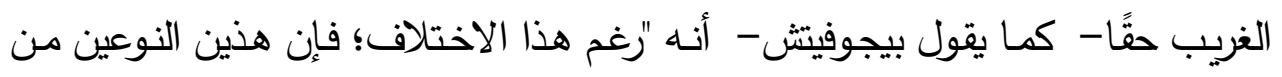
الناس بينهما شيء مشترك؛ فكلاهما ينظر إلى الإسلام من زاوية ضيقة، حيث لا يرى فيه

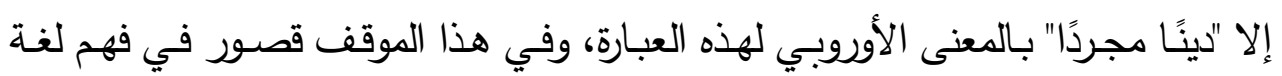
الإسـلام ومنطقه، بل إخفاق أكبر في فهح روح الإسـلام ودوره في التاريخ وفي العالم؛ لقد هدي أدى هذا القصور إلى سوء فهم جسيم للإسـلام باختزاله إلى مجرد دين مجرد، وتلك فكرة

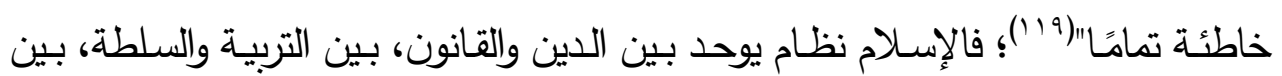
المثل الأعلى والمصلحة، بـين الجماعـة الروحيـة والدولـة، وهـو أخيرًا يوجـد بـين الإرادة

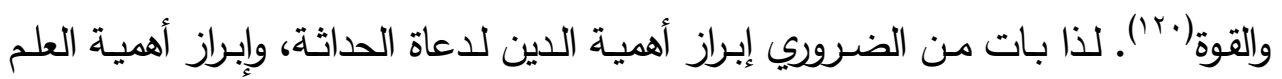

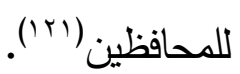


ومن هنا يرى بيجوفيتش أن الطريق الوحيد للخروج من الأزمـة تكوين نخبة جديدة تفكر وتثـعر بطريقـة إسـلامية، وترفع رايـة النظـام الإسـلامي مـع الجمـاهير المسلمة، وتتخذ الخطـوات العمليـة لتطبيقهه، ومـن ثم يتحقق الشـرط الأول والأهم لحدوث النهضـة، وهو التوافق والتعانق بين عناصر الفكر والقيادة من ناحية وبين

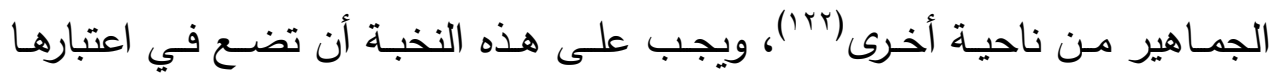
ماضيها الباهر، وأن يوحدوا بين تراثهم الخاص وبين متطلبات التقدم، دون رفض أب أي منهما؛ فلا تُستورد أفكار ثورية وبرامج إصلاح مقولبة وجاهزة لا تتناسب مع مشاكلنا وثقافتتـا، ويستشـهد بيجـوفيتش على ذلك بنمـوذجين متتاقضسين مـن حيث الرؤيـة لتراثهــا؛ فقد رفضـت اليابـان في مشـروعها الإصـلاحي دعوة مستغربيها في تبني الحروف اللاتينيـة واحتفظت بحروفها المعقدة وعلى الرغم من ذلك مُحيت الأميـة منها؛ في حين أن تركيا قامت بإلغاء الحروف العربية في الكتابة التي هي أرقى واتى وأكمل لغة في العالم وعلى الرغم من ذلك زادت الأمية فيها على خمسين بالمائة؛

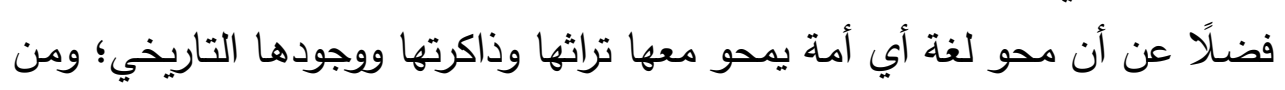
ثم لا تعرف هويتها ولا أين تمتد جذورها؛ لذلك وجدت تركيا نفسها بلا دعامة روحية

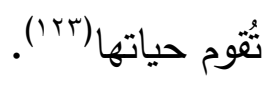

\section{لإيعًا:- من الثورة إلى القانون:}

تهمل الدولـة واجباتها تجـاه المواطنين إذا لم تحقق العدالـة الصـارمةهن أجلـ

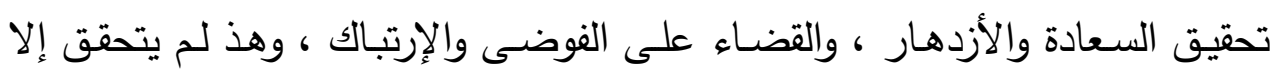

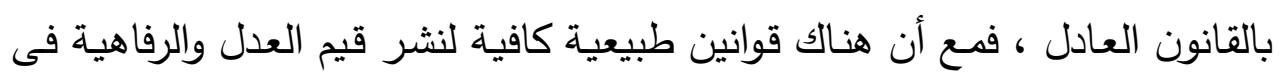

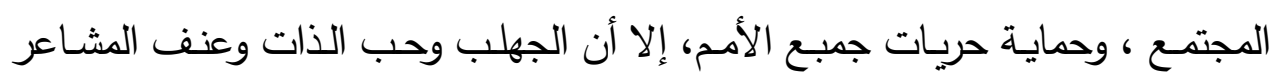

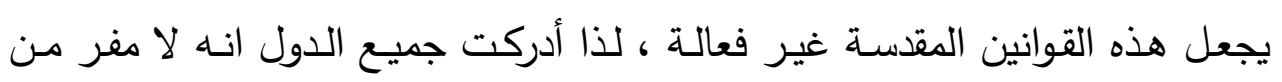

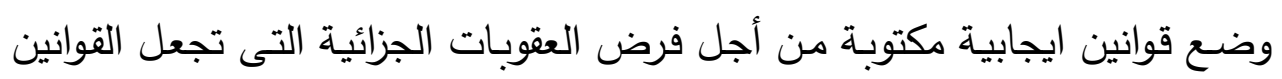

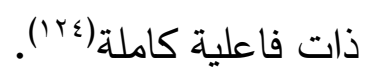


فالقانون كما يقول أوغسطين ضروري لكبح طبيعة الإنسان الخاطئة المتولدة عن الخطيئة، والمجتمع البشري -كما يرى هيوم- لن يكون لـه وجود بدون القانون

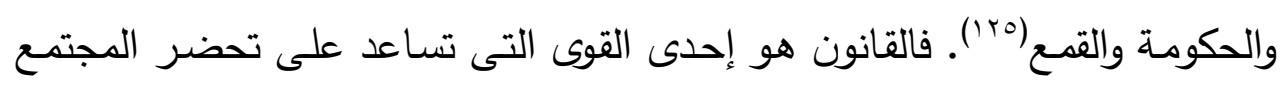

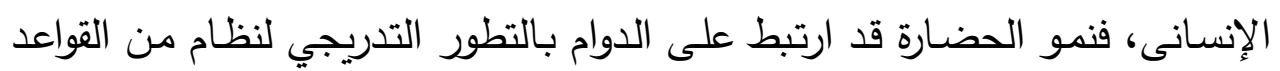

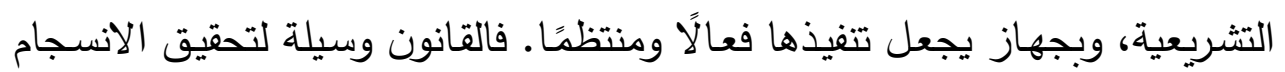

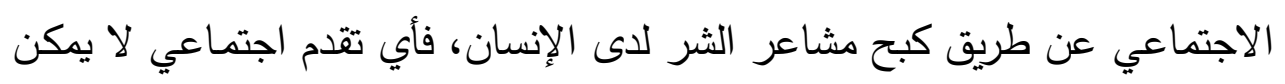

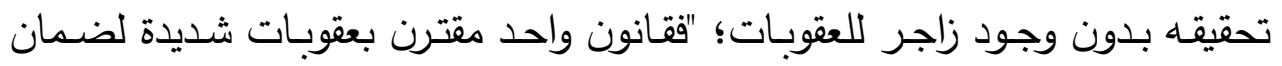

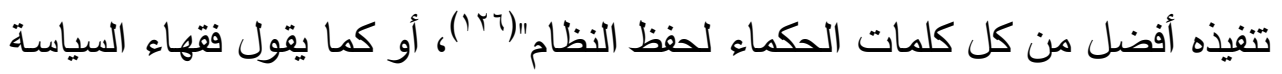

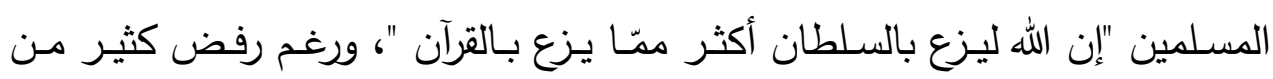

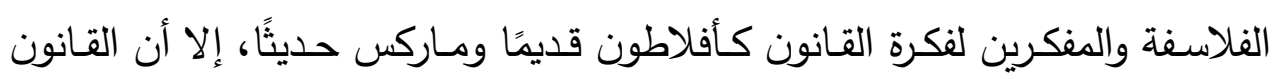

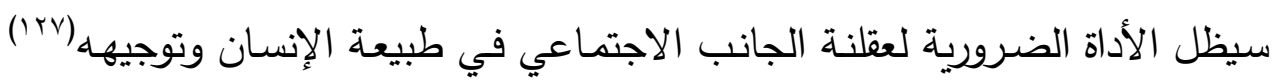

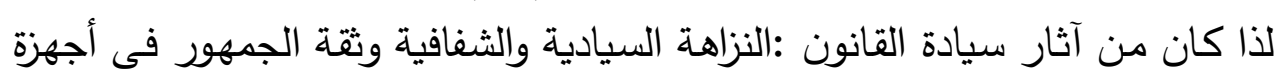

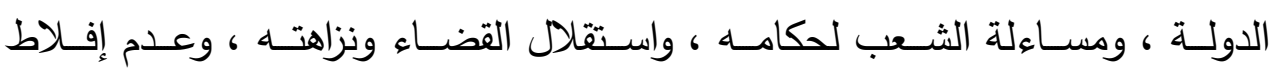

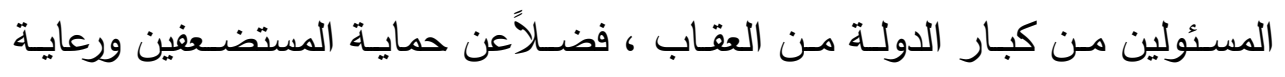

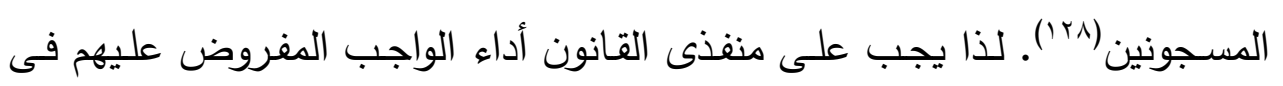

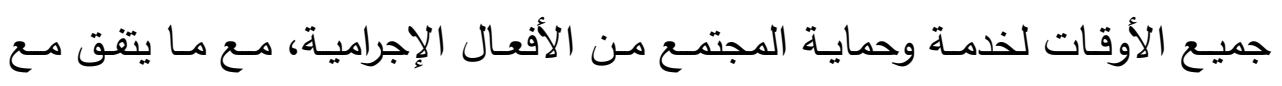

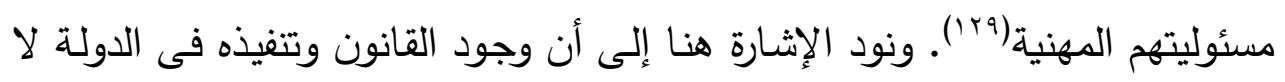

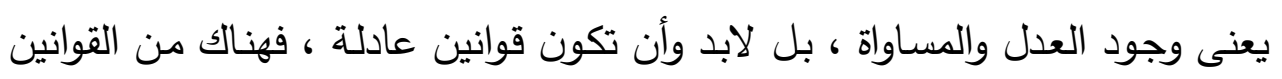

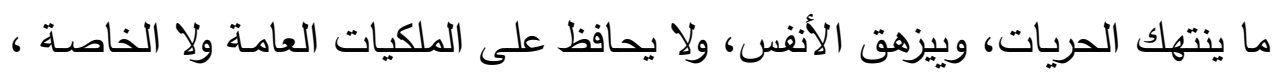

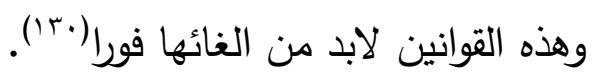

وقـد ذهـب بيجـوفيتش إلى أن الوضـع الطبيعـي الزمنـي لظهـور التشـريعات

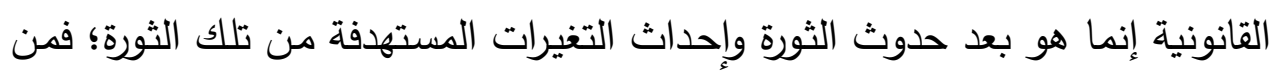

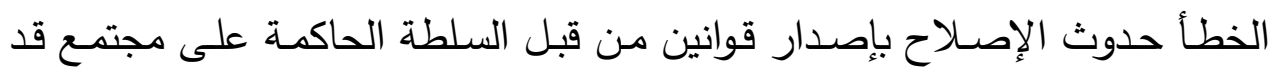
ينفرُ من هذه القوانين بسبب عدم استعداداته التربويـة والدينية لاستيعاب فكرة القانون

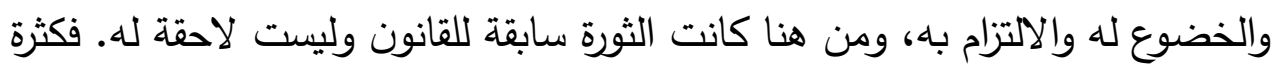


الفساد بكافة أشكاله في المجتمع لا يمكن القضاء عليها بمجرد سن القوانين من جهة

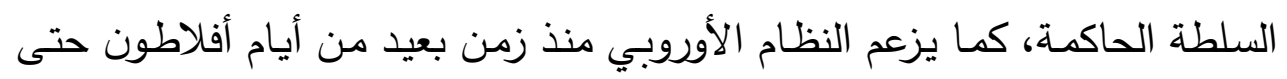

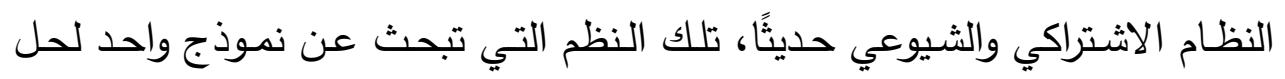
مشكلة المجتمعات وتتظيمها وتغيير العلاقات بين الناس، وتجد أن قوة القانون هو

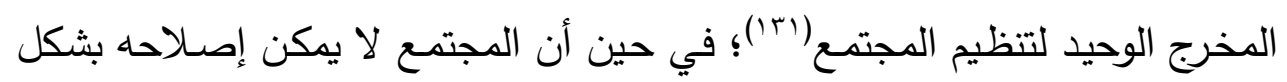

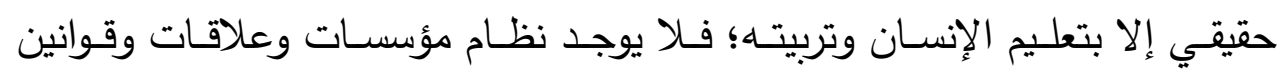

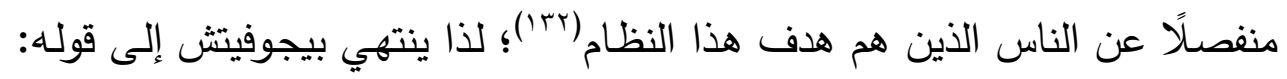

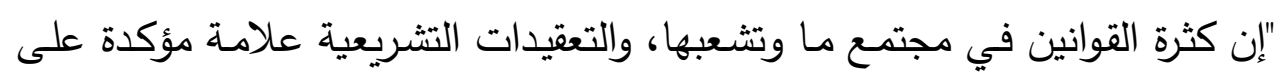

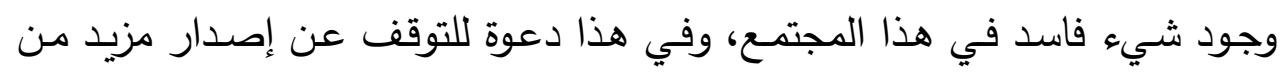
القوانين والبدء في تعليم الناس وتربيتهج؛ فعندما يتجاوز الفساد في بيئة ما حدًا معينًا

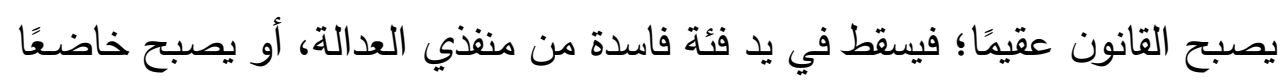

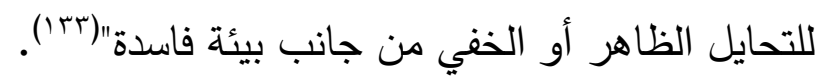

وتعود أهمية وضع القانون للحفاظ على مبادئ الثورة حين تتحقق وعدم ميل تجاوز السلطات الثورية للاستبداد باسم الثورة؛ فقد تستبد بعض الدول بالثعب مبادئ باسم

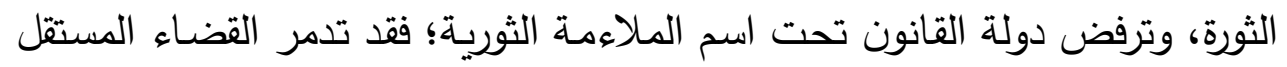

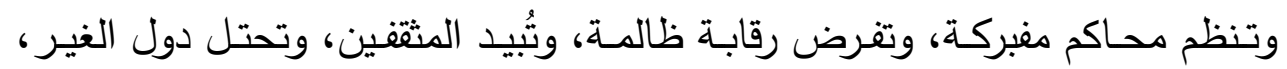

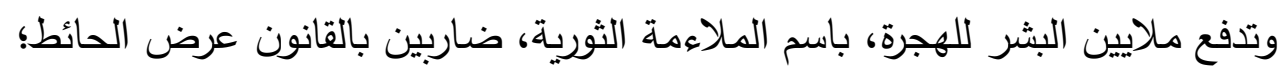

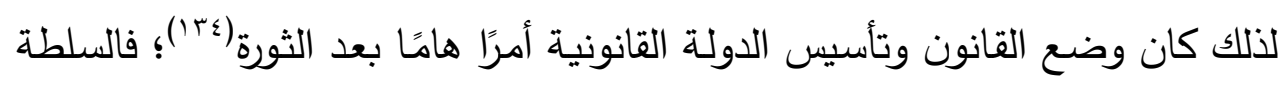
القانونيـة مقيـاس لتحضـر الثـعوب؛ فالثعب المتحضـر هو الذي يرفض الاستبداد ليضع السلطة تحت رقابة القانون، أمـا السلطة في الثعوب المتخلفة نجدها دائمًا

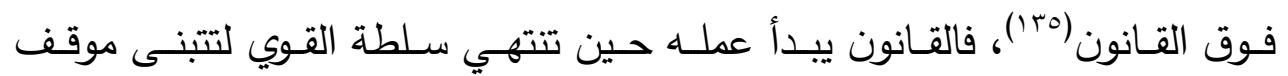
الضعيف بدلًا من مصلحة القوي، ولهذا السبب تتاضل الشعوب في سبيل الاستور ،

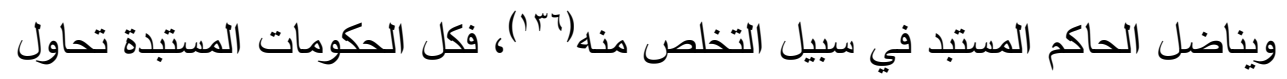

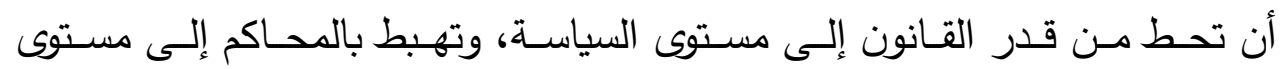
السكرتاريات، ولكن لأن ذلك الطراز من الحكومات لن ينجح في محاولته هذه نجاحًا 
كاملًا؛ فإنها عادة ما تتجاهل المحاكم بوصفها سلطة قضـائية فتتجاوزها باستخدام المحاكمـات المباشـرة بواسطة السلطة التنفيذيـة ومراكز الاعتقال، أي بوسيلة بعيدة

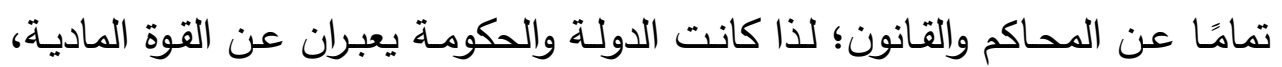
ويمثل القانون والمحاكم القوة الأخلاقية، والاعتراف بقوة القانون يوازن القوة المادية

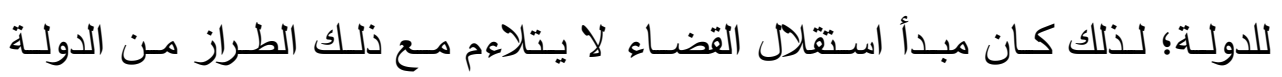

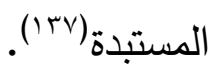

وعلى الرغم من محاولة السلطات المستبدة القضاء على القانون أو وضعه في

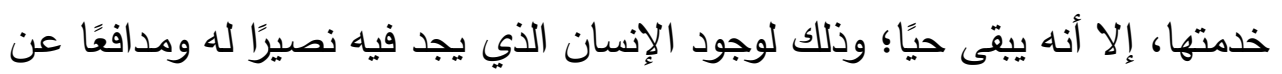

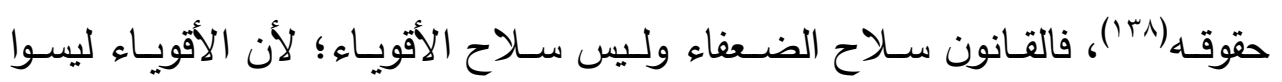
بحاجة إلى القانون؛ لأن القوة بطبيعتها تطدع أن تكون بلا حدود ولا قانون يحدها؛

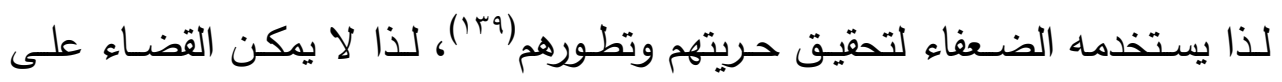

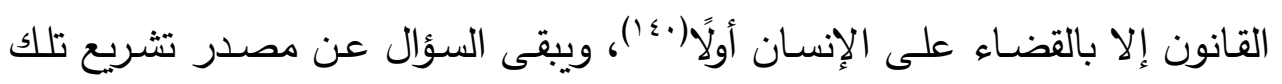

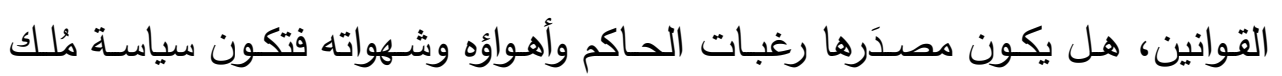

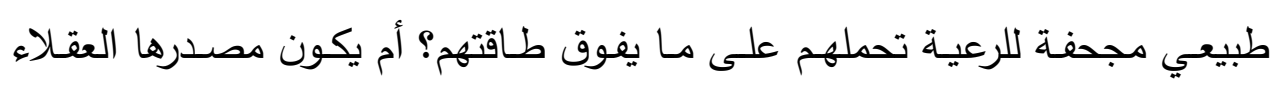
وأكابر الدولة وبصائرها؛ فتكون صناعة إنسانية وليست إلهية، نافعة في الدنيا فقط

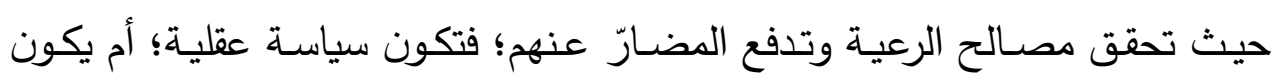
مصدرها الثـرع فتكون مفروضــة مـن الله يشـرعها لتحقيق منـافع النـاس في الدنيا

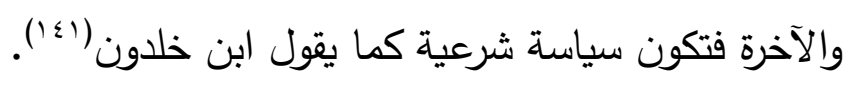

للإجابـة على السؤال يطرح بيجوفيتش أولًا معنى فكرة القانون والهدف منـهـ

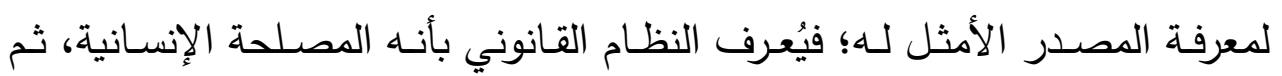

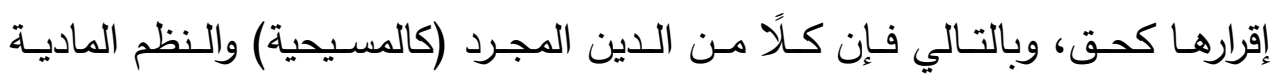
(كالاشتراكية والثيوعية) لا يصلحان للقانون؛ لأن الدين المجرد لا يفهم المصالح،

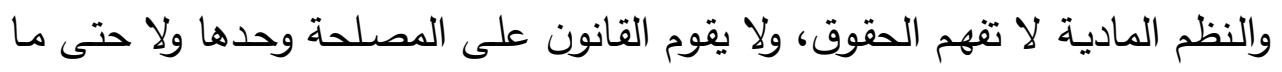

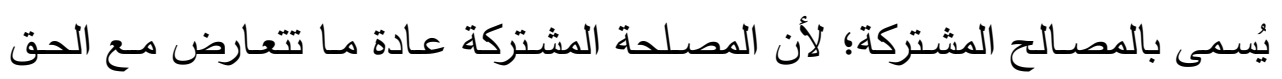




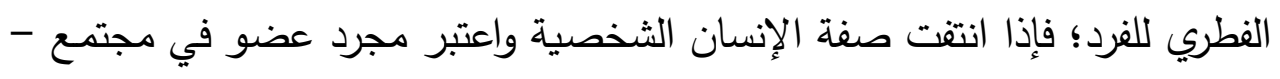
كما الحال في النظام الاشتراكي - فلا يكون لـه بالبداهـة حقوق مطلقة أو فطريـة، ولكن لله حقوق تمنحها الدولة فقط، وفيها عدا ذلك ليس لله حقوق أخرى؛ في حين أن حقوق الفرد الطبيعيـة كالحريـة والملكيـة الخاصـة وحريـة الفكر والعقيدة حقوق غير

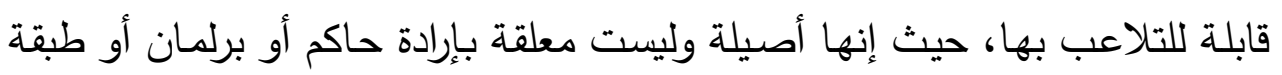

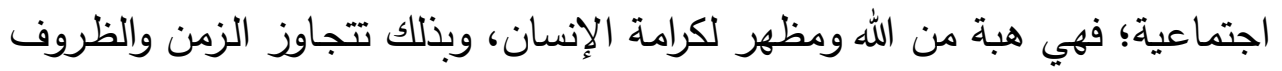
والتاريخ وتسـو إلى فعل الخلق، وهنـا تكمـن العلاقـة بين تلك الحقوق الطبيعيـة

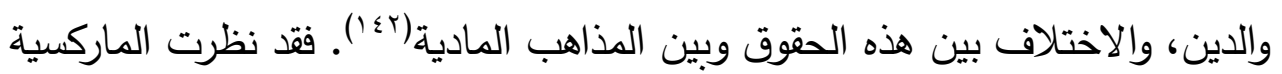

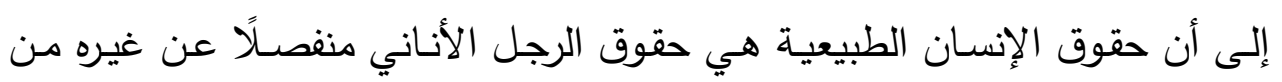

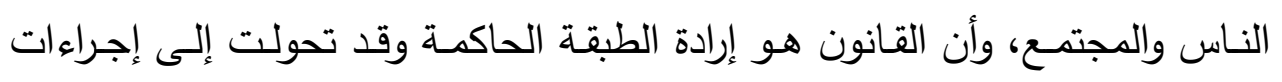

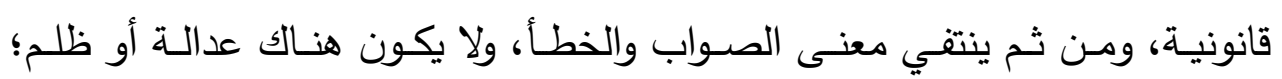

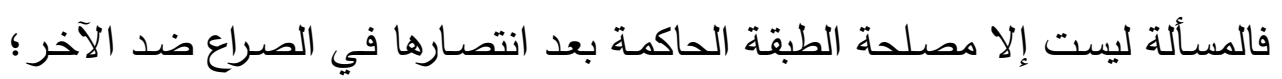
فالطبقة التي تخرج منتصـرة في الصـراع الطبقي تعلن مصـالحها أو إرادتها قانونًا، وبالتالي فالقوي وحده هو الذي يستأثر بجميع الحقوق، وهذا يتعارض تعارضًا تامًا مـع جوهر القانون الذي هو بطبيعته حق الأضـف؛ ليس هذا فحسب؛ بل إنـه إذا كان القانون هو إرادة الطبقة الحاكمة؛ فسوف تصبح كل السلطات المهيمنة في كافة

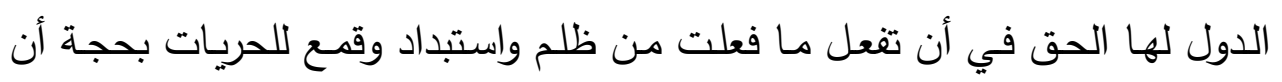

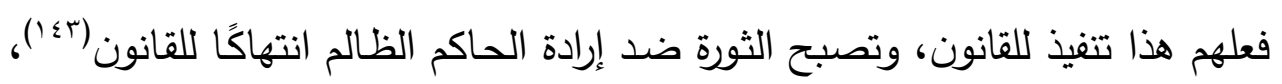

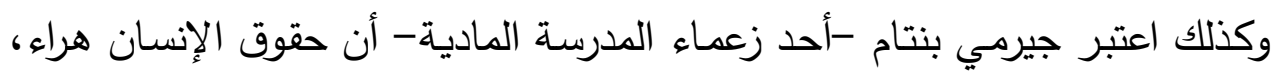

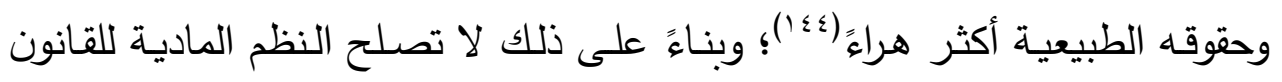

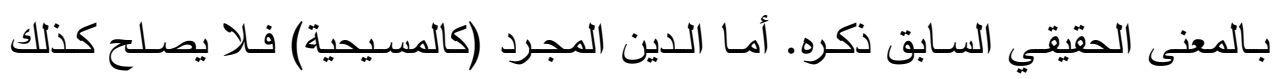

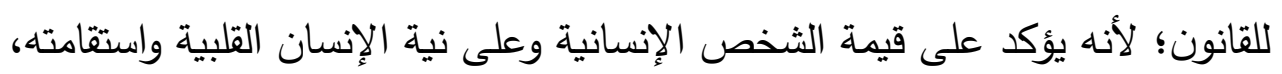

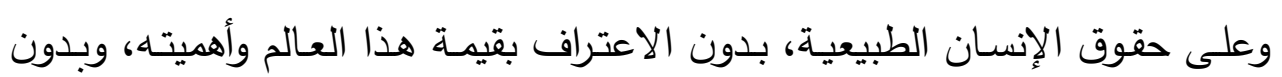

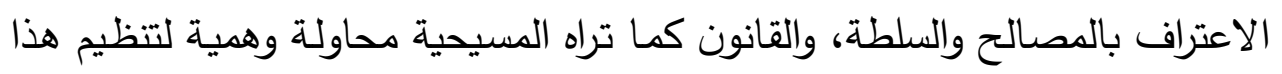


العالم، محاولة مصيرها الفثل في النهاية؛ فلم يأتِ المسيح إلا من أجل الدحبة التي

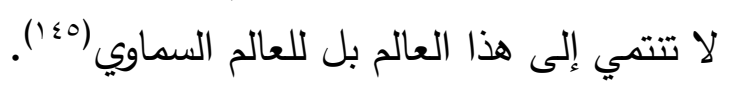

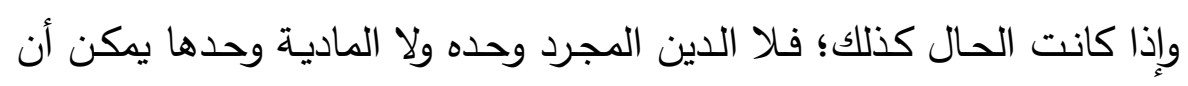

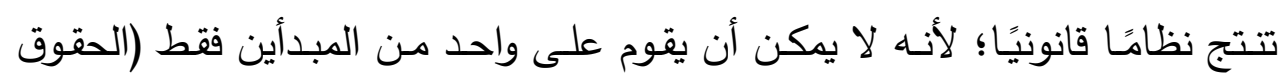

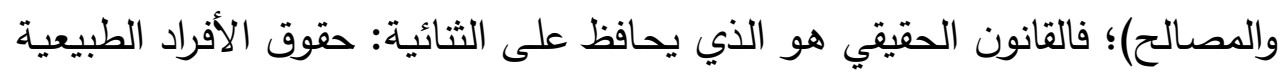

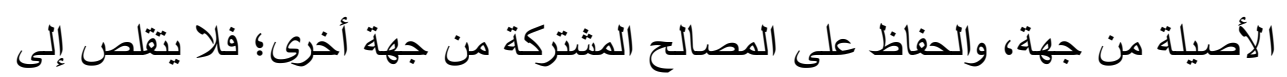

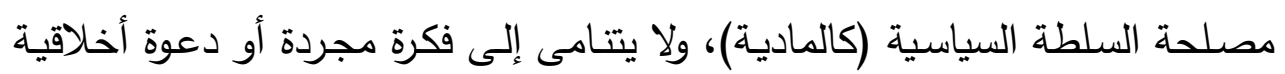

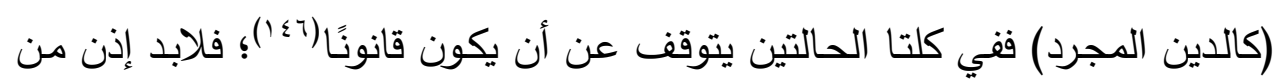
مصدر آخر يجمع بين تلك الثنائية لينتج قانونًا حقيقيًا.

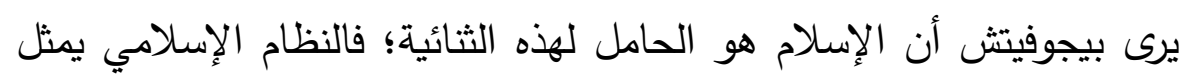

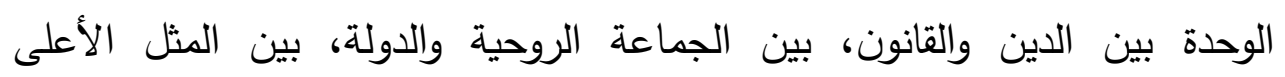

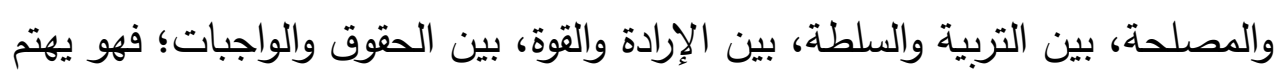

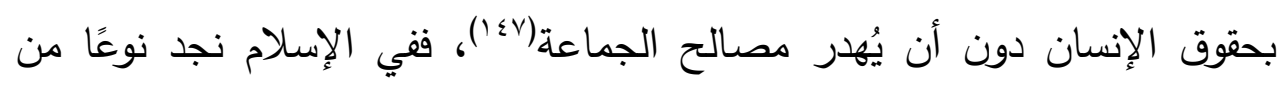

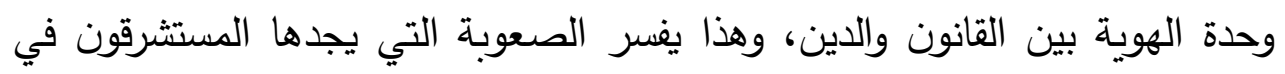

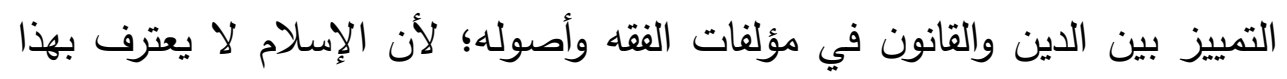

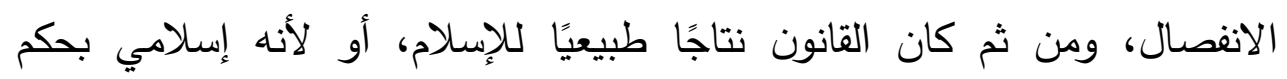

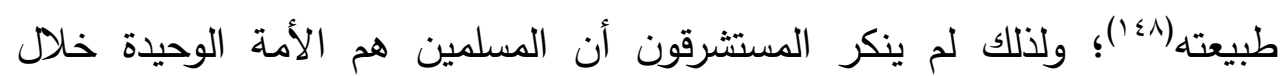

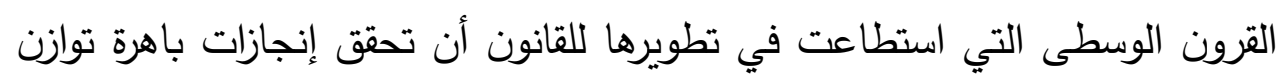

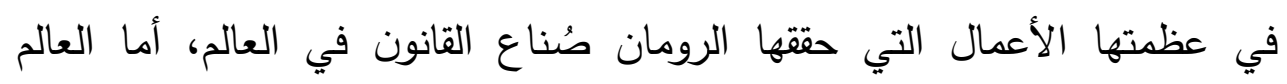

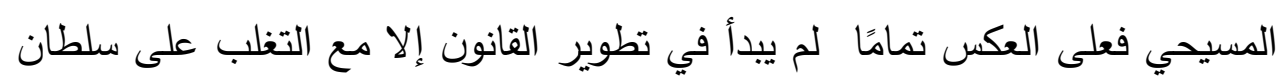

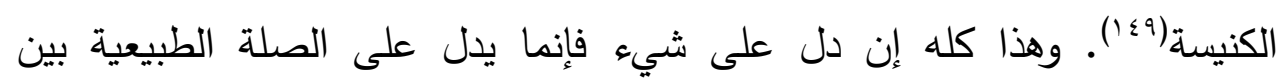

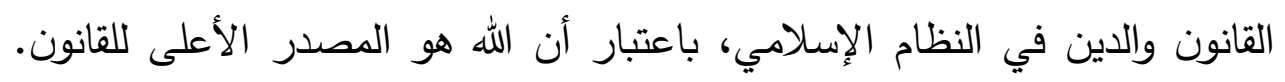

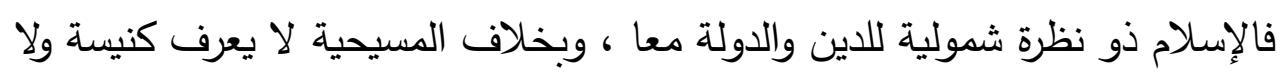
كهنوت(0.1). والسؤال الذي يطرح نفسه هنا: إذا كان الله هو الدصدر الأعلى للقانون 
في الإسلام من خلال الشريعة الموحاة؛ فهل النص الديني (القرآن تحديدا) شرع

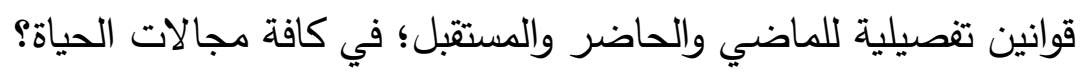
يعترف بيجوفيتش بأن القرآن الكريم يشتمل على عدد قليل مـن القوانين

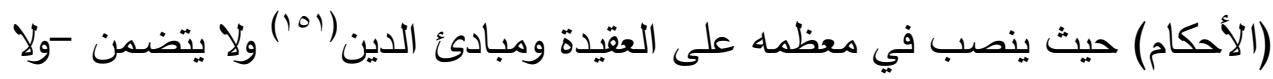

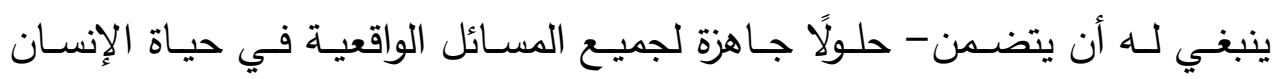

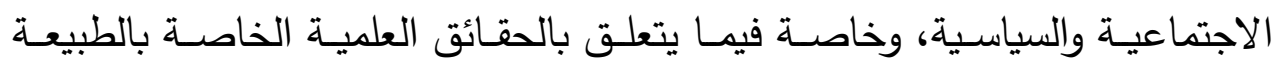

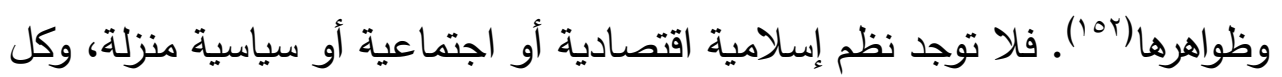

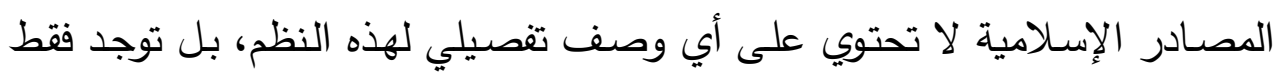

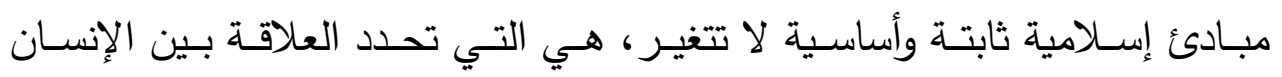

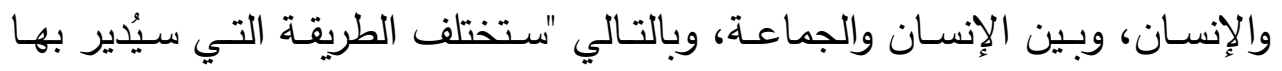

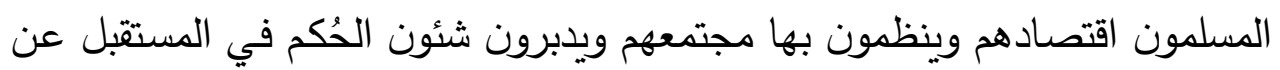

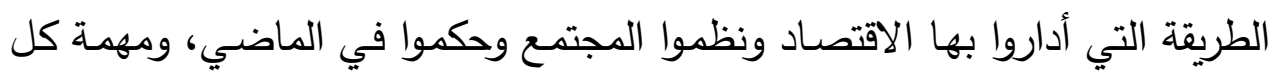

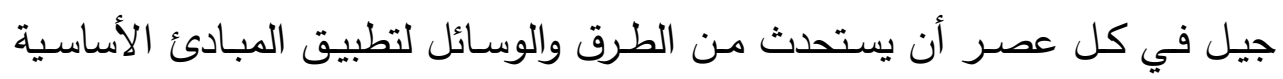

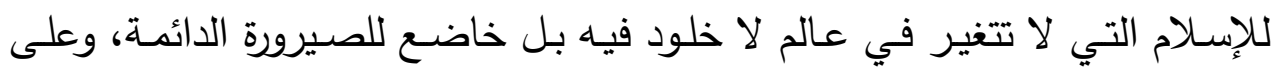

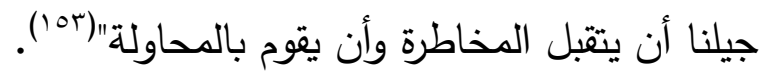
وهذه المبادئ( أ) )تمثل في: 1- إقرار المبدأ الجمهوري وإلغاء نظام الملك: فالإسلام لا يعترف بمبدأ الميراث

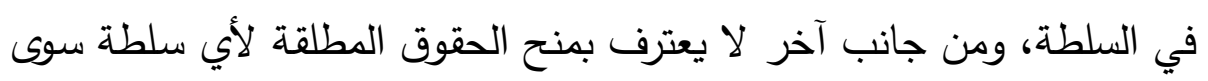

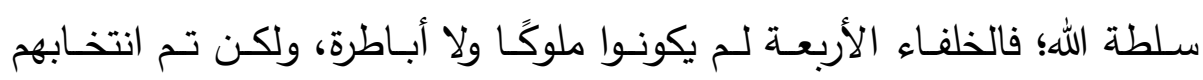

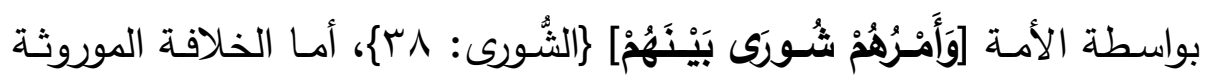

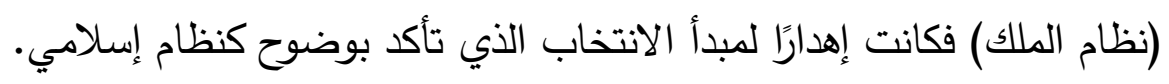
وهذا يُعنى أن الأمة هي مصدر السلطات؛ فهي التي تتصب الحاكم التي تريده،

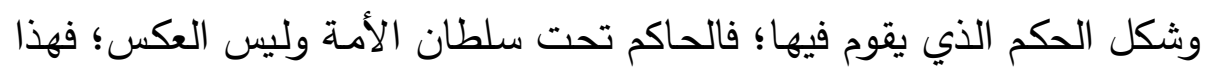


حق أعطاها الإسـلام لها، وليس منحة من الحاكم، وهذا هو الأسـاس الذي قام عليه الحكم الإسـلامي في عهد النبي والخلفاء الراشدين من بعده، بخلاف ما ها جاء بعد ذلك، حيث لم تكن الأمسة هي مصدر السلطات، ولكن كان الحاكم المستبد هو كل شيء في الدولتة وبيده جميع السلطات، ولم يكن للأمسة حق هق هـن حريتها السياسية(100). وكان نظام الوراثة في الحكم هو السمة السـائدة (نظام الملك)، ولا سيما في الدولـة الأمويـة والعباسية، ذلك النظام الذي ترتب عليه عليه عواقب وخيمة كانت من أهم أسباب انهيار الحضـارة الإسـامية ومنها: ظهور

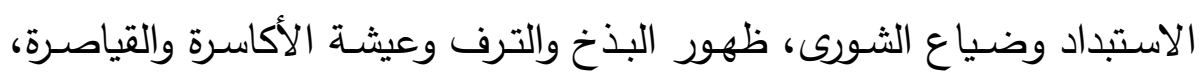
ظهور العصبيات القومية وتطرف الثعوبية، انقسام القيادة الإسلامية التي كانت واحدة إلى قيادتين: سياسية حصل عليها الملوك بالقوة والأخرى دينية قام بها الإنايها

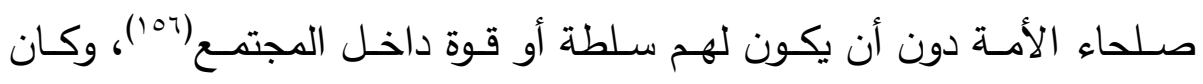
الصدام هو السمة السائدة والمسيطرة على العلاقة بين أهل القيادتين، وكان من دون

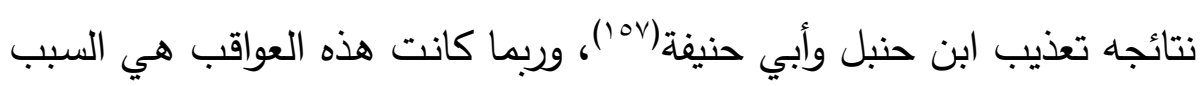

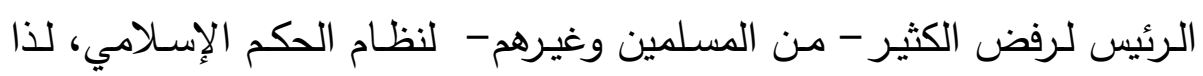
كانت طموحات بيجوفيتش منصبة كلها على تأسيس دولة إسلامية ذات مبادئ ديمقراطية، وكان هذا الأمر يروق كثيرًا لأصحاب التوجه العلماني والذي كان

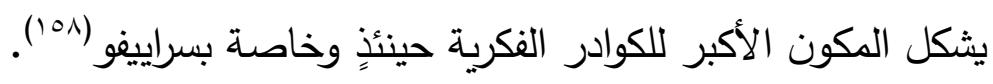
r- المســاواة بـين النـاس: فالإســلام لا يقبـل تصنيف النـاس طبقًا لمواصـفات خارجية؛ مثل التميز الطبقي والتمييز العنصـري والجنسي وغيره من أشكال التمييز بين الناس؛ فكل ذلك مرفوض من الناحية الأخلاقية والسياسية [إنَّ

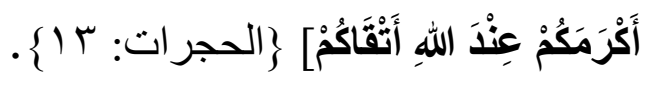

ץ- وحـــة المسـلمين وأخـوتهم: فالمسـلمون جماعـة واحـدة مـن الناحيـة الدينيـة

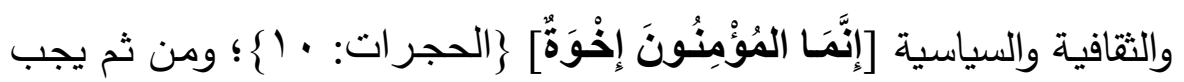
إلغاء كل ما ييُبث الفرقة والنزاع بين هذه الجماعة سواء ما كان منـه متصـلً 
بالأفكـار كـالفرق والمـذاهب والأحـزاب، أو كــان متصـلًَ بالأشـياء الماديـة كالتفاوت الصـارخ في الثروات والمراكز الاجتماعيـة، وتكون العلاقـة بينهما علاقـة أخويـة لا عبوديـة؛ ومـن ثم لا مكـان في النظــام الإسـلامي للنظـام الإقطاعي القائم على علاقة السيد بعبيده.

ع - إقرار الملكيات: فالإسـلام يقر الملكية الخاصـة حفاظًا على جهد الأفراد، وفي نفس الوقت يقر بملكية المجتمع لمصـادر الثروة العامـة وبخاصـة الطبيعيـة؛

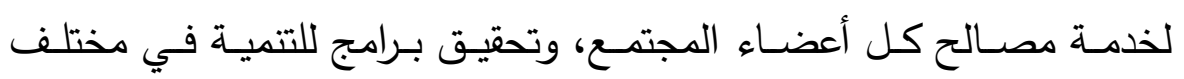
المجالات.

ه- فرض الزكاة وتحريم الربـا: فالزكاة تقرر مبدأ المسئولية والرعاية المتبادلة بين المسلمين، واهتمام بعضهم بمصير بعض؛ فهي قانون عام ولا بد من ضمان لأدائها بكل الوسائل المتاحة، بما في ذلك استخدام القوة إذا لزم الأمر ، كيلا تتحول إلى شأن خاص وتتوقف عن أداء وظيفتها الصحيحة كما هو سائد في لهي الوقت الراهن، كما أن تحريم الربا فيه قضاء على أساليب الحياة الطفيلية. צ- - إقرار الحريات: فقد رسخ الإسلام مبدأ حرية الدين، ورفض أي نوع من الإكراه في مسألة الإيمان والضمير ، سواء كان هذا الإكراه ماديًا أو معنويًا [لَا إِكْرَاهَ الإكراه فِي الآّينِ] $\}$ البقرة:

وفى هذا الصدد لابد من الإشارة إلى نقطة هامة وهي: أن الإسـام لا يقر المذهبية المغلقة ولا سلطة الإكليروس (رجال الدين)، وبالتالي لم ولن يتحول الإسـلام

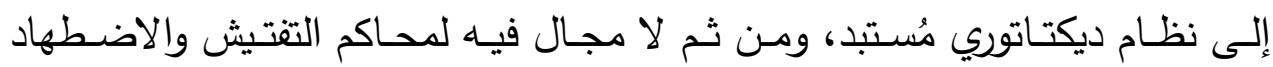
والإرهاب الروحي، وهذا يؤكد على أن للأقليات غير المسلمة في الدول الإسـلامية

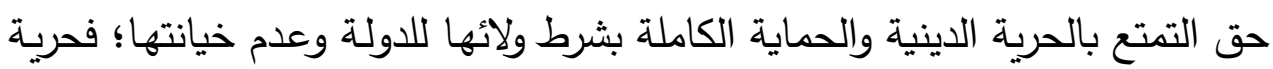
الاعتقاد حق عام في الإسـلام لجميع الناس على اختلاف مللهم ونحلهم من أهل

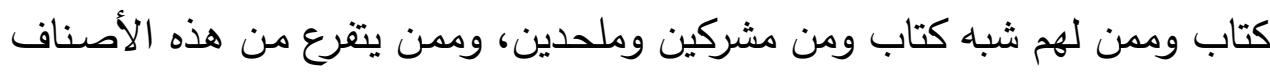

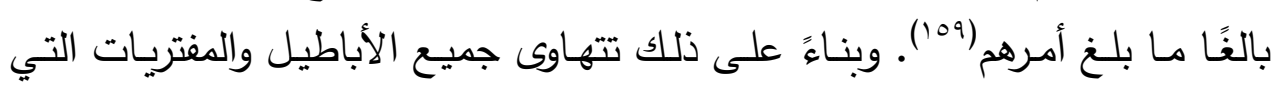


يتقولها أهل الغرب على الجهاد، وما يترتب عليه من فتوحات إسـلامية، حيث إنهم

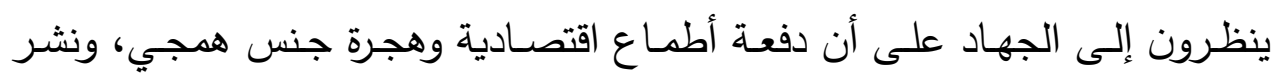

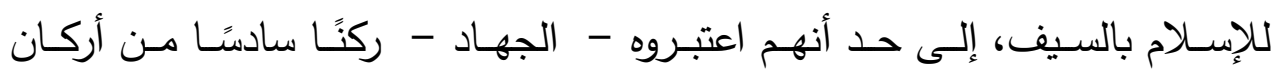

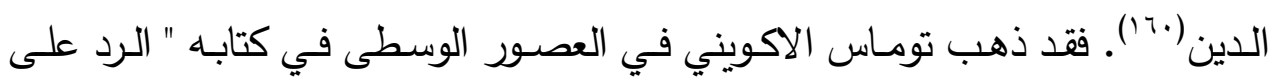

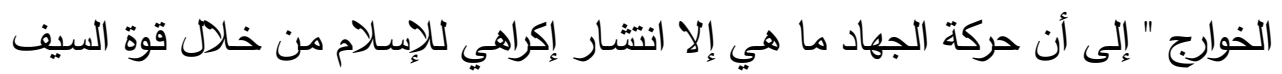

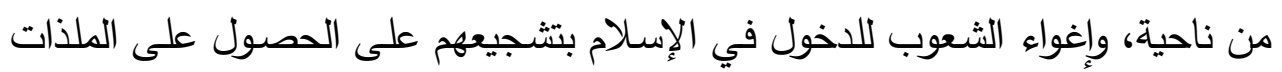

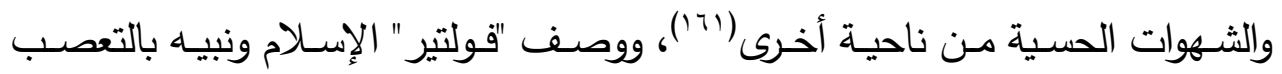
والعنف وحمل السلاح(rآ)، ويذهب "ول ديورانت" إلى أن الحاجة الاقتصادية هي الدافع

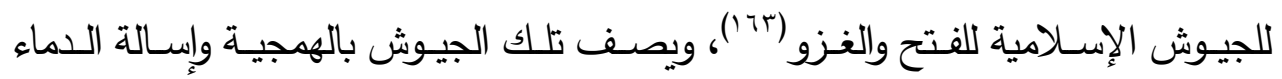
وتحطيم الحضارات(ء؟1)، ويصف "برنارد لويس " الجهاد بالغزو والحرب المقسة (700 (1). وهكذا أصبحت كلمـة الجهـاد لـدى الغـربيين تعنـي شراسـة الطبـع والخلق

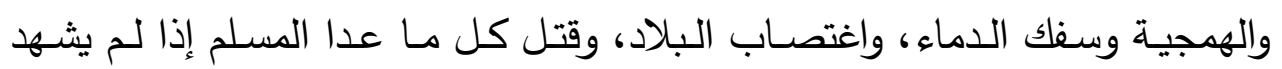

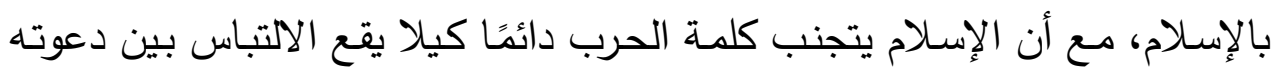

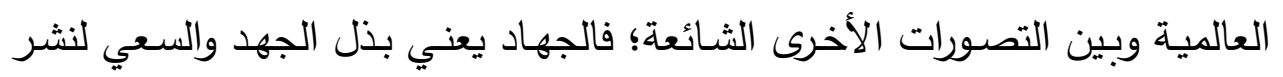

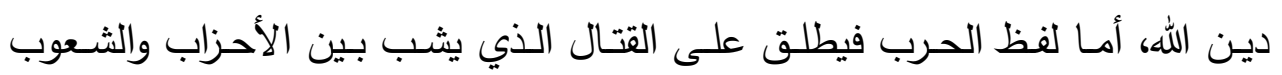
لأهداف وأغراض شخصية واجتماعية واقتصادية.

- V وأخيرًا تكون العلاقات مـع الدول غير الإسـلامية قائمـة على الحريـة الدينية

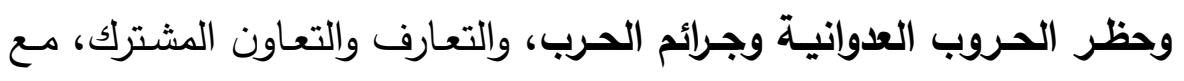

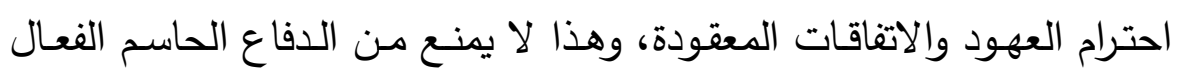

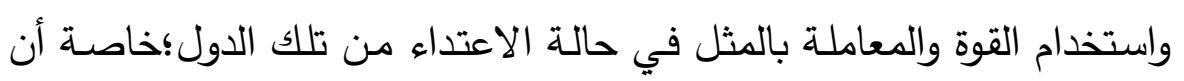

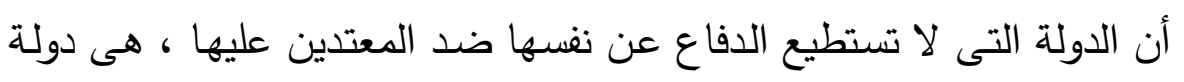

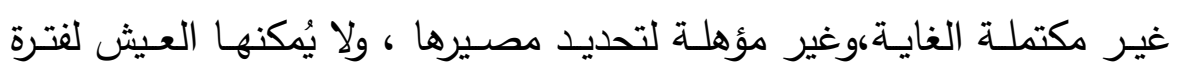

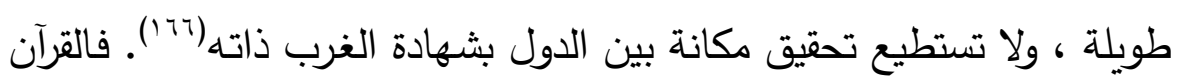

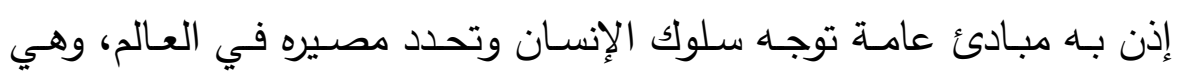


مبادئ دينية وأخلاقية تمثل ثوابت الحياة الإنسانية من حرية ومسئولية ومساواة

$$
\text { وعدالة(1TV). }
$$

\section{خاتمة البحث:}

من خـلال قراءة فكر بيجوفيتش السياسـي عن الثورة والقانون نستطيع أن نلخص النتائج التي تم التوصل إليها في الآتي:

ا- أن الثورة عند بجيوفيتش لم تُختزل في معنى الخروج على النظام السياسي

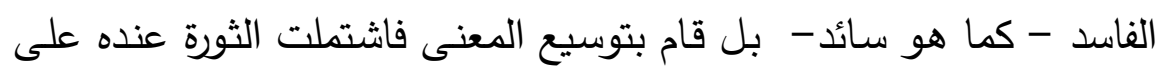
التربية والتعليم والأخلاق كتمهيد ضروري وأساسي لتغيير النظام السياسي؛ فالثورة الحقيقية لا تأتي عن طريق السلطة وإنما عن طريق التربية. ץ- رفض فلسفة الطاعـة بكل صـورها مـع الأجيـال الناشـئة سـواء في البيـ أو المؤسسات التعليمية أو الثارع أو حتى مع أولي الأمر ؛ لأنها فلسفة بئيسة

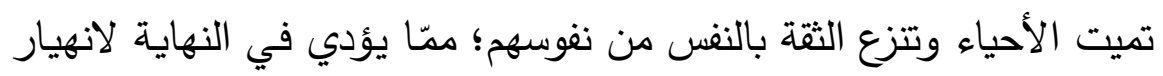
الحضارة الإسلامية.

r- الاهتمام بتغيير وضعية التعليم ووضعية المرأة لتستطيع الثورة أن تأتي بثمارها وتحقق أهدافها.

ع - أن الثورة في العـالم الإســلامي تبـدأ باسـم الـدين وليسـت ضـده - كمـا هـي بالغرب- - لأن مطالب الثورات من حريـة وعدالـة ومسـاواة تتفق مـع طبيعـة الإنة الدين الإسلامي دون أن تصطدم به؛ فالثورة هي التي تحقق مطالب الدين. ه- أن كلًا من التيار المحافظ وتيار الحداثة يمثلان أهم العوائق أمسام الثورة ونجاحها؛ فالأول منعزل عن العالم غارق في الطقوس خادم للسلطة ومنافق لها، والثاني غارق في التغريب لا يستطيع حثد الجماهير لتحقيق برامجه. 
7- إعداد نخبة جديدة لقيادة العالم الإسـلامي، يوحدون بين تراثهم الخاص وبين متطلبات التقدم والتحضر •

- - عدم رفض الغرب كلية بل التأثر به والأخذ منه في العمل والتتظيم والانضباط وأساليب البحوث العلمية والتطور التقني.

^- رفض الثورة المسلحة ضد السلطة الحاكمة؛ لأن ذلك النوع من الثورات ليس لـه جدوى وليس في صـالح الثوار، بسبب تطور السـلاح في العصر الحديث، ومن جانب آخر أن الثورة بالسـلاح تؤدي إلى إزهاق أرواح الآلاف البريئة من الشعب، وأن البديل يكمن في العصيان المدني والمظاهرات العامة. 9- تحديد الوضـع الزمني للقانون لتعم فائدته، حيث إن القانون لا يأتي إلا بعد

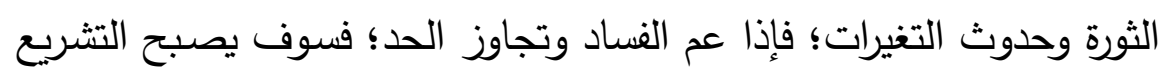

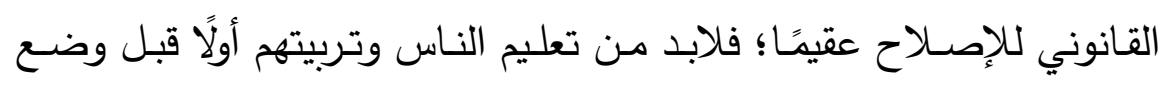
القانون؛ فالقانون يأتي بعد الثورة للحفاظ على مبادئها. • 1- إن النظام الإسلامي هو الحامل الوحيد لثنائية: الحفاظ على الحقوق الطبيعية

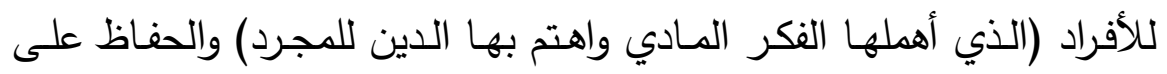
المصـالح المشـتركة للجميـع (الذي أهملهـا الدين المجـرد واهـتم بهـا الفكر (المادي).

\section{المصادر والمراجع}

1- ابن خلدون: المقدمة، ج؟، تحقيق: علي عبدالواحد وافي، القاهرة، دار النهضة، ط؟.

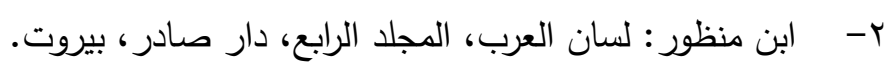

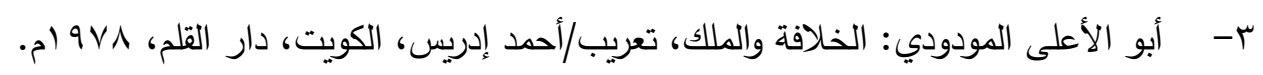
ع - احمد أمين: زعماء الإصلاح في العصر الحديث، القاهرة، الهيئة المصرية العامة للكتاب، .

0- أحمد أمين: ضحى الإسلام، جّا، القاهرة، الكيئة المصرية العامة للكتاب، 1999. 
צ- إليكسي جورافسكي: الإسـلام والمسيحية، ترجمـة: د/خلف حمد الجراد، مراجعة: د/محمود

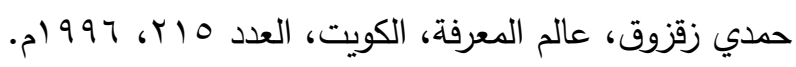
- - أمنية عبدالله سالم: (الثقافة المادية لشعارات حملة تمرد وثورة • ب يونيو تحليل المضمون للشعارات بمواقع التواصل الاجتماعي)، بحث منشور ضمن أعمال المؤتمر الدولي العلمي يوني الثاني بعنـوان: (المجتمـع العربـي وقضـايا التغيير "أفـاق وتطلعـات") بكليـة الآداب جامعـة الفيوم، ع ا • rام، المجلد الثاني.

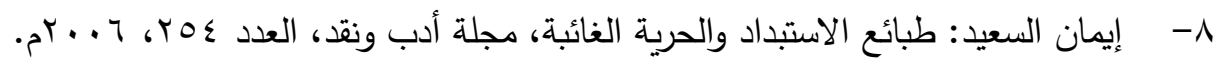
9- برنـارد لـويس: السياسـة والحـرب، ضـمن موسـوعة تـراث الإســلام، ج"، الكويــ، عـالم

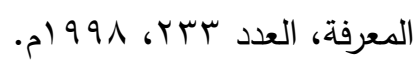
• ا - بيجـوفيتش: الإسـلام بـين الثـرق والغـرب: ترجمـة محمد يوسـف عدس، تقديم عبـدالوهاب

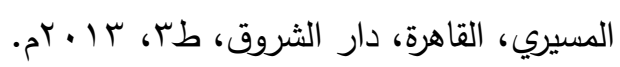
1ا- بيجـوفيتش: الإعلان الإسـلامي، ترجمة وتقديم: محم يوسف عدس، القاهرة، مكتبة الإمـام

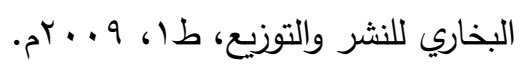
rا - بيجـوفيتش: عوائقق النهضــة الإسـلامية (جـزآن): ترجمـة حسـين عمر سـباهيتش، الـدار

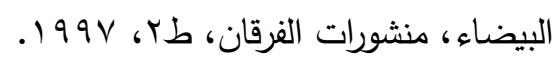
با - بيجـوفيتش: هروبـي إلى الحريـة، ترجمـة إسـاعيل أبو البندورة، مراجعـة د. محم أرنـاؤوط،

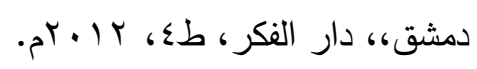

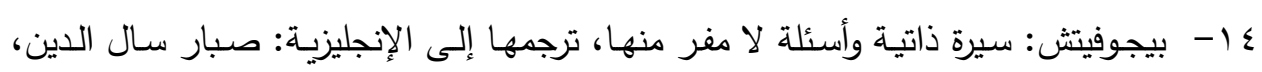

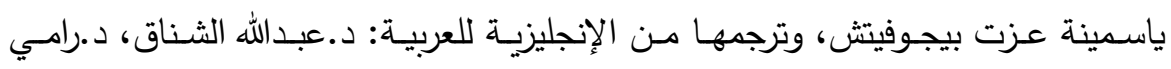

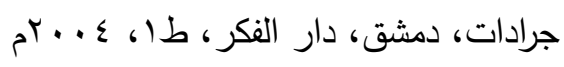
1 - حسن حنفي: هموم الفكر والوطن، جـا، (التراث والعصر والحداثة)، القاهرة، دار المعرفة

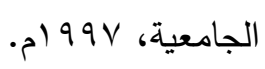
צ ا - حسن حنفي: هموم الفكر والوطن، جـr، (الفكر العربي المعاصر)، القاهرة، دار قباء، .1991

V - V أرندت: في الثورة، ترجمة/عطا عبدالوهاب، مراجعة/رامز بورسلان، بيروت، المنظمة

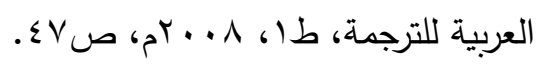




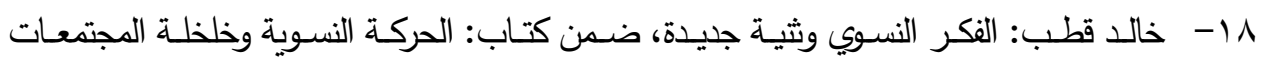

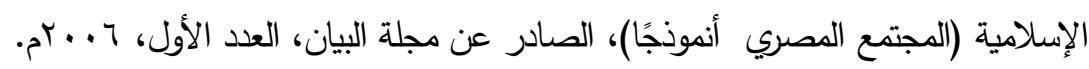

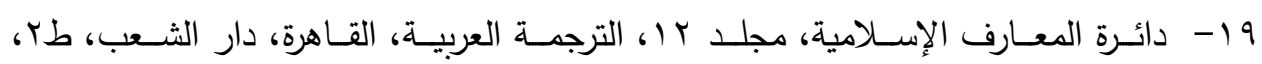
. $) 979$

• ץ- دينيس لويد: فكرة القانون، تعريب/سليم الصـيص، مراجعة/سليم بسيسو، الكويت، عالم

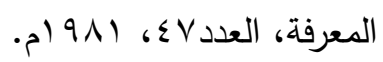

اY- سامي الفريضـي: الرئيس علي عزت بيجوفيتش المفكر المجاهد، دمشق، دار القلم، طاه $\cdot 4 r \cdot 1 r$

r r - عبدالرحمن الكواكبي: طبائع الاستبداد، القاهرة، الهيئة المصرية العامة للكتاب، ب99 ام. سץ- عبدالرحمن الكواكبي: أم القرى، المطبعة المصرية بالأزهر، مبا اهـ/ ابو ام. ـ ז- عبدالمتعال الصـعيدي: حريـة الفكر في الإسـلام، تقديم ححمد صـابر عرب، القاهرة، الهيئة

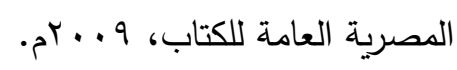

هץ- عزمي بثارة: في الثورة والقابلية للثورة، بيروت، المركز العربي، طץ ا • م.

جr- علي عبدالمعطي ححد: الفكر السياسي الغربي، الإسكندرية، دار المعرفة الجامعية، ا9191. V V - فؤاد زكريا: خطاب إلى العقل العربي، القاهرة، مكتبة مصر، 199. ^ץ- - كـرين بـرينتن: تثـريح الثورة، ترجمة/سـميرالجبلى، مراجعـة د/غـازى بـرو، بيـروت، دار

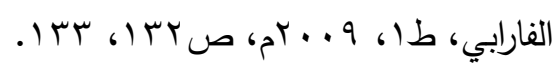

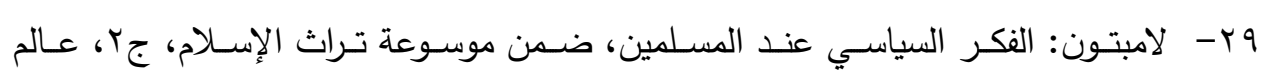

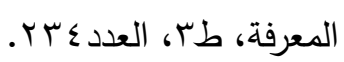

• ץ- محمد جمال الكيلاني: معجم المصسطحات الأرسطية مفهومها ودلالتها، الإسكندرية، دار

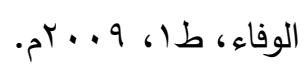

اب- محمد جمال الكيلاني: معجم المصطلحات الأفلاطونية مفهومها ودلالتها، الإسكندرية، دار

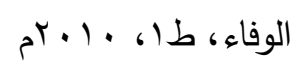

r - نيفين أحمد إسماعيل: تجديد الخطاب الديني بين الثرق والغرب "تحم فريد وجدي، وعلي 
عزت بيجوفيتش "نموذجًا" "، رسالة ماجستير غير منشورة، كلية الآداب، جامعة حلوان. سب- ول ديورانت: قصة الحضارة، المجلد الثاني، ج؟، ترجمة، ذكي نجيب محمود، محه بدران، القاهرة؛ لجنة التأليف والترجمة والنشر .

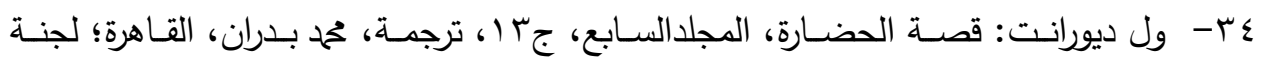

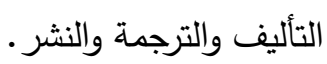




\section{المراجع الأجنيبة}

1. Bastiat,Frederic. The Law ,Translated from the French by Dean Russell ,Foreword by Walter E. Williams , Introduction by Richard Ebeling and Sheldon Richman ,Foundation for Economic EducationIrvington, New York, 1998.

2. ChItty, Joseph. the Law OF Nations, Merriam And Cooke Printers., Sixth American Edition, 1844.

3. Hadeel Al Maaitah, ( etal) . Arab Women and Political Development, Journal of International Women's Studies Vol. 12 , Stockholm, International Institute for Democracy, IDEA, 2005.

4. Isaković, Zehrudin. Muzej Alija Izetbegović, Translation: Saba Risaluddin ,Editor:Elvis Kondžić, Publisher,JU Muzej .2005.

5. kepel ,Gellis. Jiahd: Trial of Political Islam, U K, I.B Tauris Publishers, 2006.

6. Lawrence , Bruce. Shattering the Myth: Islam Beyond Violence, U K, Princeton University press. 1998.

7. Mac Culloch ,Robert. What Makes a Revolution? The Suntory Centre, London, 2001.

8. McLoughlin,Sean. Orientalism and the anthropology of Muslim societies and cultures, Journal of Beliefs \& Values, Vol. 28, No. 3, , pp. 273'296, University of Leeds, UK, December ,2007.

9. Ottaway, Marina. Women's Rights and Democracy in The Arab World, Carnegie Endowment for International Peace, 2004.

10. Rama,Sevita. Remembering their Role: Keeping Women Involved Post-Arab Awakening, , Journal of Women and Human Rights in the Middle East , (pp. 31-45) Issue 1, Fall 2013.

11. Ret ta, Julia. Consequences of the Arab Spring for Women's Political Participation , Journal of Women and Human Rights in the Middle East , (pp. 3-19) Issue 1, Fall 2013.

12. Rule of Law Indicators, Implementation Guide and Project Tools, First edition . Copyright (C) United Nations, 2011. 
13. Satterfield ,Rebecca . An Unfulfilled Promise ? The Role of Women in the Arab Awakening, Journal of Women and Human Rights in the Middle East, (pp. 20- 30) Issue 1, Fall 2013.

(1) Lawrence, Bruce. Shattering the Myth: Islam Beyond Violence, U K, Princeton University press. 1998.p8.

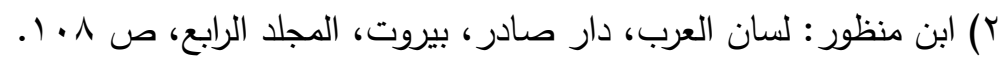

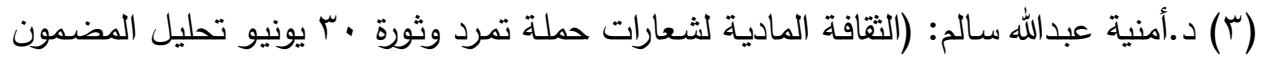

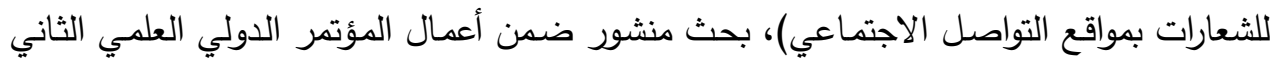

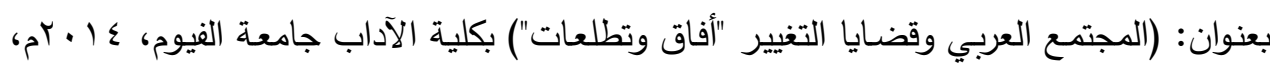

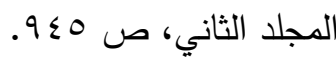

(4) Bastiat,Frederic. The Law ,Translated from the French by Dean Russell ,Foreword by Walter E. Williams , Introduction by Richard Ebeling and Sheldon Richman ,Foundation for Economic EducationIrvington, New York, 1998, pp.2,16.

(5)Mac Culloch ,Robert . What Makes a Revolution ? The Suntory Centre, London ,2001,pp.14,19.

(T) سـامي الفريضسي: الرئيس علي عزت بيجوفيتش المفكر المجاهد، دمشق، دار القلم، طا،

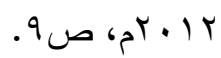

(v) بيجوفيتش: سيرة ذاتية وأسئلة لا مفر منها، ترجمها إلى الإنجليزية: صبار سال الدين، ياسمينة

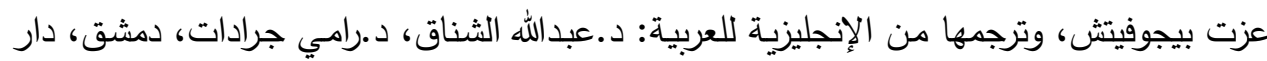

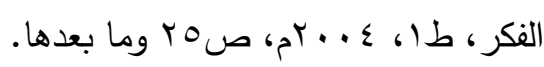

(8)Isaković, Zehrudin. Muzej Alija Izetbegović, Translation:Saba

Risaluddin ,Editor:Elvis Kondžić, Publisher,JU Muzej .2005.p, 15,35.

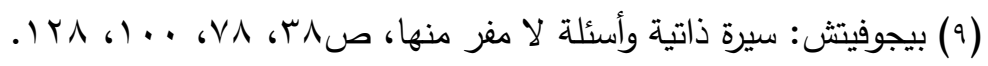

(10) kepel ,Gellis. Jiahd: Trial of Political Islam, , U K , I.B Tauris Publishers,2006.p.245.

(1') بيجوفيتش: الإعـلان الإسـلامي، ترجمـة وتقديم: محمد يوسف عدس، القـاهرة، مكتبـة الإمـام

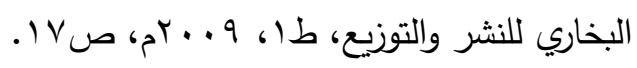

(12) jiahd: Trial of Political Islam.p.254.

$$
\begin{aligned}
& \text { (r) حول تلك الأحداث بالتفصيل راجع: الإعلان الإسـلامي، ص V ا وما بعدها وكذلك سامي }
\end{aligned}
$$

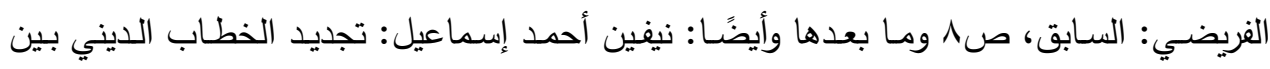


الشرق والغرب "حمح فريد وجدي، وعلي عزت بيجوفيتش "نموذجا" "، رسالة ماجستير غير منشورة،

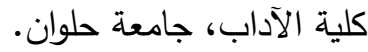

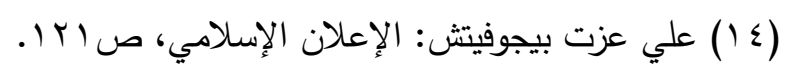

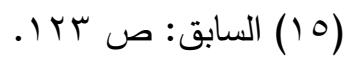

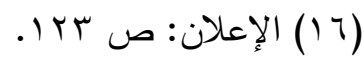

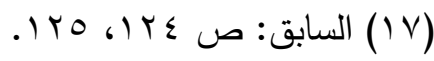

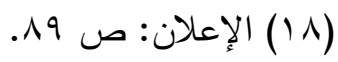

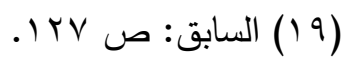

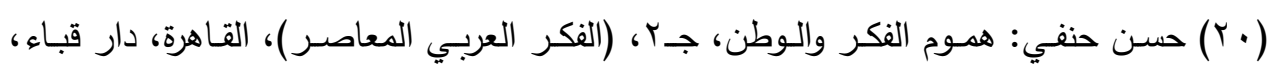

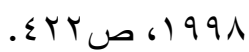

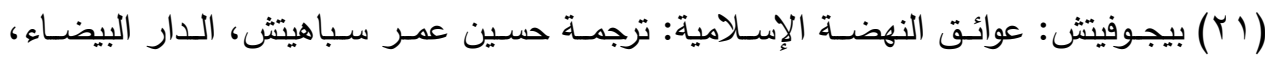

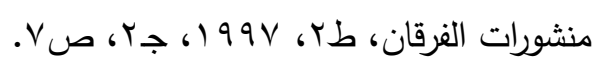

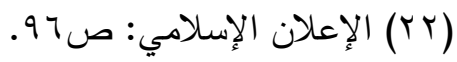

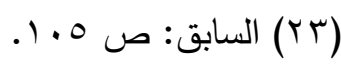

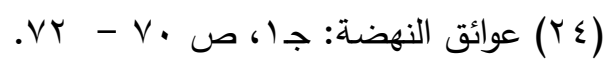

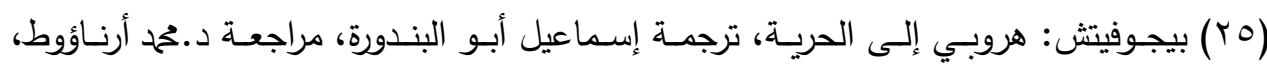

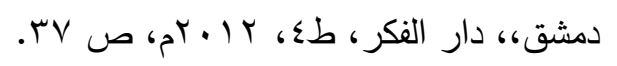

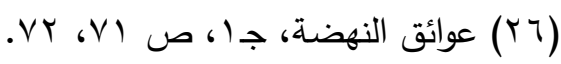

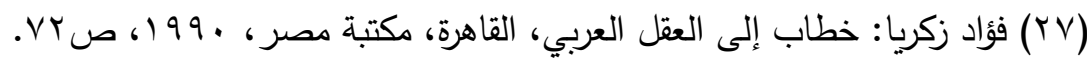

$$
\text { (YN) }
$$

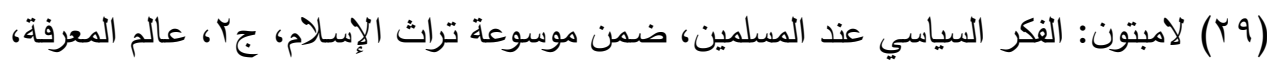

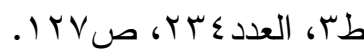

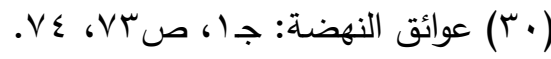

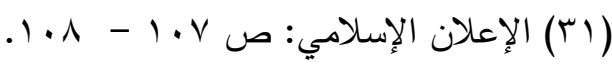

(32) Mac Culloch ,Robert. What Makes a Revolution ? The Suntory Centre , London ,2001, " Introduction".

(33)Rule of Law Indicators , Implementation Guide and Project Tools ,First edition . Copyright () United Nations, 2011,pp.13.

(34) What Makes a Revolution ?pp.7,16. 


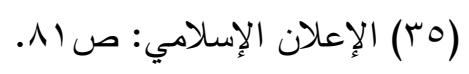

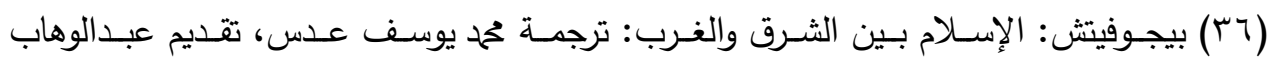

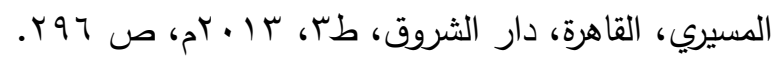

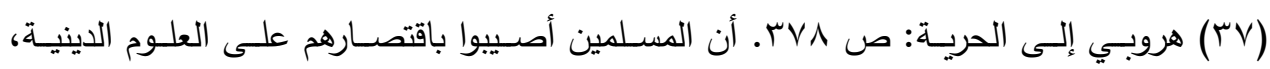

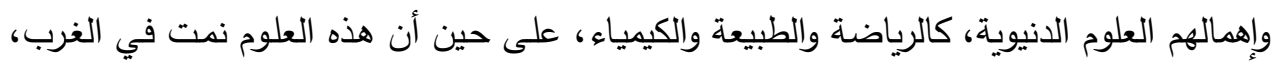

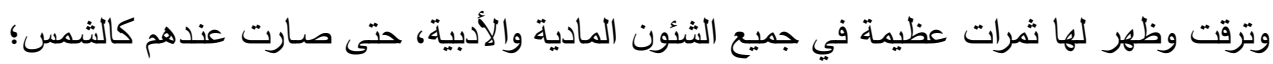

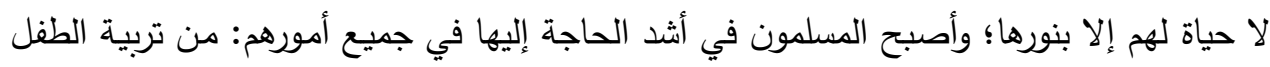

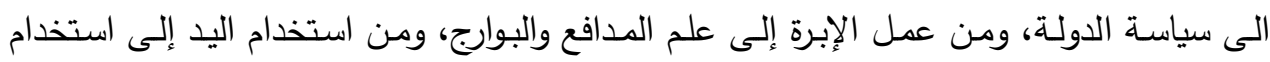

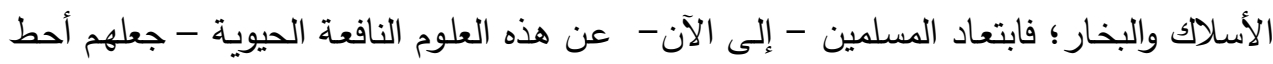

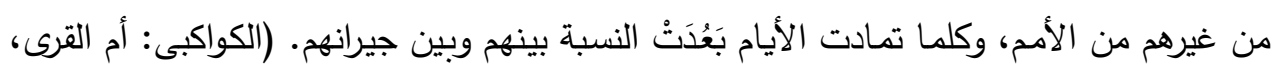

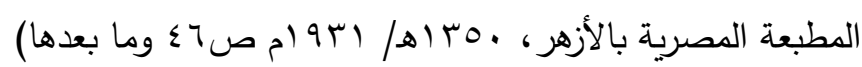

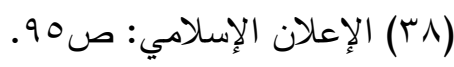

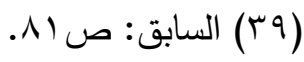

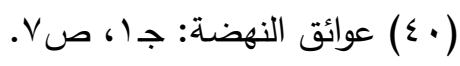

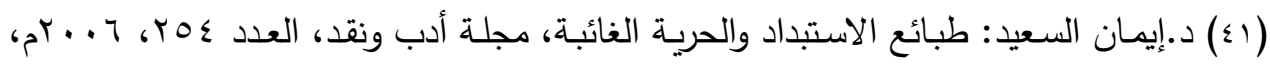
ص זד.

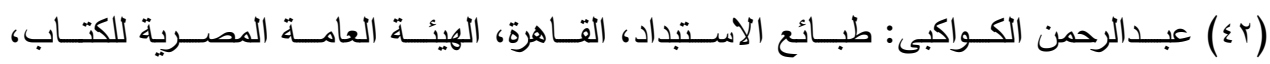
صسז:

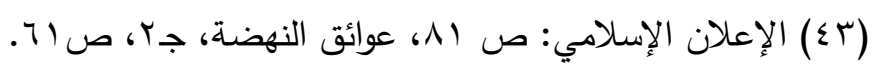
( ) ( السابق: جr ( ( السابق: جr)

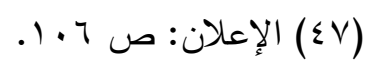

(48) Lawrence , Bruce. Shattering the Myth: Islam Beyond Violence,p.8.

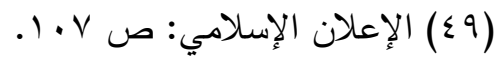

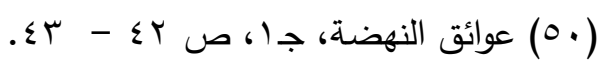

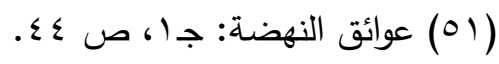

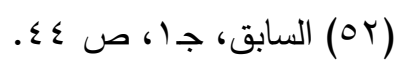


(53) Satterfield ,Rebecca . An Unfulfilled Promise? The Role of Women in the Arab Awakening, Journal of Women and Human Rights in the Middle East , Issue 1, Fall 2013,p.27.

(54)Ottaway, Marina. Women's Rights and Democracy in The Arab World, Carnegie Endowment for International Peace, , 2004 ,pp.4,5.

(55) Hadeel Al Maaitah, ( etal) . Arab Women and Political Development ,Journal of International Women's Studies Vol. 12 , Stockholm, International Institute for Democracy, IDEA, 2005, pp.8,9,19.

(56)Ottaway, Marina. Women's Rights and Democracy in The Arab World,p.11.

$$
\begin{aligned}
& \text { (OV) الإعلان الإسلامي: ص س (OV) }
\end{aligned}
$$

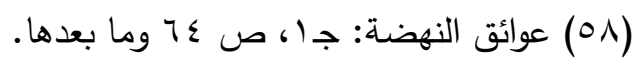

$$
\begin{aligned}
& \text { (09) السابق: جا ، ص سٓع. }
\end{aligned}
$$

(60) Satterfield ,Rebecca . An Unfulfilled Promise ?p.22.

(61) Hadeel Al Maaitah, (etal) . Arab Women and Political Development, p.7.

$$
\begin{aligned}
& \text { (T) الإعلان الإسلامي: ص r III. }
\end{aligned}
$$

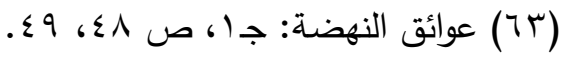

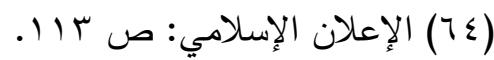

(65) Retta ,Julia . Consequences of the Arab Spring for Women's Political Participation , Journal of Women and Human Rights in the Middle East , Issue 1, Fall 2013, pp. 3,16.

(66) Ottaway, Marina. Women's Rights and Democracy in The Arab World, ,p.6

$$
\text { (TV) عوائق النهضة، ج) (TV) }
$$

(68) Retta ,Julia . Consequences of the Arab Spring for Women's Political Participation ,pp.3,15.

$$
\begin{aligned}
& \text { (79) عوائق النهضة: جا ص (7. } \\
& \text { (V) (V) السابق: نفس الصفحة. }
\end{aligned}
$$

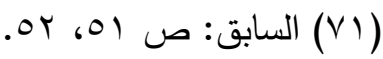

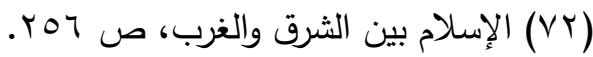

(73) Rama,Sevita. Remembering their Role: Keeping Women Involved Post-Arab Awakening, , Journal of Women and Human Rights in the Middle East Issue 1, Fall 2013 , p.31. 


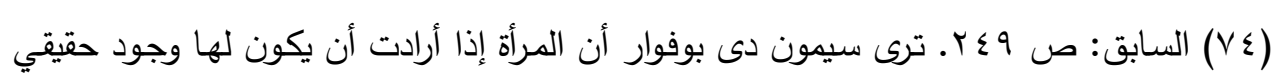

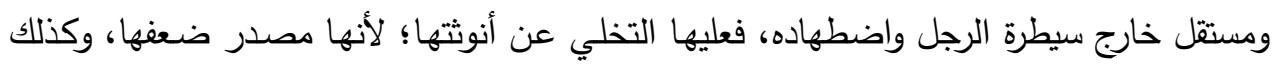

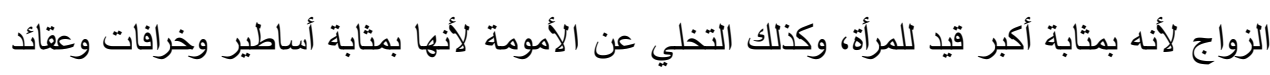

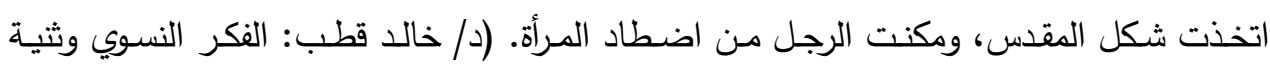

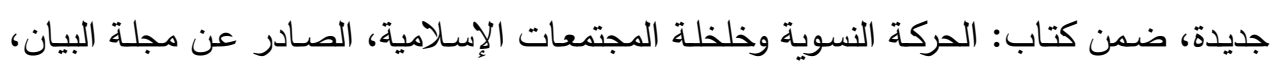

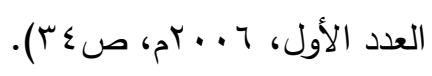

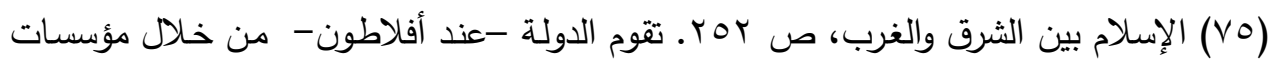

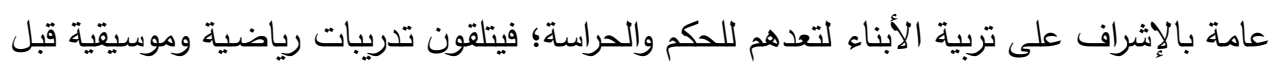
سن العشرين، ثم يتلقون التدريب العسكري ودراسة الحساب =والهندسة والفلك حتى سن الثناء الثلاثين،

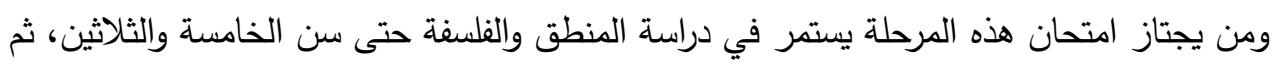

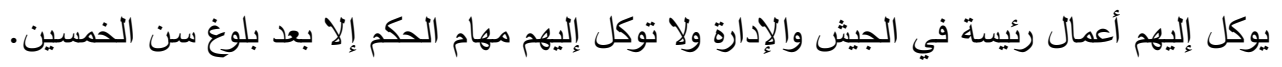

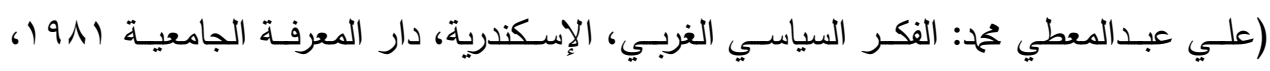
صد (VT)

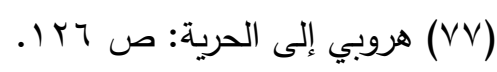
(VA)

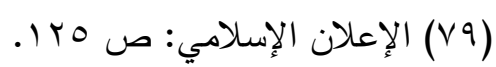

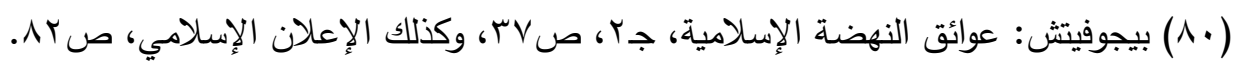

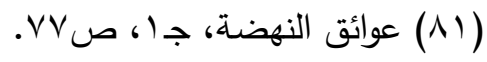

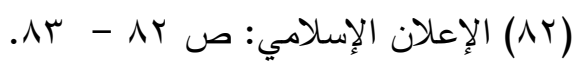

(83)Isaković , Zehrudin. Muzej Alija Izetbegović,p, 16.

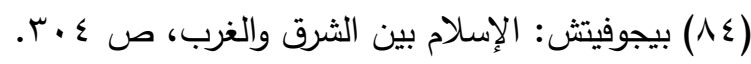

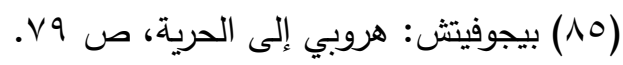

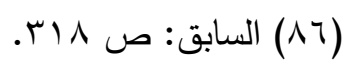

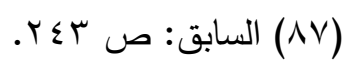

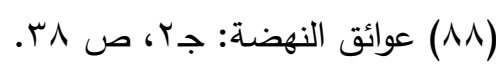

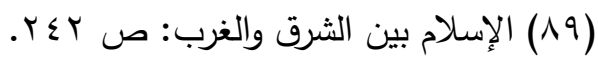


(9) كرين بـرينتن: تثـريح الثورة، ترجمة/سمير الجبلى، مراجعـة د/غـازى بـرو، بيـروت، دار

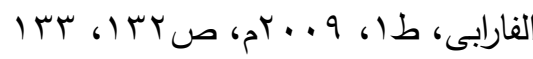

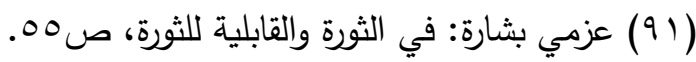

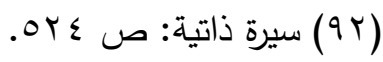

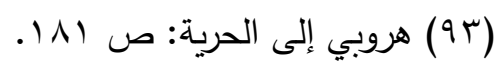

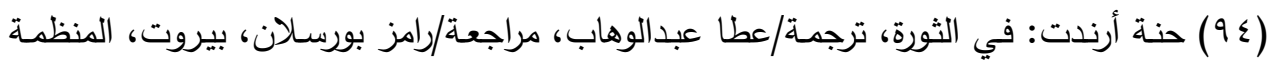

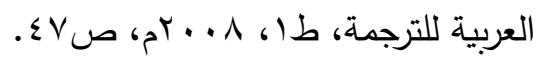

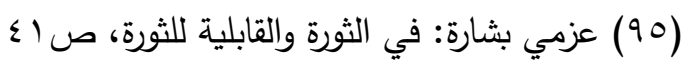

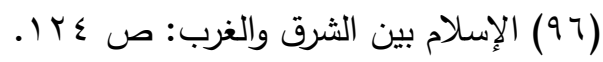

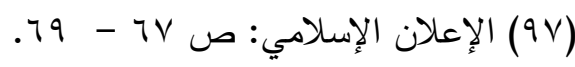

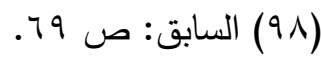

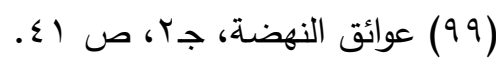

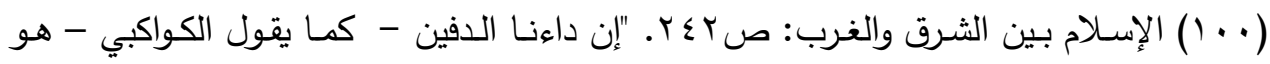

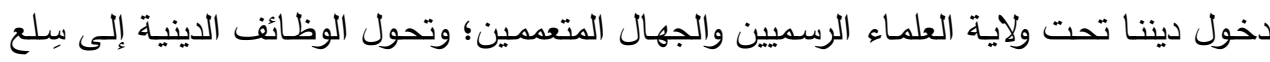

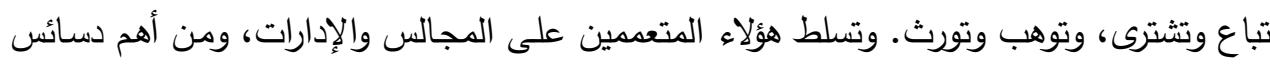

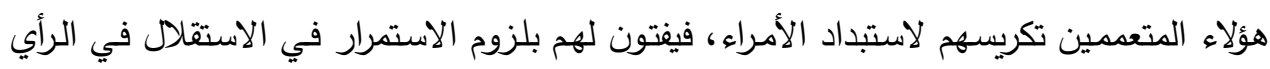

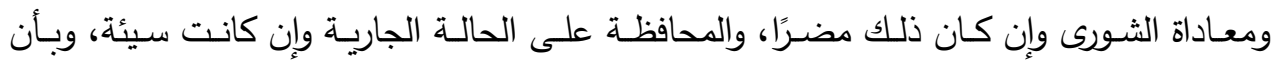

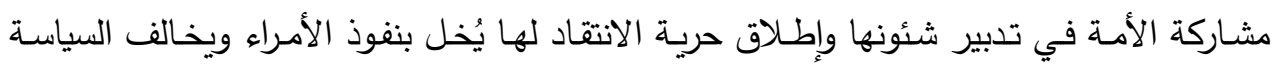

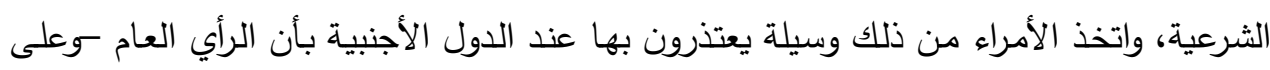

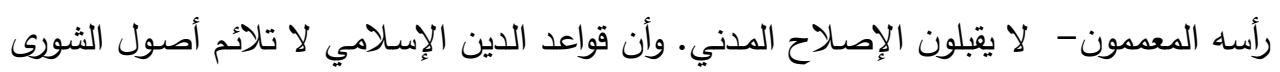

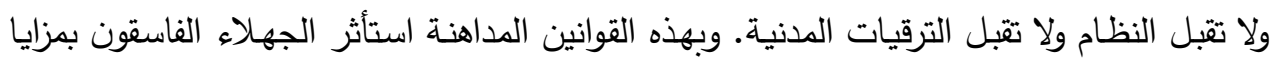

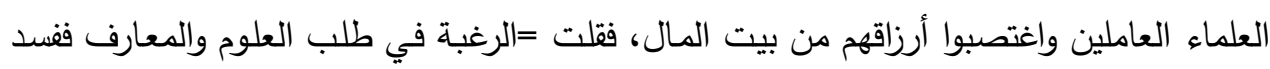
العلم وقل أهله، فاختلت التربية الدينية في الأمة فوقعت في الفتور وكثرت فيها الثرورد" (الكواكبى:

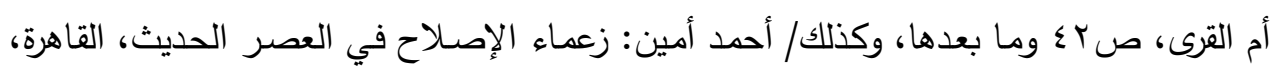

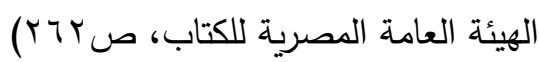

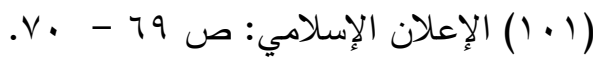

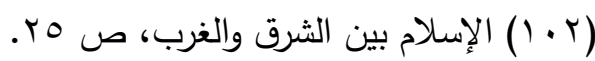

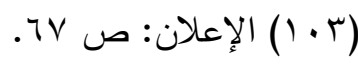




$$
\begin{aligned}
& \text { ( ) • (1) السابق: ص • V. }
\end{aligned}
$$

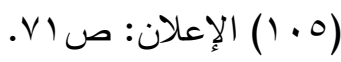

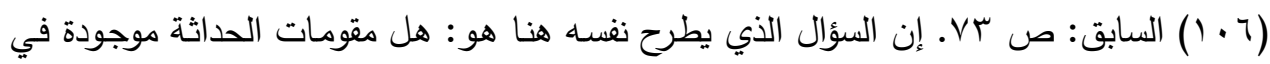

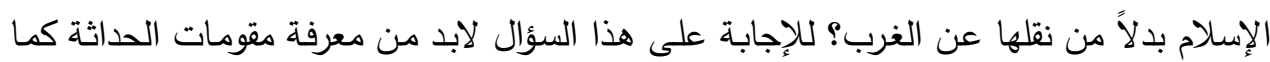
يبغيها علماء الاجتماع والسياسـة أو منظرو الحداثة بصفة عامـة؛ فالحداثة عندهم هي مجموعة الإنة

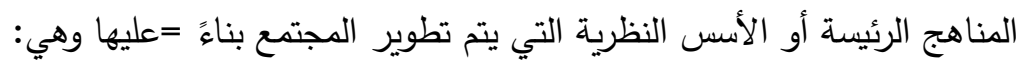

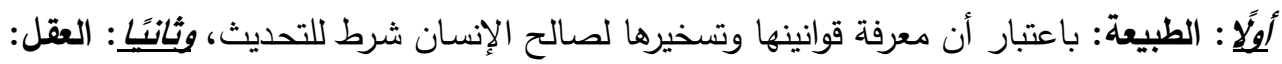

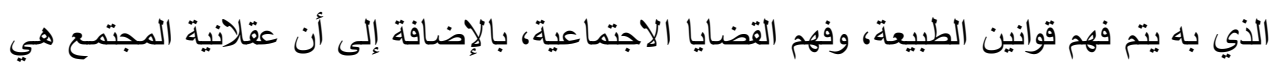

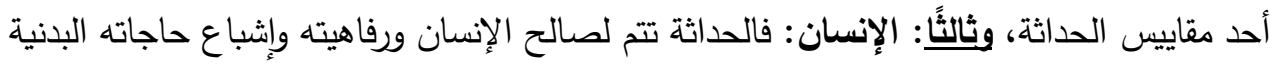

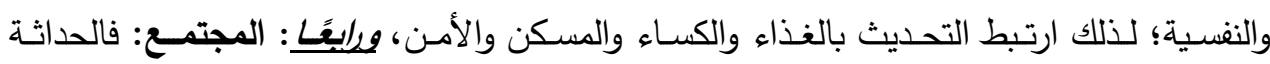

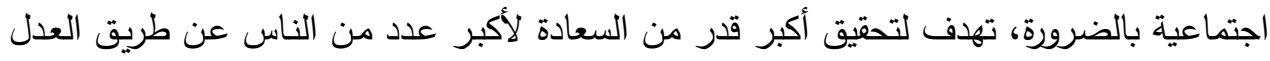

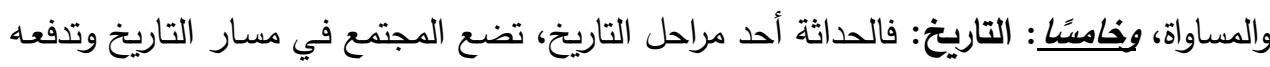

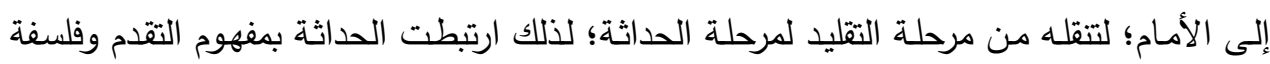
التقدم الفكري والمـادي. (حسن حنفي: هـوم الفكر والوطن، جـا ، (التراث والعصر والحداثة)،

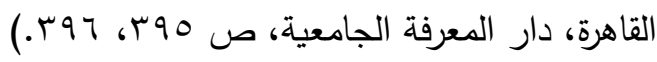

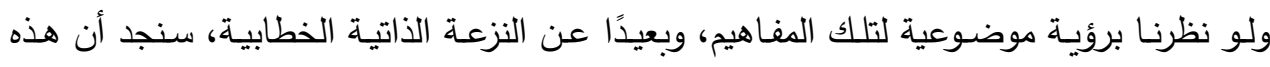
الدفاهيم موجودة في الإسـلام سواء في أصوله أو في علومـه؛ فالقرآن يصور الطبيعسة والإنسان

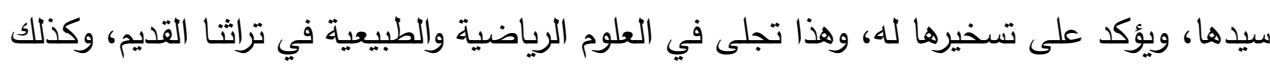

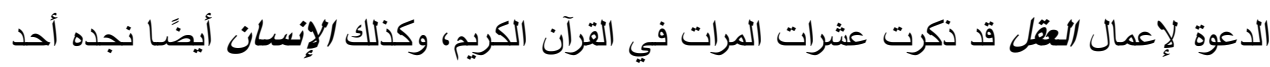

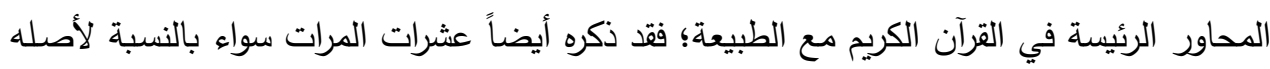

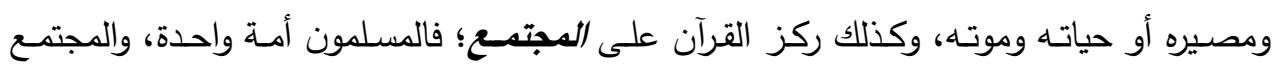

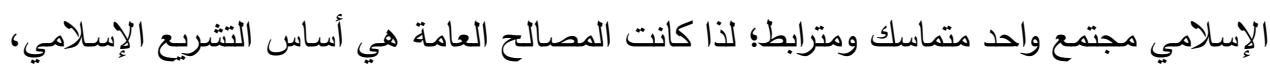

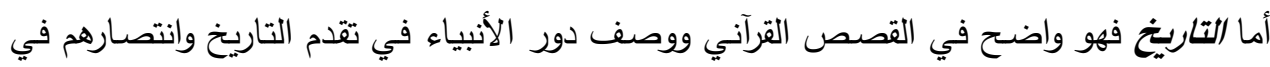

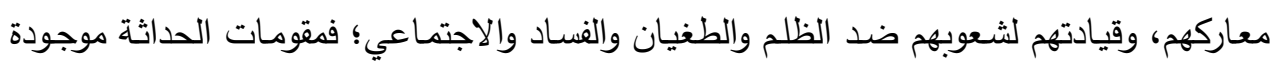

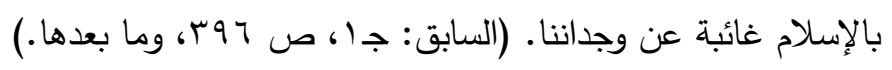

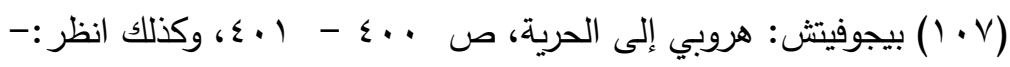

Isaković, Zehrudin. Muzej Alija Izetbegović,. P, 19 . 


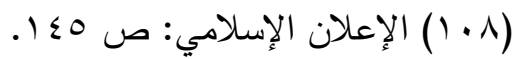

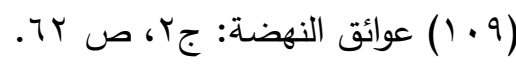

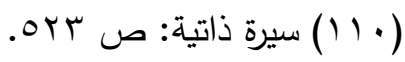

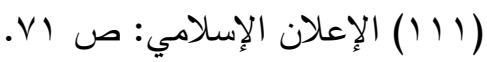

(112) shattering the Myth: Islam Beyond Violence.p.82.

$$
\begin{aligned}
& \text { (1, (1) الإعلان: ص (1) }
\end{aligned}
$$

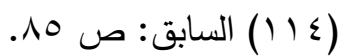

(10 10 ) حسن حنفي: هموم الفكر والوطن، جـا، (التراث والعصر والحداثة)، القاهرة، دار المعرفة

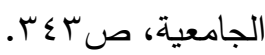

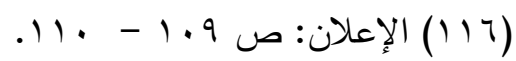

$$
\begin{aligned}
& \text { (liv) }
\end{aligned}
$$

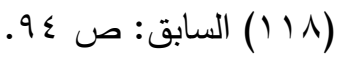

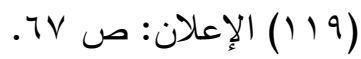

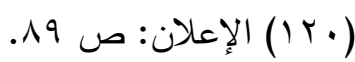

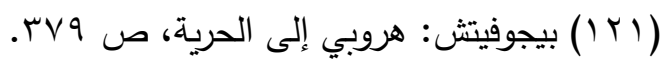

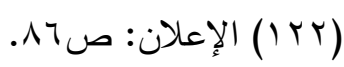

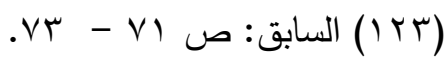

(124) ChItty, Joseph. the Law OF Nations, Merriam And Cooke Printers., Sixth American Edition, 1844.pp.77, 232.

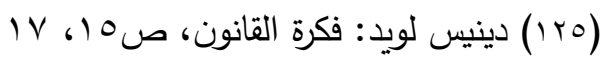
(ד Y ( ) د. دينيس لويد: فكرة القانون، تعريب/سليم الصويص، مراجعة/سليم بسيسو، الكويت، عالم

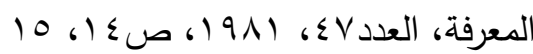
( IVV) لأنسه ليس هنالك قانون أو شرعية أعظم من المعرفة شـأنًا، فرفض خضوع الحاكم الفيلسوف إلى دهى قوانين مستمدة من العرف والعادات والتقاليد؛ واستبدل القانون بحكم الفلاسفة، فهم وحدهم القادرون على فهم الخير وتحقيقة للمجتمع (كحا جمال الكيلانسى: معجم المصطلحات الأفلاطونية مفهومها

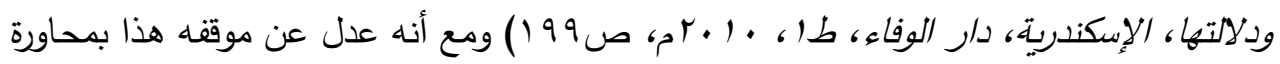

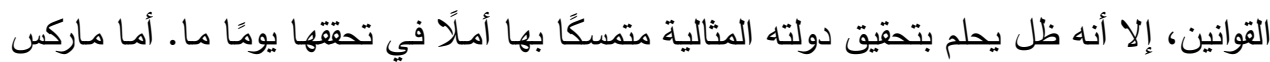


فكان يعتبر القانون مجرد نظام قمعي للحفاظ على امتياز طبقة الملاك، وأن الثورة ستؤدي لقيام مجتمع لا طبقي، وستلغى فكرة القانون (دينسيس لويد: فكرة القانون، ص ابل)، والحق أن القانون عقل مجرد عن الهوى؛ كما يقول أرسطو فأرشد الحكام لا يمكنه الاستغناء عن القانون(محا جمال

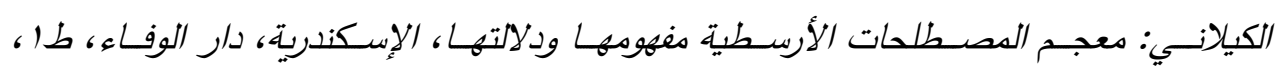
$\cdot($ مr... 9

(128) Rule of Law Indicators , pp.6,7.

(129) Rule of Law Indicators. P.67.

(130)Bastiat,Frederic. The Law ,p.80.

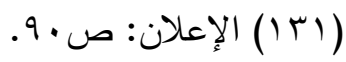

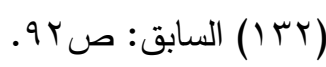

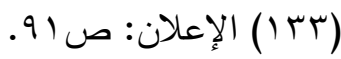

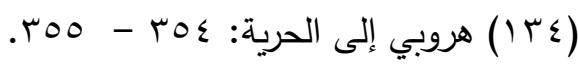

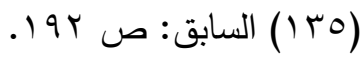

$$
\begin{aligned}
& \text { (דr ا (الإسلام بين الثرق والغرب: ص ع اس. }
\end{aligned}
$$

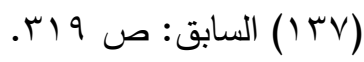

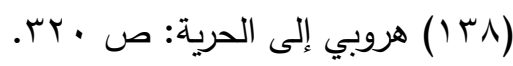

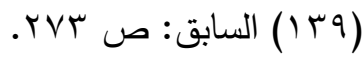

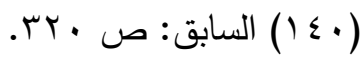

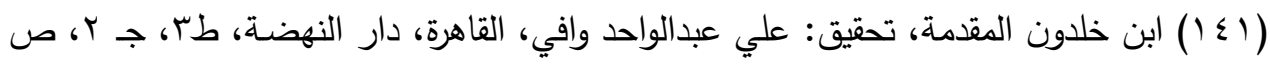

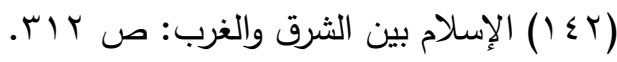

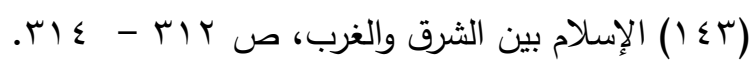

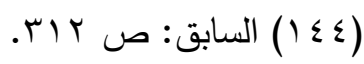

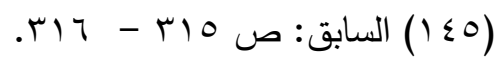

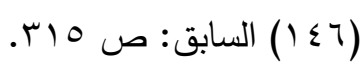

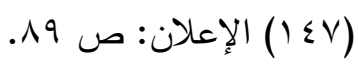

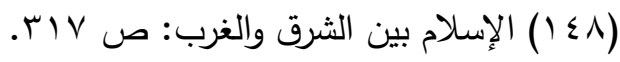

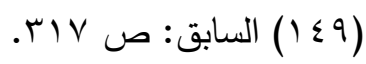


(150) McLoughlin,Sean. Orientalism and the anthropology of Muslim societies and cultures, Journal of Beliefs \& Values, Vol. 28, No. 3, , pp. 273'296, University of Leeds, UK , December ,2007,p.283.

$$
\begin{aligned}
& \text { (101) الإعلان: ص } 91 \text { (1019. }
\end{aligned}
$$

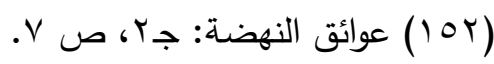

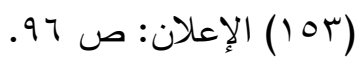

$$
\begin{aligned}
& \text { (10 (1) الإعلان الإسلامي، ص الإعلان } 97 \text { (10) وما بعدها. }
\end{aligned}
$$

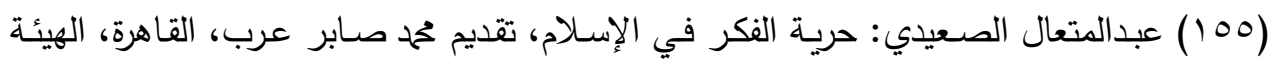

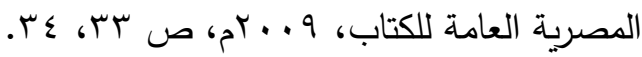

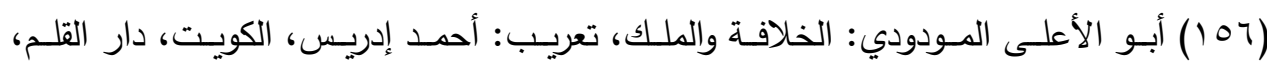

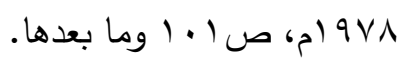

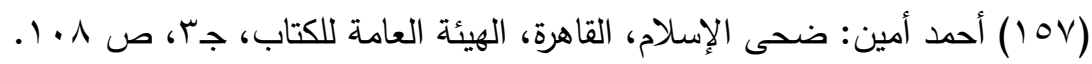
(158) Shattering the Myth: Islam Beyond Violence.p.18.

(109) (109) عبدالمتعال الصعيدي: السابق، ص الم. وكذلك انظر :

McLoughlin,Sean. Orientalism and the anthropology of Muslim societies and cultures,p.284 .

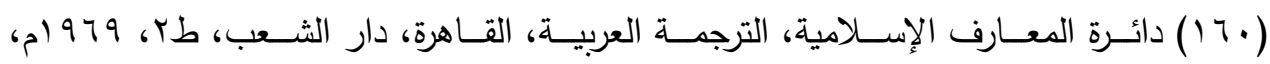

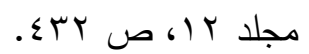

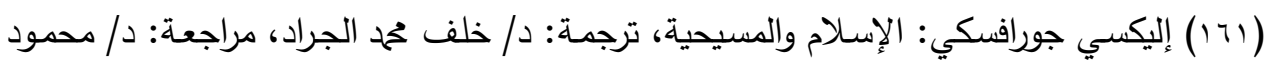

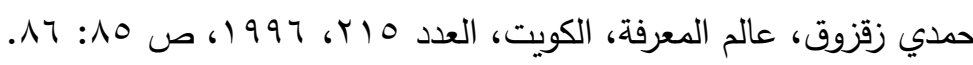

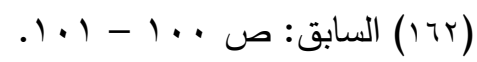

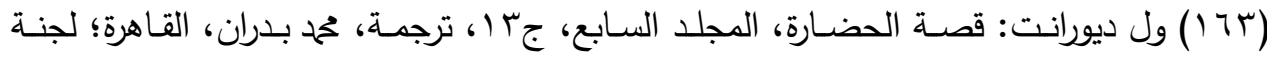

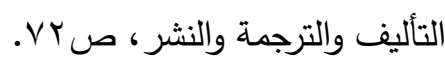
(ع 11) ول ديورانت: قصة الحضارة: المجلد الثاني، ج؟َ، ترجمة، ذكي نجيب محمود، محمد بدران،

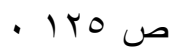
(170) برنارد لويس: السياسة والحرب، ضمن موسوعة تراث الإسلام، ج؟، الكويت، عالم المعرفة،

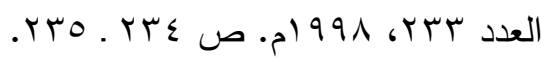

(166) the Law OF Nations .p.87. 


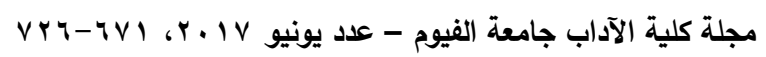

أشرف أمين

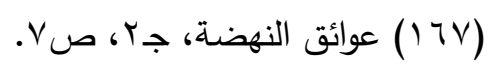

